\title{
THE FEAST OF POKROV, ITS BYZANTINE ORIGIN, AND THE CULT OF GREGORY THE ILLUMINATOR AND ISAAC THE PARTHIAN (SAHAK PART ${ }^{\mathrm{C}}$ EV) IN BYZANTIUM
}

In the following paper I will try to show that the feast of Pokrov emerged from Armenian traditions in Byzantium and is preserved in Byzantine traditions in Russia. Thus, the article contains two major parts, "Byzantino-Slavica" and "Armeno-Byzantina," with a third section as a kind of conclusion.

The cult of St Gregory the Illuminator in Byzantium from the middle of the ninth to the early tenth century and its role in the ideology of the Macedonian dynasty and its earlier background is another main subject of the following study. ${ }^{1}$

\section{Part One: Byzantino-Slavica}

\subsection{Introduction}

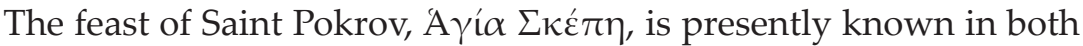
Russian and Greek liturgical traditions, but the Greek service appeared in the nineteenth century as a translation from Russian Slavonic. ${ }^{2}$ The feast of Pokrov seems to be completely unknown to the Byzantine rite. ${ }^{3}$ This is not to say that it was never known there. The

(1) This paper is dedicated to the memory of Michail Fëdorovich Murianov (1928-1996), whose articles opened to me the Byzantine background of the early Russian liturgy, and Karen Nikitich Youzbashian (1927-2009), who introduced me to the world of Armenian studies and to the twists and turns of Armeno-Byzantine relations under Photius and in the Macedonian period.

(2) Wortley 1971, 149-151. See the list of abbreviations at the end of the article.

(3) In 1682, the Moscow correctors of the Russian liturgical books stated that they found nothing of the service for Pokrov in the Greek liturgical books. Cf. А. А. Дмитриєвский, Праздник в честь Покрова Пресвятой Богороди- 
Russian tradition - that is, the tradition of the Church and its hagiographical documents - insists that, quite to the contrary, the feast was established in Constantinople and was accepted in Russia, which was part of the Constantinopolitan patriarchate. There is, however, another Russian tradition, a scholarly one that begins in the late nineteenth century. This tradition insists that the feast is of Russian origin and was established either in Kiev (Sergij Spasskij 1898) ${ }^{4}$ or Vladimir (Medvedeva and Voronin, in the late 1940s) ${ }^{5}$ or Novgorod (Yusov 2009) somewhere in the pre-Mongolian period (before 1237). According to this viewpoint, the evidence of the feast's Byzantine origins that is found in documents from the Russian Church is not to be taken at face value because it represents nothing more than the requisite claims of authority. Of course there are other opinions, even among the Russian scholars. I will mention some of them below.

The hypothesis of a Vladimir origin of the feast is the most popular among Soviet and post-Soviet scholars. It was refuted in detail by Mariia Pliukhanova already in $1995^{6}$ but it is still maintained by some scholars, although without any answer to Pliukhanova's criticisms. ${ }^{7}$ For some Russian scholars this hypothesis has been transformed into

цы и величание для него [А. А. DмiтrievsкiJ, The Feast in Honour of the Pokrov of the Most Holy Theotokos and the Megalinarion for it], Pуководcтво для сельских пастырей [Guidance for Village Priests (Kiev)] (1885) № 46, 311-316, here 312-313.

(4) SpAssKij 1898.

(5) The idea has been mentioned since the nineteenth century. At that time, Ostroumov published his supposition in a non-scholarly Church review in 1911 [М. А. Остроумов, Происхождение праздника Покрова <The Origin of the Feast of Pokrov>, Приходское чтение <Parish Reading $>$ (St Petersburg) (1911) Nr 19. 401-412]. His paper was a work of journalism rather than scholarship. His claim was then substantiated by N. N. Voronin and his disciple E. S. Medvedeva, first in the latter's thesis (unpublished but widely quoted by Russian art historians to the present): Е. С. МЕдВЕдЕВА, Этюды о суздальских spamax [Essays on the Suzdal Gates]. Диссертация на соискание ученой степени кандидата искусствоведения (Moscow, 1947) (unavailable to me). Cf. Voronin's summarizing paper: Н. Н. Воронин, Из истории русско-византийской церковной борьбы XII в. II. Праздник Покрова [From the History of the Russo-Byzantine Church Struggle in the Twelfth Century. II. The Feast of Pokrov], BB 26 (1965) 208-218.

(6) М. Плюханова, Сюжеты и символь Московского Царства [The Themes and Symbols of the Muscovite Tsardom] (St Petersburg, 1995) 52-59.

(7) Loseva 2009, 130. 
a "dogma of creation of the feast of Pokrov by Andrew of Bogolubovo [prince of Vladimir from 1157 to 1174]" (as Pliukhanova put it ${ }^{8}$ ), opening the way to further far-reaching claims. ${ }^{9}$ Perhaps this dogma retains its popularity because it provides a handy legend to explain the origin of the most beautiful representative of Old Russian architecture, the church of an unknown original dedication established in the twelfth century near Vladimir, on the river Nerl. This church is mentioned in much later sources, and, more important, in modern guidebooks, as dedicated to Pokrov.

The hypothesis of Novgorodian origin is the most recent to appear. It is based on the fact that the earliest documented appearance of certain relevant data is in documents and artefacts of Novgorodian origin. It is corroborated by a specific cult of St Andrew in Novgorod, where Andrew's Slavic origin (the "Scythian" of the Greek original was rendered as "Slav" in Slavonic versions) is interpreted as "Novgorodian," and by an affinity between the cult of Pokrov and a purely Novgoro-

(8) “Догма о создании праздника Покрова Андреем Боголюбским" (Pliukhanova 2008, 441, n. 10) in Moldovan 2000, 106, 116-117.

(9) For instance, Moldovan 2000, 106-115: the distribution of the fragments of the Life of Andrew the Salos in the Russian Synaxarium (Prolog), where the first fragment, on 1 October, is considered to be edited much later than the remaining seven fragments (on 2, 3, 4, 5, 8, 12, and 16 October). Moldovan accepts Fet's dating of the first (short) recension of the Prolog to the first half of the twelfth century (Moldovan 2000,106), but this earlier date is unacceptable to him for the entry on Pokrov on 1 October, which he believes to have been written by prince Andrew of Bogolubovo (Moldovan 2000, 116). However, see LosEva 2009, 80-128, on the wider range of possible dating of both the short and long recensions of the Prolog, and her observations concerning the inadequacy of Moldovan's identification of the Prolog recension of the Life of Andrew the Salos (Loseva 2009, 131). In sum, so far we know nothing certain about the recension of the Life of Andrew used in the Prolog entry on Pokrov on 1 October. Another example of a far-reaching conclusion from the "dogma of Andrew of Boglubovo" is presented by Loseva herself when she concludes from the fact of the presence of the commemoration of Pokrov in the menologium of a Serbian Gospel of the second quarter of the thirteenth century (Vatican, Slavo. 4) that this is a witness of "the direct links of Vladimir-Suzdal Rus' with Serbia (о непосредственных связях Владимиро-Суздальской Руси с Сербией)” in this period; O. В. Лосева, Русские месяиесловы XI-XIV вв. [The Russian Menologia of the eleventh-fourteenth centuries] (Moscow, 2001) 108. In fact, this is only a witness of some links between Serbia and Rus' but not anything specific about Vladimir and Suzdal. 
dian cult of the icon of Theotokos Znamenie (Holy Sign). ${ }^{10}$ These facts can be explained in a more economical way by supposing that the two different Old Russian Pokrov traditions, from Vladimir-Suzdal and from Novgorod, both go back to a common source.

The hypothesis of Kievan origin remains the best supported among the "Russian" hypotheses. No wonder. Its author, Archbishop Sergij Spasskij (1830-1904), whose "Complete Menologion of the East" (Полный месяцеслов Востока, 1875-1876) is known by every specialist in hagiography, was the only person among the partisans of the "Russian" view who dealt with hagiographic matters and paid attention to their proper nature, that is, he did not approach the issue as an ordinary historian or philologist. Thus, many scholars agree with Spasskij that the only real alternatives are either Constantinople or Kiev. I, too, share this approach.

Spasskij's argument was based, first of all, on the history of the Russian Prolog, where the commemoration of Pokrov appears in the earliest manuscripts, and second, his thesis was based on the service of the feast. Although many details in his construction have been corrected and changed, the logic of his overall thesis has not been altered. ${ }^{11}$ However, these reconsiderations seem not to affect very much his logical construction as a whole. Spasskij's most important claim was in his conclusion that such a total acceptance of the feast throughout all the Russian lands is natural only if the feast had been established by the central Kievan authorities. In fact, even Voronin's Vladimir hypothesis was nothing more than a modification of the same conclusion, ascribing the central authority not to Kiev but to the Vladimir of Prince Andrew (an approach that is unacceptable especially from the point of view of Church history, as Pliukhanova demonstrated).

Thus, I see no reason to abandon Spasskij's conclusion that the feast of Pokrov was established for the whole Russian Church in Kiev. There are some reasons, however, not to accept his view that the feast was created in Kiev as well.

(10) See Yusov 2009, 37-38, cf. 55-65. Yusof considers this hypothesis as the most plausible but not proven.

(11) See especially Loseva 2009 for the Prolog and Yusov 2009 for the service, both with detailed previous bibliography and discussion. 


\subsection{The Theoretical Impossibility of the "Russian" Approach}

The main reason for the development of a "Russian" view in the first place is the complete silence of the Byzantine sources. Indeed, this silence is considered as sufficient cause to declare fictitious the whole Russian tradition of a Constantinopolitan origin of the feast. ${ }^{12}$ The weakness of such reasoning is obvious because we know other examples of complete silence in the Byzantine sources on important events concerning both Byzantium and Russia, e.g., the Baptism of Rus' in 988. As far as I know, nobody declares this story fictitious because it is not mentioned in Byzantine sources. But let us look at the methodological basis of the "Russian" approach more closely. Rejection of some Russian sources is not its worst sin.

In fact, the "Russian" approach presupposes that the Russians, in order to address their own liturgical needs, which were quite different from those of Byzantium, searched through Byzantine books in order to find something they could use, but something that was not used already by the Greeks. In this way, they came across a story of a vision in the Life of a saint who was never especially venerated in Russia before, Andrew the Salos..$^{13}$ Alternatively, if one of the Slavonic versions of the Life of Andrew became available before the hypothetical date of the feast's establishment in Russia, the idea to use this particular text as the main source implies that the popularity of St Andrew had arisen explosively in Russia at this time, with no known cause. Following this hypothesis, the Russians would have created their feast and invented its false history of establishment under Leo the Wise in order to make this new liturgical custom more authoritative.

The probability of such a chain of events is similar to that of violating the second law of thermodynamics: although technically the probability is greater than zero, in practice, it will never happen.

(12) Cf., e.g., SpAsskij 1898, 283-284.

(13) A correlation between the cult of Andrew the Salos and the cult of Pokrov in Russia is proven, at least, for the North-West Russian lands (Novgorod principality); see the culturological and textological proofs in Yusov 2009, 58-65, and И. Е. Юсов, Службы Андрею Юродивому и Покрову Пресвятой Богородицы: историко-культурные и межтекстовые связи [I. E. Yusov, The Services to Andrew the Salos and the Pokrov of the Most Holy Theotokos: historic-cultural and intertextual connexions], Древняя Русь (2008) Nr 2 (32), 85-90. 
First of all, one would need to show at least one example of a similar history of some feast somewhere in the Christian world, even if not in Russia. That is, the establishment of a national feast commemorating an event which took place in a foreign land and is known solely from a foreign book, not from a living liturgical tradition. In fact, we know only examples attesting to the opposite procedure for establishing a feast. It was absolutely no problem, in Russia or anywhere else, to establish a new feast commemorating some remarkable events without any need of clothing it in Byzantine dress. Unlike some holy books, the holy feasts do not need pseudepigraphic attribution.

Even if the allegedly pseudepigraphic attribution to Leo the Wise is considered as a later addition to the genuine Russian tradition of the feast, the idea of searching for an appropriate miracle of the Theotokos in the Greek books is beyond the bounds of probability. Why not use any of the already-established feasts commemorating the miraculous intercession of the Theotokos if, for whatever reason, it had been decided that actual Russian realities must be commemorated by relying solely on Byzantine traditions? Why such an obsession to establish a feast that is not Byzantine yet, at the same time, is Byzantine in its content? All these questions must be answered not by relying on psychological reasoning but within the frame of the laws of liturgical development.

Let us therefore consider the methodological basis of the "Russian" approach in a more formal way.

This approach implies that the Russians created a new feast which:

(1) is not known to the former (Byzantine) liturgical tradition, but

(2) commemorates some event of the Byzantine past, with no apparent connexion to Rus', and

(3) without the appearance of any pertinent object (e.g. relics of Andrew) anywhere in Rus'.

It is apparent from the outset that such an institution, if it is possible at all, would be quite unusual. We find in general two approaches to establishing a new liturgical feast: either a modification of a previously existing liturgical tradition, in conformity with the first law of Baumstark (the Law of Organic Development), ${ }^{14}$ or the creation of a

(14) The Law of Organic (Progressive) Development presupposes that the new elements in the liturgy at first take their places alongside the more primitive elements but, in the course of time, cause the latter to be abbreviated and even to disappear completely; A. Baumstark, Comparative Liturgy. Tr. A. R. Mowbray (London-Westminster, MD, 1958) 23-24. Cf. R. TAFT, An- 
new cult at the place of the commemoration of the event itself, e.g., the relics (grave) of a saint. Such a place (which Delehaye calls the "hagiographical coordinate of place") for the event of Pokrov is the Blachernae Church in Constantinople but not its replicas, the Russian "Blachernae" churches ${ }^{15}$ - thus in accordance with Delehaye's principles of cult development. ${ }^{16}$ In the latter case, however, the new cult will be patterned after previously existing analogous cults and its future will be in conformity with the Law of Organic Development of Baumstark.

In the case of Pokrov, the "Russian" approach provides neither a previous liturgical tradition nor a genuine place of commemoration proper to Rus'. On the contrary, the genuine place of commemoration is clearly a Constantinopolitan one.

There are, of course, alternative paths. There are some legends that were created not "on the graves of martyrs" but purely from an ideology; nevertheless, they resulted in the creation of some specific cults. Among the best known examples are the fourth-century Constantinopolitan legends about St Irene and St Sophia, both of which resulted, first, in the two main cathedrals of the post-Constantinian capital, Hagia Sophia and Hagia Irene. ${ }^{17} \mathrm{~A}$ bit later, modification of the Sophia legend (Sophia and her daughters Pistis, Elpis, and Agape; no later than

ton Baumstark's Comparative Liturgy Revisited, in IDEM and G. WINKLER (eds.), Acts of the International Congress: Comparative Liturgy Fifty Years after Anton Baumstark (1872-1948), Rome, 25-29 September 1998 (Rome, 2001) (OCA, 265) 191-232.

(15) Evgenij Golubinskij believed that the feast could have been established by some private person in one of the Russian "Blachernae" churches: Е. Голуьинский, История Русской изеркви [The History of the Russian Church]. T. I, вторая половина тома (Moscow, $\left.{ }^{2} 1904\right) 403$ [there is a reprint (Moscow, 1997) with different pagination]. This would be probable only if this new Russian Blachernae cult was commemorating something from the already existing Constantinopolitan Blachernae liturgical customs. Golubinskij was criticised already by SPASSKIJ 1898, 241-242, but did not take into account his criticisms in the second edition of his book.

(16) See especially H. Delehaye, Les passions des martyrs et les genres littéraires (Bruxelles, ${ }^{21966)}$ (SH, $13 \mathrm{~B}$ ); IDEM, Les origines du culte des martyrs (Bruxelles, $\left.{ }^{2} 1933\right)(\mathrm{SH}, 20)$; on the concept of "hagiographical coordinates" see IDEM, Cinq leçons sur la méthode hagiographique (Bruxelles, 1934) (SH, 21).

(17) Cf. M. van Esbroeck, Le saint comme symbole, in: S. Hackel (ed.), The Byzantine Saint. University of Birmingham XIV Spring Symposium of Byzantine Studies (London, 1981) (Studies Supplementary to Sobornost, 5) 128-140. 
the early fifth century) resulted in two different cults in Rome, with two different martyria and two different sets of relics, the martyrs Sapientia and her daughters Fides, Spes, and Charitas in St Pancratius Church on the Via Aureliana (30 September for Sapientia, 1 August for her daughters) and the martyrs Sophia and her daughters Pistis, Elpis, and Agape (17 September) in St Cecilia Church at the St Callixtus graveyard on the Via Appia. ${ }^{18}$ One can see that the holy relics appear in due quantity even in the case when the cult is duplicated as a result of two different ways of borrowing and difficulties in translation.

What certainly cannot be seen is the appearance of a cult with no relics or any other marker of the hagiographical coordinate of place. Delehaye's main point is that any cult, in order to be established, must have a proper coordinate of place. Normally, it is the place that appears first, but the inverse order is also possible. What is impossible, however, is the creation of a new cult with no proper coordinate of place at all.

Let us return to our case of the feast of Pokrov. It has no coordinate of place other than that of Constantinople - there are no Russian coordinates of place at all. We must therefore exclude Rus' as a possible place of its creation. To prove the contrary, one needs to demonstrate that there was an earliest form of the Pokrov cult where the commemorated miracle is attributed to some Russian locality. Unless this can be demonstrated, there is only one theoretical possibility, namely, that the feast goes back to the Blachernae Church in Constantinople.

Of course, this possibility faces a major difficulty, for it must account for why this feast disappeared in Constantinople but was preserved in Russia. John Wortley proposed a way to deal with this difficulty already in 1971.

\subsection{Wortley's Hypothesis}

In 1971, John Wortley published a hypothesis explaining both the rapid disappearance of the feast of Pokrov in Byzantium and its establishment in Russia. ${ }^{19}$ Wortley was aware of the existence of Russian sources dating the establishment of the feast to the rule of Leo the Wise (886-912), and considered this dating as probable because of its corre-

(18) F. HALKIN, Légendes grecques de «Martyres romanes» (Bruxelles, 1973) (SH, 55) 179-180.

(19) Wortley 1971. 
spondence to the lifetime of the historical Andrew the Salos (although his Life places St Andrew under Leo the Great, 457-474).

Wortley proposed to date the establishment of the feast to the patriarchate of Euthymius (907-912) and, more exactly, to 911. In this case, it is likely that the feast was abrogated by the next patriarch, Nicholas Mystikos, during his second patriarchate (912-925), most likely at the very outset of his tenure, in 912 . This action would correspond to the general politics of Nicholas with respect to his predecessor Euthymius.

Euthymius became patriarch after the uncanonical deposition of Nicholas in 907 because of the strict position of the latter in the tetragamia affair. After the death of Leo the Wise, Nicholas returned to his throne and declared the whole activity of Euthymius unlawful. He even went so far as to depose clergy ordained by his predecessor. Unfortunately, in the Life of Euthymius the corresponding period is absent because of a lacuna in the only preserved manuscript. Nevertheless, the abrogation of a solemn feast, if it was established by Euthymius, is very likely under Nicholas.

The problem, however, is that such an ephemeral feast is unlikely to have been accepted by the Russians, given that Rus' of this epoch is now considered as a pagan state. Wortley finds an elegant answer by recalling that, in the same epoch, a Russian embassy spent a great deal of time in Constantinople negotiating the peace treaty after the war of the Kievan prince Oleg against Byzantium. The date of the signing of the peace treaty is known exactly: 2 September $911 .{ }^{20}$ The Russian chronicle (Primary Chronicle, so-called Povesst' vremennyx lèt) tells us that, before going back to Kiev, the embassy visited remarkable places and attended divine services in Constantinople. The Greeks were trying to impress the Russians by displaying the beauties of their civilisation. Thus, Wortley concludes, it is unlikely that the embassy departed before 1 October. If the feast of Pokrov was already established, its service must have been seen by the visiting Russians, who might then have translated the custom of this feast to Kiev.

(20) This does not take into account the complex problems of the exact dating of Oleg's campaign against Byzantium and the historicity of the previous Russian-Byzantine treaty of 907. These problems are not mentioned by Wortley but they do not affect his argument because, at least, the date of the 911 treaty is not disputed. On the chronological difficulties, see especially А. Г. Кузьмин, Начальные әтапь древнерусского летописания [А. G. Kuz'міл, The Initial Stages of the Old Russian Chronography] (Moscow, 1977) 263-265. 
Wortley's hypothesis was never refuted but it is largely ignored by scholars writing on the origins of Pokrov. ${ }^{21}$ Unfortunately, just as Wortley did not discuss the Russian bibliography of the topic, so his Slavic colleagues do not mention his article very often and, even in the rare cases when they do mention it, they do not consider it in any depth. Wortley's arguments, however, might easily be supported by evidence from Russian sources.

(21) There has been no discussion of his paper, as Professor Wortley confirmed to me in his e-mail message of 26 August 2010. The only exception is the article by L. Rydén, The Vision of the Virgin at Blachernae and the Feast of the Pokrov, AB 94 (1976) 63-82, here 63, 78-81. Rydén's arguments are as follows: 1. "At that time [911] Russians still had to learn [the] very basics of Christianity. It is not likely that they at this stage were capable of understanding such subtleties as the role played by the Mother of God in the religious life of the inhabitants of Constantinople... If the Kievans adopted the Mother of God as their particular protectress, this would mean that they regarded their city as a new Constantinople." But this was not the case yet; the only known Kievan church of the middle of the $10^{\text {th }}$ century was dedicated to St Elias, not to the Virgin (p. 79-80). - These considerations, however, do not prevent us from supposing that the Theotokos was considered as another heavenly protector of the Kievan Christians, together with Elias; the available data on the earliest years of Kievan Christianity are far from being representative, and are thus insufficient to exclude such a supposition. 2. "If, as Wortley suggests, the passage under consideration in the Life of Andreas Salos reflects a feast celebrated at Blachernae on 1 October 911, it follows that Nicephorus [author of the Life] committed a rather serious anachronism" when he stated elsewhere that Andreas lived in the fifth century (p. 80). - In fact, Wortley said that 911 is the date of the establishment of the feast, not of the vision itself (cf. below, 1.8 , where it is shown that the vision took place earlier than the feast was established). 3. "...if we suppose that the alleged festival on 1 October 911 was arranged to celebrate the vision described in the Life of Andreas Salos, we must also suppose that the Vita was written before that date," which is extremely unlikely (p. 80). - This argument reveals a tacit assumption that the Life was written as a single document all at once, which is in fact impossible (s. below, 1.8.2). I will demonstrate below that the legend of the vision must predate the available recension of the Life. 4. It is unlikely "...that the patriarch of Constantinople inaugurated a new festival on the basis of a passage in the Life of Andreas Salos just a few years after this Vita had been written" (p. 80-81). - This may be true, but the argument implies the same incorrect assumption. Thus, Rydén's argumentation against Wortley is unconvincing. 


\subsection{The Christian Community in Kiev in the Time of Patriarch Euthymius}

In the early tenth century, there was a Christian community in Kiev and, moreover, some Christian participation in the Oleg embassy is very likely. The total number of Russians living in Constantinople, where they lived in their allotted quarter of St Mamas, was at this time several hundred. Most of them were merchants and soldiers in the service of the Byzantine emperor. ${ }^{22}$

Although, judging from their names, none of Oleg's ambassadors in the 911 mission appears to have been Christian, the embassy included additional personnel, so the presence of Christians in the party as a whole seems likely. The next time the Russians signed a treaty with Byzantium, in 944, about half of the Russian ambassadors were Christians. They gave their oaths in the church while another group of Russian ambassadors did the same before their idols. Under this date, 944, the Russian Primary Chronicle mentions the Church of Prophet Elias in Kiev. The existence of this church at this date is reported as a known fact, which implies that the church existed for a relatively long time before this. ${ }^{23}$

The establishment of the Christian community in Kiev goes back to the repercussions of the Russian attack on Constantinople in 860, that is, to the so-called first Baptism of Rus' under Patriarch Photius (the only Baptism of Rus' known to Byzantine sources; s. Photius, Encyclical Epistle [867]) and/or under Emperor Basil I and Patriarch Ignatius in about 974 (s. Theophanes Continuatus, Basilius, 97). ${ }^{24}$

(22) See, for details and an estimate of the Russian population, Г. Г. АиТАврин, Условия пребывания древних русов в Константинополе в Х в. и их юридический статус [G. G. Litavrin, The Conditions of the Sojourn of the Old Rus'ians in Constantinople in the Tenth Century and Their Legal Status], ВВ 54 (1993) 81-92 [reprinted in IDEм, Византия, Болгария, Древняя Русь (IX - - maчaлo XII в.) [Byzantium, Bulgaria, and Old Rus' (ninth-early twelfth centuries)] (St Petersburg, 2000) (Византийская библиотека)].

(23) On the possibility of the existence of a St Elias church in Kiev long before 944, see C. А. Иванов, Когда в Киеве появился первый христианский храм? [S. A. Ivanov, When did the First Christian Church Appear in Kiev?], Славяне и их соседи, вып. 11 (Moscow, 2004) 9-18. There is also a hypercritical point of view according to which the entry in the Primary Chronicle corresponding to 944 transposes the realities of the twelfth century.

(24) For the whole dossier, see П. В. Кузенков, Поход 860 г. на Константинополь и первое крещение Руси в средневековых письменных источ- 
Thus, there was a good channel by means of which to translate to Kiev the new liturgical custom if it had been established under Patriarch Euthymius. There is no need to speculate how this might have been possible via the pagans. The Russian milieu of Constantinople and, very probably, Oleg's embassy of 911 contained a significant Christian minority.

A specific feast inherited from the epoch of the earliest period of Russian Christianity must have been highly esteemed after the Baptism of Rus' under Prince Vladimir in 988 and it would have become an important part of the common Kievan heritage of all subsequent developments of the Russian Christian tradition.

One can ask why this feast was not abrogated in Rus' at the time it was abrogated in Constantinople, given that the Kievan Christian community was under the omophorion of the Constantinopolitan patriarch. The answer is that only Nicholas Mystikos personally could have been interested in such an action. In his lifetime, however, the relations with the Kievan Christian community were weak and intermittent.

\subsection{A South Slavic Alternative}

It is known that the Slavonic liturgical and hagiographical texts became available in Kievan Rus' mostly from South Slavs, especially from Bulgaria. The earliest mention of the feast of Pokrov in a South Slavic document goes back to the second quarter of the thirteenth century. ${ }^{25}$ No wonder that it was usually explained as resulting from Russian influence. But if we are not limited to the "Russian" hypothesis of the origin of the feast, this explanation ceases to be obvious.

In fact, South Slavic manuscripts earlier than the thirteenth century are very rare. Most of the early South Slavic texts are available through the Russian manuscript tradition. Thus, the number of early South Slavic manuscripts available to us is far from being representative.

It is still an open possibility that the Pokrov feast was borrowed by Kievan Rus' from Bulgaria together with the whole set of liturgi-

никах [P. V. Kuzenkov, The Campaign of 860 against Constantinople and the First Baptism of Rus' in the Mediaeval Literary Sources], in: Аревнейшие государства Восточной Европь. 2000 г.: Проблемь источниковедения (Mоscow, 2003) 3-172. The question of how these two ninth-century Baptisms of Rus' are related to one another is still a hotly debated topic.

(25) See above, note 9. 
cal books, somewhere in the late tenth century or even earlier, at the time when there was only one Christian church in pagan Kiev. This hypothesis is corroborated by the history of the First Bulgarian Kingdom (ca 681-1018), especially under Symeon I (893-927). ${ }^{26}$

Symeon had kept peace with Leo the Wise from 904, but almost immediately after Leo's death, in 913, he started the war that lasted until his own death in 927. Before the war, it was normal that Bulgaria, as part of the patriarchate, accepted Constantinople's liturgical innovations. During the war, however, it was not very probable. Therefore, if the feast of Pokrov was established before 913, it is likely that it was accepted by the Bulgarian metropolis. If this feast was abrogated in Byzantium during the war (or even in 912, one year earlier), it is unlikely that it was abrogated in Bulgaria before 1018, when, after the end of the First Bulgarian Kingdom, the real dependency of the metropolis of Bulgaria on Constantinople became much stronger.

This "South Slavic alternative" could seem more probable than a direct impact of Constantinople on Kiev because it corresponds to the most usual routes by which Greek Church culture penetrated Kievan Rus' and does not contradict any established fact. Moreover, it is corroborated by the fact of one relatively early mention of Pokrov in a South Slavic document.

Be that as it may, both alternative hypotheses demonstrate that there were enough means to translate the feast of Pokrov to Kiev if this feast had been established in the period from 907 to 911, and to prevent its abrogation in Kiev after its abrogation in Byzantium in about 912.

\subsection{The Original Meaning of the Feast of Pokrov According to Pachomius Logothetos}

Pachomius Logothetos, in his sermon on Pokrov ${ }^{27}$ written in Novgorod for the Novgorodian Archbishop Iona (Jonas) in the 1460s, gives important information unknown from other sources. ${ }^{28}$ He was

(26) See, as a general introduction: Д. Косев и др. (ред.), История на България в четиринадесет тома. Т. 2: Първа българска дьржава [D. Kosev et al. (eds.), The History of Bulgaria in fourteen volumes. Vol. 2: The First Bulgarian Kingdom] (Sofia, 1981). Cf. S. Runciman, A History of the First Bulgarian Empire (London, 1930).

(27) BMY, cols. 17-23.

(28) His sermon is considered as a compilation based on the Prolog sermon on Pokrov and the service of the feast; s. Е. А. ФЕт, Слова на Покров 
asked to compose a work of high rhetoric based on information provided to him by Russian Church officials. The plot of the story is the same as in the other sources but with one remarkable exception. This is an additional detail explaining the nature of the difficult situation that existed when the Theotokos gave her vision to St Andrew, due to troubles in the Church. The exact wording of Pachomius ${ }^{29}$ is rather revealing:

Но понеже убо добро есть навыкнути, откуду и коея ради вины сей пречестный Покрова праздник уставиша святеи отцы в Костянтинеграде праздновати, елма убо в Костянтинеграде, в немже спасеная содевахуся, но понеже тамо, истинне умаляемей, грех множашеся, яко и при Пророце: виде бо и Давид в Израиле истинну умаляему, помодися гдагодя: спаси мя, Господи, яко оскуде преподобныи, и яко умалишася истины от сынов чеиовеческых; егда бо правда одолевает беззаконию, тогда бо мииосердие Божие к себе привлачим, а егда ли грех, тогда негодование Божие. Якоже прежде рехом, в Костянтине граде некая стропотная съдевахуся, могуща негодование Божие навести; но нигде же не оставляет Богородица помощию, но непрестанно модится и модитися не престает о чедовечьском роде.
But it is good to know from where and out of which occasion the holy fathers established in Constantinople to celebrate this most solemn feast of Pokrov. It was still in Constantinople, where [other] salvatory events took place, but because here, when the truth was diminishing the sin was multiplying, as it was under the Prophet. Indeed, when David saw the truth diminishing in Israel he prayed, saying: Salvum me fac Domine quoniam defecit sanctus quoniam deminutae sunt veritates a filiis hominum (Ps 11:2 [12:1]). Because [it is known that] when truth overcomes unlawfulness we attract to ourselves God's mercy, but when sin [predominates, we attract to ourselves] God's indignation. As we have said above, in the Constantine city there took place some evildoings which were able to provoke God's indignation. However, nowhere does the Theotokos leave without help but continuously prays and [she] does not cease to pray of the human race.

[Е. A. Fet, Sermons on Pokrov], in: Д. С. Аихачев (ред.), Словарь книжников и книжности Древней Руси. Вып. I (XI - первая половина XIV в.) (Leningrad, 1987), electronic publication at http://www.pushkinskijdom.ru/Default. aspx?tabid $=4629$. This evaluation is inexact.

(29) BMY, cols. 18-19, quoted with simplified orthography. 
The passage quoted above has no parallel in other widely known sources (although in the next section we will note a parallel in an unpublished source that has never been studied properly).

We know that, normally, the situations of miraculous intercession of the Theotokos were connected with a war or a siege, both in Byzantium and in Rus'. Here, however, the situation was certainly different. If the story had been deliberately invented, it seems extremely likely that a war or siege would have been mentioned as a direct cause of the intercession. Thus, Pachomius' account, with its specific reference to unrest and public danger, appears to be genuine, to reflect the actual events of the time. In the time of Euthymius' patriarchate, only one such instance of Church troubles is likely: it was the time of the tetragamia affair. The fourth marriage of the emperor was considered as a sinful action with a high potential of public danger, and its recognition by the Church appeared as still more dangerous.

Pachomius Logothetos does not mention Leo the Wise nor does he give any other reference that might establish an absolute dating, but his account perfectly fits the historical context presupposed by Wortley's hypothesis. Indeed, there were severe Church troubles at the beginning of Euthymius' patriarchate in 907 that did not cease before the Council of Union in 920, under Nicholas Mystikos (and, indeed, these troubles continued to the late tenth century). The compromise between the two competing Church factions achieved in the Tomos of Union of 920 eventually stabilised but, before this, the situation remained especially troublesome. The vision of St Andrew celebrated in the feast of Pokrov would have ideally suited Patriarch Euthymius as a sign of the intercession of the Theotokos fulfilling the lack of legitimacy. But this was certainly not the decision Nicholas Mystikos was able to accept in 912.

Of course, another explanation of Pachomius' passage is theoretically possible. Namely, that he already had in mind the attribution to Leo the Wise and was trying to harmonise his account with this. Leo the Wise is mentioned in the preserved Pokrov texts not earlier than the eighteenth century ${ }^{30}$ and his name is not traceable in the ear-

(30) “Покров уставися праздновати во дни царя Льва Премудраго в лето 6611 (Pokrov was established to be celebrated in the days of the Emperor Leo the Wise in the year 6611)"; Г. Д. Филимонов, Иконописный подлинник сводной редакичии XVIII века [G. D. Filimonov, A Manual of Iconography of the Cumulative Recension of the Eighteenth Century] (Moscow, 1876) 163. As to the odd date AM 6611 (AD 1103), cf. considerations by ПлюхановА, Сюжеты $и$ 
lier sources. However, our set of sources may be not representative enough, so there is thus nothing preventing this attribution from going back to the time of Pachomius Logothetos and even to the earliest Kievan Christian community. It is doubtful, nevertheless, that Pachomius would not mention Leo the Wise if he were aware of his role. Such a reference would add some authority to the feast, without being in any way compromising. Thus, the most natural explanation is that in the fifteenth-century Novgorodian Pokrov tradition that became available to Pachomius Logothetos via Archbishop Iona, the name of Leo the Wise has been dropped but some memory of the tetragamia affair was still preserved.

\subsection{BHG 1136d: a Greek Homily on Pokrov}

In the list of the homilies on Pokrov which are considered as being Russian, there are three unpublished ones (all anonymous). ${ }^{31}$ One of them is known in several manuscripts, sometimes under 15 August, as a sermon on the Dormition of the Theotokos. The earliest Russian manuscript (fifteenth century), ${ }^{32}$ however, places it as a homily on

символью..., 32: in 1103, there was nothing interesting occurring in Constantinople but, according to the Primary Chronicle, this is the year of the first Russian victory of a purely miraculous nature (Prince Vladimir Monomachos was praying for a victory over the Polovtsians and, in fear, their army took flight without a battle). Pliukhanova hints that this date could be a trace of some (re)shaping of the feast under Vladimir Monomachos (Kievan prince from 1113 to 1125, in 1103 prince of Perejaslavl).

(31) In addition to the two (not three) listed as unpublished by ФЕт, Слова на Покров (the last item in her list is, in fact, a very well known text published many times within the Menologion of Dimitry of Rostov, from the eighteenth century and of no interest to our purpose) a third text appears in Moldovan 2000, 117 (inc. Древле Израиля сущаго...). From these three homilies, I was able to check only one (to be discussed in this section), but the two others need to be studied in the future. They may contain some material of Byzantine origin. One of them is a panegyric on Pokrov with the incipit "Светлое и преславное настоящее торжество..." which is characterised by Fet as a compilative work of the sixteenth century (based, apparently, on the date of the earliest manuscript) composed from several other sermons on the Pokrov and other feasts of the Theotokos. At least, its beginning is borrowed in the homily of George of Nicomedia (ninth century) on the Conception of the Theotokos by Anna, BHG 1111 (PG 100, 1336-1354).

(32) Russian State Library (Moscow), Bolshakov coll., Nr 66, ff. 204v$214 \mathrm{v}$. According to ФЕт, Слова на Покров, the sermon is of rare occurrence. 
Pokrov. I was able to check another manuscript (dated to 1627 in the colophon), where it is placed under 15 August as a homily on the Dormition. ${ }^{33}$ Indeed, the title aside ("Sermon on the Dormition..."), there is absolutely no Dormition motive in the whole of this text. The main motive is the penitence of the faithful and the intercession of the Theotokos, but the Pokrov of Theotokos is present in a long prayer which concludes the homily. Such prayers are a usual feature of the Pokrov homiletics, as Spasskij observed, ${ }^{34}$ but not of the homiletics associated with the Dormition. The prayer in our homily reveals its liturgical setting, so it would be more fruitful to discuss it a bit later.

\subsubsection{The Greek Original and Its Pseudepigraphic Authorship}

It is important to state now that, on the basis of incipit, ${ }^{35}$ desinit, $^{36}$ and attribution to the Dormition, our Slavonic homily coincides with the unpublished homily on the Dormition BHG 1136d attributed to Patriarch of Constantinople German II (1222-1240). I think these coincidences are enough to identify the two homilies. ${ }^{37}$ Unfortunately, I was unable to check any of the Greek manuscripts. Thus, my following consideration must be rechecked and, most probably, corrected

(33) Russian State Library (Moscow), Collection of the Holy Trinity and St Sergius Laura, Nr 681 (olim 410), ff. 423-430v. Quoted with simplified orthography.

(34) Spasskij 1898, 263-265, on the prayers in the Prolog sermon, that of Pachomius Logothetos, and an anonymous sermon (according to Фет, Слова на Покров, based on Pachomius) published in BMЧ.

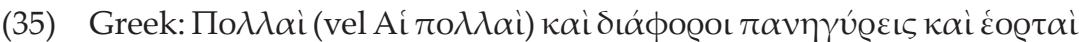

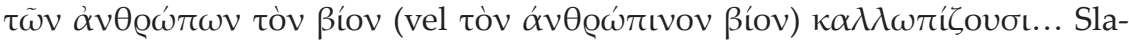
vonic: Многораздична торжества и праздницы человеческое житие украшают... Translation: "Many and different solemnities and feasts decorate the human life..."

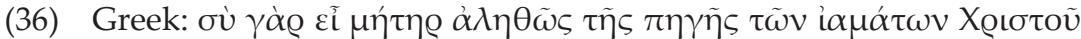

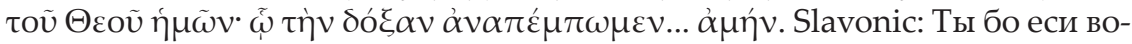
истинну источника целбам Христа Бога нашего, Емуже славу воздаем.... Аминь. Translation: "...because Thou art in truth the mother of the source of healings, Christ our God, to Whom we address the glory... amen." In my Slavonic manuscript the word "mother" is omitted by the scribe but then added in the margin. Halkin, in the Novum Auctarium of BHG, indexes one manuscript with a completely different desinit.

(37) And to abandon Fet's conclusion that the sermon was "composed in the fifteenth century by a monk of an unknown monastery [sc., Russian]" (ФET, Слова на Покров). 
when both Greek and Slavonic texts are published. At any rate, after the identification of the Greek original of one of the allegedly Russian sermons on Pokrov, the main argument of the partisans of its Russian origin becomes shakier.

The authorship of German is attested in the most of Greek manuscripts $^{38}$ and was thus accepted by Albert Ehrhard and by the scholarly consensus summarised by Hans-Georg Beck as a mark of German II's authorship. ${ }^{39}$ However, the attribution to an unspecified Patriarch German is not a rare occurrence in the Byzantine homiletics. If some work ascribed to "Patriarch German" is too late for attribution to German I (715-730), this does not mean that it is to be automatically attributed to German II. Finally, one of the more recently discovered manuscripts, codex Meteor. 516, contains our homily with attribution to John Chrysostom. ${ }^{40}$

There is another reason to doubt German's authorship. Our homily, in its prayer section, mentions "Emperors" in the plural (Slavonic: царей наших сохрани, "our Emperors savest," f. 429 $\mathrm{v}^{41}$ ). This corresponds to a situation when there were two or more emperors. Such a situation was permanent throughout the reign of Leo the Wise but not in the time of German II. The latter was patriarch under only one Emperor of Nicaea, John III Vatatzes (1221-1254).

Thus, the most reasonable conclusion seems to me that the real authorship of the homily was suppressed (and this stage is preserved in its Slavonic tradition, where the homily is always anonymous) but then the homily was reattributed to the common authorities of the late Byzantine pseudepigraphic homiletics, "German" and Chrysostom.

(38) Ehrhard knew three manuscripts to which one more has been added by Halkin in BHG and five more were added by Ehrhard himself in the Novum Auctarium of BHG. Thus, nine manuscripts are now known to BHG.

(39) H.-G. Веск, Kirche und theologische Literatur im Byzantinischen Reich (Munich, 1959) (BH, II, 1) 668.

(40) Described by N. A. Bees in 1967 and referred to by Halkin in the Novum Auctarium.

(41) Corrected into singular царя нашего on margin. The phrase continues with singular in the next line (емy "to him," sc., to the Emperor). 


\subsubsection{Liturgical Setting and Contents: Pokrov Vigil}

The process of deleting and the subsequent falsification of the authorship of this homily was paralleled by a rethinking of its contents. It is clear that the sermon has nothing to do with the Dormition. It is rightly defined by Fet as "a sermon of moralistic contents." ${ }^{42}$ Our assurance that it was actually delivered on some festive occasion follows from the opening phrases only (cf. incipit). The preacher starts by mentioning the two different manners of celebrating - good and the bad - and from there proceeds to a long moral admonition with appeals to penitence, concluding his speech with a long prayer to the Theotokos. This prayer is a kind of compensation for the complete lack of any other information on the feast being celebrated by the congregation. From this, it is at least clear that the feast is connected to the Theotokos.

But which feast might be indicated? One might suggest that all the major feasts of the Theotokos are to be excluded on the same grounds as the Dormition: there is nothing specific, in our sermon, which can be understood as marks of the Nativity of the Theotokos, or the Presentation, Hypopante, or Annunciation. Normally, the homilies delivered on these feasts contain many specific festal motives. Celebrations of miraculous intercessions of the Theotokos in the cases of wars and sieges (such as the Saturday of Akathistos, but there were many others as well) are to be excluded on similar grounds. Finally, one has to exclude any celebration of some Theotokian relics (such as the Robe or the Girdle or an especially venerated icon) because none of them is mentioned. What, then, remains? Let us see the text itself.

The long prayer at the end of the homily contains the following (I will quote starting from the opening passages and continuing to a passage near the end):

(f. 429r) Владыко вседержителю, умолен буди рукама понесших $(\mathrm{sic})^{43}$ Тебе простираемых (sic) к Тебе нас ради.
Almighty Master ( $\triangle \dot{\varepsilon} \sigma \pi \mathrm{\sigma} \alpha \tau \alpha \alpha v-$

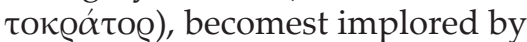
the hands that were bearing Thee, that are spread to Thee for us.

(42) “[С]лово нравоучительного содержания" (ФЕт, Слова на Покров).

(43) Here and in the next case marked by "sic" the participle is not in grammatical agreement with the instrumental case of the dual рукама "by (two) hands." The correct forms are nонесшима and простираемыми. The late Church Slavonic scribes were uneasy with dual forms. 
О Владычице милостивая, источниче благо-(f. 429v)сердия, источниче милости, простри к Сыну Своему пречистыя Си длани. Сохрани нас заступлением Своим, покрыи нас покровом крил Твоих, пре $<д>$ стани о всех ради християн ходатаица.

(f. 430v) ...яко Тебе имам<ы> помощницу и предстателницу непобедиму и крепку заступницу и покров и прибежище душам и телесем нашым...
Oh Lady merciful, the source of misericordy, the source of mercy, spreadest to Thy Son the most pure Thy palms. Preservest us by Thy intercession, coverest us by the cover (Pokrov) of Thy wings

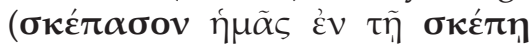

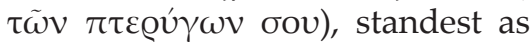
the intercessor of all the Christians. ...because we have Thee as a helper and a protector invincible and a strong defender and a cover ( $\sigma \kappa \varepsilon \dot{-}$ $\pi \eta$ ) and a refuge of our souls and bodies...

These quotes are enough to justify the Russian scribes who used this sermon as a sermon on Pokrov, but they are not enough per se to prove a stronger claim that the sermon was originally delivered on Pokrov. Such a claim may be proved or disproved with an analysis of the liturgical setting.

The Greek inclusions within my English translation correspond to the phrases known from other prayers. Our prayer as a whole is a reworking of the well-known prayer $\Delta \varepsilon \dot{\sigma} \sigma \pi \mathrm{\tau} \alpha \pi \mathrm{o} \lambda \nu \varepsilon \dot{\lambda} \lambda \varepsilon$ ("All-Merciful Master") but, in this case, readdressed to the Theotokos. As it seems,

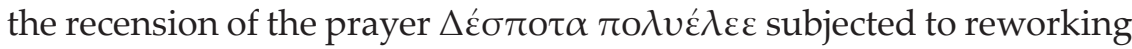

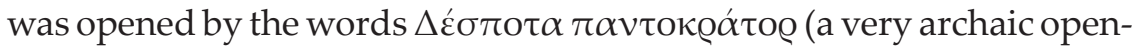
ing phrase preserved relatively rarely in the prayers actually used ${ }^{44}$ but is known, at least, from the Eucharistic prayer in Didache, 10). Nevertheless, the whole structure of the prayer in our homily suggests that it

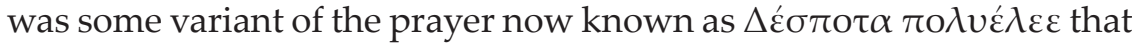
the preacher had in mind. The most important phrase of the whole of

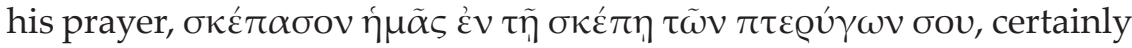
goes back to this source, where it is presented in this form rather than citing its Psalter prototype directly. ${ }^{45}$

But the prayer $\Delta \varepsilon \dot{\varepsilon} \sigma \pi 0 \tau \alpha \pi \mathrm{O} \lambda v \varepsilon \dot{\lambda} \varepsilon \varepsilon$ presupposes a specific liturgical setting. In present-day use, it is preserved at the end of Compline Gifts.

(44) Cf., e.g., the Opisthambon prayer of the Liturgy of the Presanctified

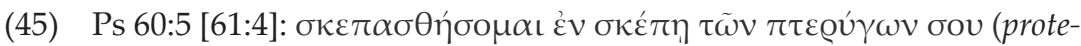
gar in velamento alarum tuarum) "I will shelter myself under the shadow of thy wings" (Brenton). 
(where it is read when the congregation is genuflected and bent down) and in the rite of Artoklasia (the Church Slavonic term is лития, from Greek $\lambda ı \imath \eta$, a kind of prayer) which can be introduced at the end of Great Vespers (where it is read as a prayer at the bowing of the heads). In both cases it is preceded by a synapte. In both cases, this is a prayer of zealous supplication whose specific expression is signified by the postures of the faithful. The case of the Artoklasia is especially interesting to us for, regardless of the blessing of the bread, it is an additional supplication on the occasion of some solemn service. The main point of the latter is the prayer $\Delta \dot{\varepsilon} \sigma \pi 0 \tau \alpha \pi \mathrm{o} \lambda v \varepsilon \dot{\lambda \varepsilon \varepsilon}$ (and not the prayer of blessing of the bread which the celebrant reads after this).

Let us return to our homily. Its final prayer to the Theotokos, pat-

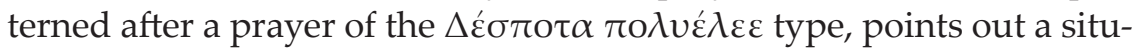
ation similar to that of the rite of Artoklasia. The congregation is immersed in zealous supplication to the Theotokos, most probably after Vespers and, thus, in full play of the festal all-night vigil (Pannychis). The supplication of the Artoklasia became united with the rite of the blessing of the bread especially for this purpose: to give to the faithful food for the remaining part of the all-night service.

Thus, it is natural that the purpose of the preacher is not to explain the meaning of the feast but, first of all, to urge the congregation to pray with more zeal. The homily unites an initial exhortation with the following prayer itself. The theme of penitence is the major theme throughout the prayer, and this is in conformation with the bowing of the heads accompanying this type of prayer on festal days (on the ferial days when Compline is served such a prayer is read when the faithful are genuflected and even bent down).

It is especially revealing that the end of Vespers is not a common place to deliver a homily. Our homily is not an ordinary one; it is rather a preface to an unusual prayer together with this prayer itself.

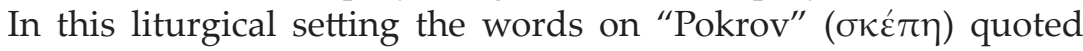
above must be taken much more seriously. Our exhortation with a prayer to the Theotokos ideally fits within the frame of the account of the vision of Andrew the Salos, when the whole congregation was gathered for the all-night vigil in the Blachernae Church. In the feast that was introduced for commemorating this event, such a specific prayer to the Theotokos is quite logically placed and the appearance of such an unusual homily is reasonable.

Otherwise, it is difficult to explain the origin of this homily-prayer addressing the Theotokos on the occasion of an unspecified feast, with no information on the meaning of this unnamed feast but rather with 
only a general appeal to penitence. Therefore, my conclusion is that BHG $1136 \mathrm{~d}$ is originally a sermon on Pokrov delivered between Vespers and the remaining part of the all-night vigil. Its difficult destiny in the Byzantine manuscript tradition was a direct consequence of the dropping of the feast of Pokrov from the Byzantine liturgy.

\subsubsection{Author: Patriarch Euthymius}

The homily is delivered by the head of the congregation, thus, in the frame of Wortley's hypothesis, the only candidate for authorship is Patriarch Euthymius. His name was partially affected by some kind of damnatio memoriae under the second patriarchate of Nicholas Mystikos, which is in perfect accord with the anonymity (or pseudonymity) of the sermon in the preserved part of the manuscript tradition.

One can highlight an interesting moment from the text of the homily that sheds some light on the circumstances of its delivery. An important part of the exhortation is a warning for the laics against the sin of blaming the monastics and the clergy (f. 427r-427v). The wording of the argumentation suggests that the bishops are meant, too:

(f. 427v) ...но аще согрешит кто от них, от Бога истязан будет и обличен, и в нынешнем веце и в будущем, и болшим архиереом, по правилах божественных, священноистязан будет. ...but if some of them [sc., monastics and clergy] commits a sin, he will be examined and revealed by God, both in this age and in a future age, and by a higher bishop, according to the divine canons, will be sacredly examined.

The expression "higher bishop" would be fitting if some court procedure concerning a bishop was meant. Unless there is some corruption in the text or in the translation, ${ }^{46}$ the above passage could be understood in connexion with some Church troubles that involved bishops. In the time of Leo the Wise, this was the tetragamia affair.

At any rate, our homily implies some public troubles, most likely connected to the Church, and this is in conformity with Pachomius Logothetos' version of the establishment of the feast of Pokrov.

(46) The phrase is somewhat problematic because Church legislation does not allow one bishop to judge another (a bishop can be judged only by a group of bishops). If the author means a court procedure over the monastics and the clergy, the word "higher" is meaningless because the bishop is always "higher" with respect to them. Thus, some corruption in the text is probable. 


\subsection{The Prolog Sermon on Pokrov}

The short sermon on Pokrov, ${ }^{47}$ known since the earliest manuscripts of the Russian Prolog, is considered as the most ancient homiletical monument of the feast. Indeed, its author says that he is now establishing this new feast for the first time. The sermon is thus extremely important for the historical study of Pokrov.

\subsubsection{Contents}

Below is the complete translation of the text, which I have divided into five parts:

(1) Title: "On the vision of St Andrew and Epiphanius." The first phrase of the following text is nothing but an enlarged title: "A strange and miraculous vision of the venerated saints Andrew and Epiphanius, how they saw the Holy Theotokos on the air and having come to the Blachernae Church, with the angels and with the Prodromos and with the Theologian John and with other many saints." ${ }^{\prime 4}$

(2) The scene of the vision, a very short account: "When the people were staying in the church, they [Andrew and Epiphanius] saw [Her] praying with tears of the whole world. And Andrew said to Epiphanius: Do you see the Queen and the Lady of all praying of the world? And he said: I see, father, and [I see Her] covering by Her holy omophorion shining more than the electron

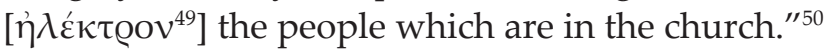

(47) Will be quoted (in simplified orthography, without taking into account grammatically incorrect readings) according to the critical edition: LoSEVA 2009, 312-314.

(48) Страшное и чюдное видение честною святителю [vel святьцю] Андрея и Епифания, како видеста святую Богородицю на воздусе, пришьдшю в Влахернскую церковь с ангелы и с Предтечею и с Богословьчем Иоаномь и с иными святыми мъногыми.

(49) Cf. Ezek 1:4, 1:27, 8:2, and a large mystical tradition of visions, both Jewish and Christian. "Electron" literally means here the alloy of gold and silver, not amber.

(50) Народу стоющу в церкви, видеста молящюся с сльзами за весь мир. И глагола Андреи к Епифану: Видиши ли Царицю и Госпожю всех молящюся за мир? Он же рече: Вижю, отче, и покрывъши святым Своим амофоромь, светящимся паче еликтора люди сущая в церкви. 
(3) The preacher speaks in the first person, stating why and how he established the feast: "When I heard this, I was thinking how this fearful and merciful vision and, moreover, our esperance and intercession remained without feast, but I was relying on Thy, Lady, merciful words which Thou hast said to Thy Son: 'Oh King of Heaven, acceptest every man glorifying Thee and calling Thy name, and sanctifiest every place where one commemorateth My name, and glorifiest those who glorify Thee, accepting for My name their every prayer and oath.' Relying on these words I wished that not without feast will remain Thy holy Pokrov, oh Blessed one! But in the manner that Thou wishest to decorate it, oh All-Merciful, decoratest the venerated feast of Thy Pokrov, in order that those who glorify Thee will be enjoyed seeing the most distinguished Thy feast shining forth." ${ }^{1}$

(4) Continuation of the prayer of the preacher: "In the same manner as Thou hast covered mercifully the people therein, coverest us [who are] Thy sinful servants by the cover of Thy mercy [vel wings]. And with defeating the councils and thoughts of the cogitantes about us mala [Ps 34:4], saveth by the mercy of Thy Son and [also] by Thine, in the present age and in the future, all those who are coming to Thee with fear and faith relying on Thee, [who art] the fast intercession and help." 52

(51) Се убо егда слышав, помышлях, како страшное и милосердьное се видение, паче же надеяние и заступление наше бысть без праздника. Надея же ся, Владычице, на милосердьная Твоя словеса еже к Сыну Си рече: «Царю Небесныи, прими вьсякого человека, славящаго Тя и призывающаго имя Твое, и всяко место, идеже бывает память имени Моего, освяти место и прослави прославляющяя Тя, именем Моим приемля их всяку молитву и обет». Тем словесем надеяся въсхотех да не без праздника останет святый покров Твой, Блаженая! Но якоже Ты украсити хощеши честныи праздник покрова Твоего, Всемилостивая, украси, да и прославляющии Тя вьзвеселяться видяще многоименьныи Твои праздьник сияюща.

(52) Якоже тамо народы сущыя покры милостивьно, тако и нас грешных раб Твоих покрыи кровом милости Твоея [vel крилу Твоею]. И низдагающи съветы и думы помышляющих на ны злая, спаси по милости Сына Твоего и Твоеи, и в сь векъ и в будущии, и вся прикающая к Тебе с страхом и верою, надеющяяся на Тя, скорое заступление и помощь. 
(5) Concluding remark: "Such feast was established to be celebrated on the 1 day of the month October, on the commemoration of saint apostle Ananias." 53

Sergij Spasskij noted several features of this account ${ }^{54}$ but some of his observations need to be reconsidered, while others still hold.

"The feast is established by the cause of hearing of the Life of St Andrew (вследствие слушания жития святаго Андрея)" or the relevant fragment of this Life, wrote Spasskij. This claim is unjustified by the text. The preacher said that he heard about the vision itself but not that he was hearing the lecture of some written Life. His "when I heard this" (part 3) points out the scene of vision (part 2) but not any written text.

"...thus," Spasskij continues, "(the feast) was established a relatively long time after the death of this saint (Andrew) (...следовательно, установлен спустя доводьное время по кончине этого святаго)." This conclusion is unacceptable in its present form (as a logical consequence of the former incorrect conclusion), but it is basically right. The preacher states, without specifying the reason, that such a remarkable event remained without feast (part 3). He does not allow us to know how long such a situation continued, but it is certain that the event already belonged to the past. Especially relevant is the phrase "како... се видение... бысть без праздника (how this... vision... remained without feast)." Thus, the author knew both the fact of the vision and the fact that it remained without feast. Such a phrase would be impossible if he had been told about the event almost immediately and was thinking about how to commemorate it.

"...the feast was established not in Constantinople," continues Spasskij, "because in the prayerful address to the Theotokos it is said: 'In the same manner as Thou hast covered mercifully the people therein, coverest us (who are) Thy sinful servants by the cover of Thy wings.'” This conclusion, again, seems to me completely unjustified. The opposition "here/there" is natural if we are commemorating an event of the past and if we are commemorating throughout the whole patriarchate and the whole empire an event that took place in one church.

It is remarkable that the Prolog entry does not mention the word "Pokrov" as the name of the feast. The name that is meant seems to be

(53) Устави же ся таковыи праздник празновати месяца октября в 1 день, на память святаго апостола Анании.

(54) SpassKij 1898, 239. 
"Vision of Andrew and Epiphanius," with some non-obligatory and variable epithets. This is additional evidence that the Prolog entry goes back to or is identical with a document where the "author" of the feast was speaking in the first person.

\subsubsection{Relation to the Life of Andrew the Salos}

Those few scholars who studied the Prolog sermon on Pokrov were convinced of its Russian origin and, consequently, of its dependence on the tenth-century Life of Andrew the Salos..$^{55}$ Only Sergij Spasskij has pointed out that the scene of the vision of St Andrew in both the Greek original and the Slavonic version of his Life does not contain the words of the prayer of the Theotokos. ${ }^{56} \mathrm{He}$ noted that the text of this prayer, being a commonplace of the homiletic Pokrov tradition, does not have its source in the Life of Andrew the Salos. ${ }^{57}$

The Prolog description of the vision is shorter than that in the Life. It may have been produced as an abridgment of the latter account, but it did not necessarily originate in this way. There is absolutely no reason preventing us from considering it as an independent document going back to a tradition earlier than the tenth-century Life. Indeed, the Life is a typical Byzantine tenth-century hagiographic novel, roman hagiographique, of the same kind as, for example, the Life of Grigentios of Tafar or the Barlaam and Ioasaph. I have proposed to call this kind of novel a roman anthologique: it accumulates a great number of different sources and thus becomes a large anthology. ${ }^{58}$ There are serious reasons to consider an important part of the Life of Andrew, the so-called Apocalypse of Andrew the Salos, as a seventh-century text. ${ }^{59}$ In any case,

(55) Even Lennart Rydén accepted without discussion "the dogma of Vladimir origin" of the feast, and thus its dependency precisely on lines 37323758 of the Life: RYDÉN 1995, vol. 1, 188; cf. also his earlier article: RYDÉn, The Vision of the Virgin at Blachernae and the Feast of the Pokrov, 81-82.

(56) SpassKiJ 1898, 264.

(57) For the corresponding text of the Life, see: Moldovan 2000, 595-596 (Greek text of the recension closest to the Greek original of the Slavonic version), Moldovan 2000, 399 (Slavonic version), and RYdÉn 1995, vol. 2, 254/255 (txt/tr.).

(58) B. Lourié, The Tenth Century: From roman hagiographique to roman anthologique, Scr 4 (2008) 446-449.

(59) C. Mango, The Life of St. Andrew the Fool Reconsidered, Rivista di studi bizantini e slavi 2 (1982) 297-313 [reprint: Idem, Byzantium and Its Image: History and Culture of the Byzantine Empire and Its Heritage (London, 1984) (Vari- 
such Lives as that of St Andrew were not written by some tenth-century scribe at random. All these romans anthologiques were created as an accumulation of different available traditions around some unified theme. The traditions themselves are of different origins and different ages. Many such traditions are available through other sources independent of these Lives.

Thus, the mutual relations between the Prolog entry on Pokrov and the Life of Andrew the Salos are a priori unknown. The text of the prayer of the Theotokos may be a rhetorical addition of the epitomiser but it may also reflect traces of an independent tradition concerning the vision of Andrew. In any case, the Prolog entry is to be dated with no regard to the date of the Life of Andrew. An early date, such as from 907 to 911 , is by no means excluded.

\subsubsection{Author}

In Russian scholarship it became normative to repeat Spasskij's claim that the author of the Prolog entry on Pokrov was some Great Prince $^{60}$ (the senior among the Russian princes). But why a prince and not a metropolitan of Kiev? Why a secular ruler rather than the head of the Church? Spasskij's answer was that the Kievan metropolitans were Greeks who were quite aware that there was no such feast in Byzantium. Thus, according to Spasskij, their role was passive: the Church authorities simply accepted the proposal of the Great Prince.

In the Byzantine context, these reservations concerning the Church authorities are useless. It is normal that a sermon dedicated to the establishment of a new feast would be delivered by the head of the local Church. On the contrary, it would be quite unusual if the Church homilies had been delivered by a secular ruler. However, in Byzantium under Leo the Wise just such an unusual situation took place. The Emperor was a renowned Church rhetor.

Leo the Wise's collection of homilies (most probably edited by himself) belongs to his homiletic activity in the earlier half of his reign. It is known that in the later years of his rule, especially after the tetragamia affair, he became much less active as a rhetor. Nevertheless, it is certain

orum Collected Studies Series, CS191) Ch. VIII]; Mango criticised Rydén's earlier paper, L. Rydén, The Date of the Life of Andreas Salos, DOP 32 (1978) 129-155. Cf. Rydén's last response: Rydén 1995, vol. 1, 41-45.

(60) Spasskij 1898, 242. Other scholars, after Spasskij, attempted to propose some concrete names, including that of Andrew of Bogolubovo. 
that a portion of his homilies is now lost. ${ }^{61}$ Thus, his candidature is not to be excluded from the list of possible authors of the Prolog entry or its ultimate source (if this entry is a later epitome of some homily). The only other alternative is, of course, patriarch Euthymius - the emperor's spiritual father, with whom he had almost daily meetings when Euthymius became patriarch.

The Prolog entry is much shorter than a usual festal homily but, unlike other Synaxarium entries (and the Russian Prolog is no exception here), it is constructed as an account in the first person. Most probably, we have here an epitome of an earlier homily. Be that as it may, this does not concern our attribution of the original document, that is, the original sermon known to us through the Russian Prolog entry.

This original homily, whether or not it is identical to the Greek original of the Prolog entry, must be attributed to either patriarch Euthymius or Leo the Wise.

\subsection{Conclusion to the Byzantino-Russian Dossier}

The Byzantino-Russian dossier, and especially the part concerning BHG 1136d, supports Wortley's hypothesis. The feast of Pokrov certainly has a Byzantine origin, and its appearance under Leo the Wise at the time of the tetragamia affair (907-911) is especially likely.

There are three factors that point to this particular time:

1. The explicit mention in the Russian tradition;

2. The possibility of the early disappearance of the feast in Byzantium under Nicholas Mystikos (912-925) but its preservation in Rus';

3. The very nature of the troubles as mentioned in the source, especially in BHG 1136d and Pachomius Logothetos: not a danger

(61) On Leo's homiletical activity, see Th. Antonopoulou, The Homilies of the Emperor Leo VI (Leiden - New York-Cologne, 1997) (The Medieval Mediterranean, Peoples, Economies and Cultures, 400-1453, 14), here 71, cf. 26. On Leo's reign, see especially an old monograph still important in Church policy matters, Н. Попов, Император Иев VI Мудрый и его цзарствование в церковноисторическом отношении [N. Popov, The Emperor Leо VI the Wise and His Reign in the Church-Historical Aspect] (Moscow, 1892); see also H. Tougher, The Reign of Leo VI (886-912): Politics and People (Leiden-New York-Cologne, 1997) (The Medieval Mediterranean, Peoples, Economies and Cultures, 400-1453, 15). 
from external enemies or a civil war but rather disruptions resulting from moral sins. ${ }^{62}$

As to the third point on this list, let us recall the battles between the partisans of Nicholas Mystikos, who was deposed at the beginning of 907 (February or a bit later) and those who accepted the new patriarch, Euthymius. In about spring of 907 (not later than the summer), a council in Constantinople, with the participation of Rome and the Eastern patriarchates, confirmed the deposition of Nicholas and permitted Leo a fourth marriage. The same council convinced Euthymius to accept the patriarchal throne. These circumstances gave rise to an open conflict complicated by scenes of violence among the clergy and the faithful. The words of the preacher of BHG 1136d about the blaming of the clergy by the faithful would seem quite natural in such a situation.

It is interesting to add that the earliest Russian liturgical service on Pokrov seems to be a translation from Greek. ${ }^{63}$ This is not in conflict with the hypothesis of the Kievan origin of the service (as Michail Mur'janov has shown, the Kievan service to the Russian saints Boris and Gleb was also written in Greek and its Greek original is also $\left.\operatorname{lost}^{64}\right)$, but is natural for a feast of Byzantine origin.

Therefore, Wortley's hypothesis that the feast of Pokrov has a Byzantine origin is stronger. Stronger but not yet proven. Proof would require an analysis of the Byzantine prehistory of the feast and its date of 1 October. Given the chronology of the conflict of 907, autumn would be an appropriate time to establish a feast which is aimed at calming things down. But the exact date of 1 October needs to be explained on liturgical grounds.

And there is another problem that remains even in the Byzantine context: the feast, according to the Prolog entry, was established not immediately after the vision but at some later time. If so, it must be a modification of some pre-existing liturgical tradition. Such a pre-exist-

(62) In her recent study of the liturgical service for the feast, Pliukhanova notes that it contains "....an element of a litany on some concrete cause (элемент молебна по какому-то конкретному поводу)" but without the possibility of defining it exactly (Pliukhanova 2008, 446).

(63) Cf. Yusov 2009.

(64) М. Ф. Мурьянов, Из наблюдений над структурой служебных миней [From Observations on the Structure of the Liturgical Menaea] (1979), in: IDeм, История книжной культуры России. Очерки. Часть 2 (Moscow, 2008) (История книжной культуры России) 71-85. 
ing tradition is a prerequisite, for inventing a new feast which marks no contemporary event and relies on no liturgical tradition is akin to planting a tree in asphalt - it simply will not take root in such a void.

Thus, we must continue with a search for the Byzantine liturgical tradition that was reused in the feast of Pokrov on 1 October.

\section{Part Two: Armeno-Byzantina}

\subsection{Introduction}

Our next task is to understand why the feast of Pokrov was appointed on 1 October. As explained above, there must have been a liturgical tradition behind this choice. So far, it is not at all clear why the date of 1 October was chosen. The Life of St Andrew the Salos provides no date, and even the Prolog entry, which mentions 1 October as the date on which the feast was established, does not give this as the date of the vision itself.

It is possible that the task will be simplified by the fact that we have to explore the origins of a liturgical cycle comprising, at least, the next day, 2 October, which marks the commemoration of St Andrew the Salos. In the Life of St Andrew it is clearly stated that he died on $28 \mathrm{May}^{65}$ and this is the only date of his commemoration known to the Synaxarium of Constantinople (a late recension only; the earliest recensions, which are close to the ninth-century archetype, do not include his name at all). ${ }^{66}$ On Russian soil, the commemoration of 28 May is unknown, despite the presence of this date in the Slavonic version of the Life of Andrew the Salos. ${ }^{67}$ It is clear that the commemoration of St Andrew on 2 October is a part of the Pokrov liturgical cycle; it is not

(65) RYdÉn 1995, vol. 2, 302.4388-4391; Moldovan 2000, 630.6162-6164.

(66) Synaxarium CP, cols. 713-714. For the date of the earliest recension, see especially A. Luzzi, Studi sul Sinassario di Constantinopoli (Rome, 1995) (Testi e studi bizantino-neoellenici, 8) 5-6, n. 3.

(67) Moldovan 2000, 450.6162-6165. Moreover, this date became known in Russia together with the Slavonic translation of the Stišnyj Prolog, i.e. the translation of the Calendar in Verses of Christophorus of Metilena, eleventh century [E. Follieri, I Calendari in metro innografico di Cristoforo Mitileneo (Bruxelles, 1980) (SH, 63)]; the South Slavonic translation of the fourteenth century became available in Russia not earlier than the late fourteenth century: A. А. Туридов, К истории Стишного Пролога на Руси [А. A. Turilov, Toward the History of the Stišnyj Prolog in Rus'], Аревняя Pусь (2006) Nr 1 (23). 36-39. 
so clear, however, whether the feast of Pokrov was established from the very beginning as a cycle including 2 October, or whether this commemoration of St Andrew represents a later development.

The eve of 1 October, i.e. 30 September, is the feast of a saint whose importance for Byzantium was especially great in the late ninth and the early tenth centuries: St Gregory the Illuminator of Armenia. A date in this chronological vicinity may have been chosen deliberately, especially if it is true that the feast of Pokrov was established in the first years of the tenth century. This is just another reason to go deeply into the study of the ninth- and tenth-century cult of St Gregory in Constantinople, although this cult is, regardless, important for the understanding of the Byzantine state ideology of the Macedonian period.

\subsection{The Discovery of the Relics of St Gregory during the Patriarchate of Photius}

\subsubsection{Historical Context}

The commemoration days of St Gregory the Illuminator were never connected to the day of his death because the latter was never known. This Moses of the Armenian people died in the same manner as the biblical Moses, that is, in an unknown place and on an unknown date. There were two principal sources of his commemoration dates: his vision of Christ and the Heavenly Tabernacle over the future see of Etchmiadzin, in Vałaršapat (the name Etchmiadzin means "Descended the Only-Begotten" and it comes from this vision) and the days of discovery and translation of his relics.

For the early Macedonian period, there was one especially important (re)discovery of St Gregory's relics together with those of his companions Gaiane and Rhipsime (Hripsime) and also with the relics of the martyrs Sergius and Bacchus; this took place in Constantinople purportedly at the time of Patriarch Photius. The detailed account of this event is preserved in Armenian only (BHO 339-340). It was composed by an Armenian Church official in 878/879 (year 327 of the Armenian era ${ }^{68}$ ) for the Armenian prince of princes Ašot Bagratuni (820-891), who ruled as King Ašot I from 886. This account is based on

(68) Thus in BHO 340. Two other editions (see below) have the year 325 of the Armenian era, which corresponds to 876/877 (reflecting the common confusion between the numbers 5 and $7, \mathrm{E}$ and $\mathrm{E}$, in Armenian writing). For "327" as the genuine reading, s. GreEnwood 2006, 188-189, n. 8 et passim. 
the oral description made by the Byzantine ambassador, the eunuch Nikodemos, who presented himself as the officer responsible for the whole process of the discovery. It is this account that is echoed in the thirteenth-century Armenian chronicle of Vardan and other late Armenian sources. ${ }^{69}$ The most probable author of the written text is the Armenian Catholicos Georges II of Garni (878-898). ${ }^{70}$

It is beyond any doubt that the document as it stands represents the Church policy of Patriarch Photius, who worked strenuously for the union with the Armenian Church and whose mutual relations with the Armenian ecclesiastical and secular authorities were especially close and warm. ${ }^{71}$ The fact that the Byzantine cult of St Gregory the Illuminator received, in the early Macedonian period, a new impetus is proven. ${ }^{72}$ Its political background is more or less known, too. Basil I was an Armenian, and Photius (himself partially of Armenian descent) was directly involved in promoting Basil's depiction as a ruler from the dynasty of Arshakids, a lineage going back to the old Armenian kings. It was probably Photius himself who composed the genealogy tracing

(69) The account was first studied as a hagiographical document and translated into a European language (French) in van EsBroeck 1971; he knew only one edition, of 1902 (= BHO 340 while van Езвовск 1971 mistakenly identifies it as $B H O$ 339). In fact, there are three independent editions (s. references below, n. 94) of this text based on three different manuscripts (the edition from 1901 by L. M. Ališan = BHO 339; from 1902 in the Etchmiadzin periodical Ararat = BHO 340; and from 1954 by N. Połarean, not in BHO). Oddly enough, van Esbroeck ignores BHO 339 completely, focusing instead on Peeters 1942. Peeters quotes BHO 339 only (apparently with no access to BHO 340). For the manuscript tradition and an English translation taking into account the different readings, see GreENwood 2006, where he also lists two unpublished manuscripts from Matenadaran, Yerevan.

(70) van Esbroecck 1971, 404.

(71) For a general outline but with no specific attention to our document, see: I. Dorfmann-Lazarev, Arméniens et byzantins à l'époque de Photius: deux débats théologiques après la triomphe de l'Orthodoxie (Lovanii, 2004) (CSCO, 609, Subs 117).

(72) Cf. one interesting fact among others: Gregory the Illuminator was included by Photius in a new series of mosaics in St Sophia representing the same holy hierarchs as in the epistle of Photius to Ašot; see S. Der NersesSIAN, Les portraits de Grégoire l'Illuminateur dans l'art byzantin, Byzantion 36 (1967) 386-395 [repr. in EADEM, Études byzantines et arméniennes. Byzantine and Armenian Studies, vol. 1 (Louvain, 1973) (Bibliothèque arménienne de la fondation Calouste Gulbenkian) 55-60]. 
Basil back to the Arshakid king Trdat III the Great (ca 287-330), the first Christian king of Armenia. ${ }^{73}$ This Arshakid genealogy of the Macedonian dynasty became the foundation of the imperial official ideology.

Thus, the political and ecclesiastical meaning of the rediscovery of the relics of St Gregory and his companions in Constantinople is clear. What is not so clear, however, is the precise date and the precise place of the discovery.

\subsubsection{Precise Place: $\tau \dot{\alpha}$ Ka@ı $\alpha$ võ Monastery near Blachernae}

The Armenian account BHO 340 (based on a manuscript dated to 1454) studied by van Esbroeck localises the event at an unspecified Holy Trinity church in the region of Constantinople called "Garin." The Holy Trinity Church in that district was, in fact, the principal church among three located there. The second church was dedicated to the protomartyr St Stephen and the third to the Holy Cross. Thus, van Esbroeck identified this region as the quarter $\tau \dot{\alpha} \mathrm{K} \alpha \varrho \iota \alpha$ vov near Blachernae $^{74}$ with its monastery of Staurakios ${ }^{75}$ whose title was comprehended as "of the Holy Cross." Such a mistake was likely not only by the Armenian author, apparently unaware that the monastery was named after the emperor Staurakios (who died at the monastery in 811 shortly after having been tonsured), but the error might also have been transmitted by his Byzantine informant, given that the name of the monastery was variously garbled in the Byzantine sources. One such error includes the form $\tau \dot{\alpha} \Sigma \tau \alpha v \varrho \alpha \kappa \alpha ́$, which apparently has no connexion to Staurakios and refers instead to "Cross."76 Indeed, the prin-

(73) Cf. especially K. Н. ЮзБАшян, Армянские государства эпохи Багратидов и Византия IX-XI вв. [K. N. Youzbashian, The Armenian States of the Bagratid Epoch and Byzantium of the ninth-eleventh centuries] (Moscow, 1988) 100105; A. Sснміnск, The Beginnings and Origins of the "Macedonian" Dynasty, in: R. Scott, J. Burke (eds.), Byzantine Macedonia: Identity, Image and History. Papers from the Melbourne Conference, July 1995 (Melbourne, 2000) (Byzantina Australiensia, 13) 61-68.

(74) On this quarter "voisin de l'église des Blachernae," see R. Janin, Constantinople byzantine. Développement urbain et répertoire géographique (Paris, $\left.{ }^{2} 1964\right) 367$.

(75) See below Note 1 on this identification of the two monasteries, $\tau \dot{\alpha}$ Ka@ı $\alpha$ voṽ and of Staurakios.

(76) van Esbroeck 1971, 405. On the monastery of Staurakios, see Janin 1969, 470-471. Here I have elaborated a bit on van Esbroeck's overly succinct phrase "...un monastère de la Trinité, appelé Staurakion ou de la Croix." 
cipal church of the Staurakios monastery was that of the Holy Trinity. There is nothing known about the Church of St Stephen here, but its existence does not contradict the known facts.

Two other Armenian editions used by Timothy Greenwood (based on manuscripts dated to 1224 and 1737) complicate the matter even more. Both of these sources refer to this region not as "Garin" but as "Dap'n," that is Daphne ( $\Delta \alpha \phi v \eta)$, which is a different district in Constantinople. The confusion between the two quarters is easily accounted for by Armenian writing, where qunhi and nuwhi look very similar. But which of the two readings is correct? Greenwood argues for "Garin" but only "on the balance of probabilities". ${ }^{77}$ His main arguments in favour of "Garin" are the dedications of the corresponding churches. The sanctuaries of the palace of Daphne were dedicated to St Stephen, the Holy Trinity, and the Theotokos, with no dedication to the Holy Cross. Moreover, the Holy Trinity in Daphne was an oratory

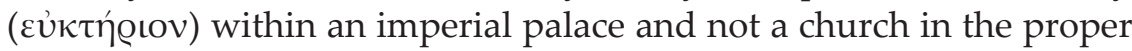
sense.

Greenwood's only argument in favour of "Daphne" is the reference, in our account, to an unknown papias Aetios as the overseer of the church. The title papias is possible only if the church belonged to an imperial palace. To date, the offices of papias are known for the Great Palace, the Magnaura palace, and the Daphne palace, the latter being instituted by Michael III $^{78}$ (the eunuch Nikodemos dates the events he reports to Michael's reign).

Of course, this does not mean that there were no specific papias for $\tau \dot{\alpha} \mathrm{K} \alpha \varrho \mathbf{\alpha} \alpha \mathbf{v} \tilde{v}$, where an imperial palace is also known. Three of the four daughters of Empress Theodora, according to the Life written in the late ninth century, were secluded, in 856 or shortly thereafter, in the

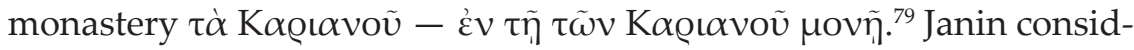
ers this Life as an authoritative source, and thus attempts to explain the presence of a monastery in this quarter despite the fact that the other (but later) sources are silent about it, referring only to an imperial

(77) Greenwood 2006, 183-184. Peeters 1942, 120, mentions only “Daphne," apparently unaware of the reading of BHO 340. Van Esbroeck disregards both $B H O 339$ itself and Peeters's quotation from it, although he often refers to Peeters's paper.

(78) A. K[azhdan], Papias, in: IDem (ed.), The Oxford Dictionary of Byzantium, vol. 3 (New York-Oxford, 1991) 1580.

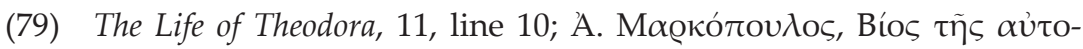

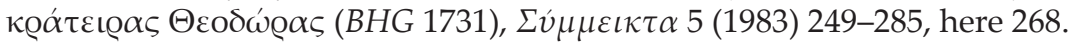


palace in this area. ${ }^{80}$ Greenwood seems to be right in claiming that this interpretation of our text "...affords a neat solution to this long-standing conundrum, namely that the imperial palace $\tau \dot{\alpha}$ Ko@ı $\alpha$ vov included at least one church within its boundaries, dedicated to the Holy Trinity." ${ }^{81}$ Janin suggested either that Michael III transformed an imperial palace into a monastery for his sisters or there was a monastery near the palace. The first supposition seems unlikely to me given that the later authors refer to a palace and not a monastery in $\tau \dot{\alpha}$ K $\alpha \varrho \iota \alpha v o \tilde{v}$. The interpretation that best fits the sources would be a monastery in which the nuns were members of the emperor's family located within the confines of the imperial palace. It is very probable that the monastery ceased to exist sometime in the tenth century.

The argument in favour of the $\tau \dot{\alpha} \mathrm{K} \alpha \varrho \iota \alpha$ vo v locale relies upon the insistence of the Armenian account, which says that the discovery of the holy relics is celebrated in Constantinople on the fifth Saturday of Lent. ${ }^{82}$ In fact, the feast of the fifth Saturday of Lent is the so-called Saturday of Akathistos, and our Armenian account, for some reason, apparently confuses this feast with the commemoration of the discovery of the relics. The Typicon of the Great Church in the oldest, tenthcentury, manuscript prescribes for this day a pannychis (whose basic element was a vespers service) in the Blachernae Church, with orthros (matins) in the Holy Soros and the Eucharistic liturgy in the Great Church (St Sophia). ${ }^{83}$ The Saturday of Akathistos was established after the siege of Constantinople by the Avars (626). The Blachernae Church was its main sanctuary because as the faithful gathered here to pray to the Theotokos, the enemy fleet sank off the Blachernae wall. ${ }^{84}$ Regardless of the reasons for the confusion in our Armenian account, ${ }^{85}$ such a confounding with the Saturday of Akathistos is especially likely if

(80) JANin 1969, 278.

(81) Greenwood 2006, 183.

(82) See the next section for the Lenten time as the date of this celebration.

(83) J. Mateos, Le Typicon de la Grande Église. Ms. Saint-Croix, $n^{\circ} 40$, $\mathrm{X}^{e}$ siècle. Introduction, texte critique, traduction et notes. T. II, Le cycle des fêtes mobiles (Rome, 1963) (OCA, 166) 52/53-54/55 (txt/tr.).

(84) On this, see: L. M. РецtomaA, The Role of the Virgin Mary at the Siege of Constantinople in 626, Scr 5 (2009) 284-299.

(85) In the Armenian rite, although from an unknown epoch and only in some sources, the fifth Saturday of Lent is the commemoration of Gregory the Illuminator's Entry into the Cave (cf. examples of manuscripts quoted in Akinean 1947, col. 607-610). This Armenian festivity could interfere, in our 
the relics were discovered near the Blachernae Church and not in the Daphne palace.

Locating the events of our account in Daphne would presuppose a grave error on the part of the narrator, who places the discovery of the holy relics in the main church of the Holy Trinity, a location that surely could not be confused with an oratory within the emperor's palace. Our Armenian account seems to state clearly enough that the event took place in one of the three separately standing churches and not within any palace. Because he thinks this account is a late composition, Greenwood considers it to be somewhat confused; as we will show in the next section, such problems arose from the over-exactitude of this source rather than from any later misunderstanding. Thus, Greenwood's conclusion that the reading "Garin" is the genuine one must be repeated with certitude.

\section{Note 1: van Esbroeck's identification of the monastery $\tau \dot{\alpha}$ K $\alpha \varrho \iota \alpha v o \tilde{v}$ with the monastery of Staurakios}

There is a specific problem in van Esbroeck's identification of the monastery $\tau \dot{\alpha} \mathrm{K} \alpha \varrho \iota \alpha v$ ov with the monastery of Staurakios. In this passage, van Esbroeck referred to Janin's entry on the monastery of Staurakios, apparently forgetting that Janin wrote that "[a]ucun document n'indique l'emplacement de ce monistère." 86 Based on my personal acquaintance with van Esbroeck, I take the liberty of suggesting that this identification belongs to van Esbroeck himself - he may have forgotten that he himself, not Janin, originated this argument and thus did not explain his reasoning in his paper. Thus, I will try to retrace his steps.

In the Byzantine sources, we have absolutely no data concerning the dedication of the monastery $\tau \dot{\alpha}$ K $\alpha \varrho \iota \alpha$ vo v and its sanctuaries. Thus, the data of our Armenian account are of prime importance. They show that the principal church of the monastery was that of the Holy Trinity. Such a dedication was not common in Constantinople ${ }^{87}$ so an attempt to identify this monastery with another one known from other sources is reasonable. There are three important reasons in favour of the identity of the two monasteries against two less serious reasons contra.

Armenian account, with the commemoration of the discovery of the relics in Constantinople.

(86) Janin 1969, 471; cf. van Esbroeck 1971, 405.

(87) The data in JANIN 1969 are statistically representative. In Janin's lists we have 136 entries for the Theotokos, 36 for St John the Baptist, 12 for St Stephen, and only 7 for the Holy Trinity. 
(1) Among Janin's seven entries listing Holy Trinity sanctuaries there is one associated with the monastery of the Holy Trinity of Staurakios; its location is unknown to Janin. The dedication of this monastery is identical with that of the main church of $\tau \dot{\alpha}$ K $\alpha \varrho \iota \alpha$ vo v according to our Armenian document;

(2) The second coincidence can be derived from the very name Staurakios, especially in the form $\tau \dot{\alpha} \Sigma \tau \alpha v \varrho \alpha \kappa \alpha \dot{\alpha}$. The name of the monastery can be read (and certainly was read by some in Byzantium) as the monastery of the Holy Trinity of the Cross. This makes it possible to consider one of the monastery's churches as being dedicated to the Holy Cross, as stated in our Armenian account;

(3) The St Stephen church mentioned in the Armenian account is unattested in the Staurakios monastery but its existence here is admissible;

(4) However, in the Staurakios monastery there was an oratory

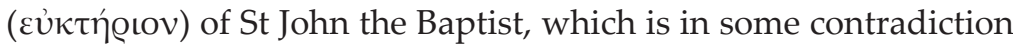
to our Armenian account. Indeed, the list of the three churches of "Garin" makes no sense if it is not exhaustive for this quarter. Nevertheless, this contradiction appears less acute if we take into account that the Armenian list enumerates only the churches, whereas the sanctuary of St John the Baptist was an oratory;

(5) Finally, the last traces of the monastery of Staurakios can be found in the De ceremoniis of Constantine Porphyrogenete in the middle of the tenth century (references to it in the later chronicles are dedicated to events of the early ninth century), which corresponds to the disappearance of the monastery $\tau \dot{\alpha} \mathrm{K} \alpha \varrho \iota \alpha v o \tilde{v}$ about the same time, most probably before the end of the tenth century.

Taken together, reasons (1), (2), and (5) are much stronger than reasons (3) and (4), and this is especially important given that the dedication to the Holy Trinity was uncommon in Constantinople. We have a relatively narrow set of church complexes that included a Holy Trinity sanctuary, and, within this set, we have a series of important agreements and much less important disagreements between one of these complexes and that of our Armenian account. Unless there was an unattested complex even more similar to that of our Armenian account, we have to assume that the

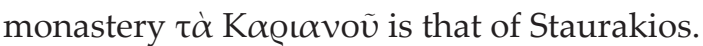

\subsubsection{Date: between 862 and 867}

The date of the rediscovery of the holy relics in the eunuch Nikodemos' account is somewhat strange: it appears during the reigns 
of the emperors Michael and Theodora but also under patriarch Photius. Patriarch Photius (858-867, 877-886) started his first patriarchate when Theodora had already ceased to be regent (856) and had been removed from court (August or September 858). Theodora's retirement was likely a precondition of the deposition of patriarch Ignatius in November $858^{88}$ and, consequently, of the enthronment of Photius on 25 December. Both van Esbroeck and Greenwood consider such dating as an anachronism, although explain it in different ways.

Greenwood's approach is somewhat overcritical: "Rather than interpreting the inclusion of Photius in the account as simply a mistake, it seems to me that it was deliberate and that it reveals the influence of Photius in the composition of the text." ${ }^{89}$ In other words, Greenwood supposes here a deliberate falsification inspired by Photius himself at the beginning of his second patriarchate (which began on 22 October 877), when the Armenian text was composed. Greenwood's point of view does not allow him to date precisely the discovery of the relics, but he argues for the dating of the historical core of the account to the period when Theodora was regent, from 842 to 856 . In fact, Greenwood writes along the same lines as Peeters, whose conclusions were almost the same while even more critical regarding the historicity of the account..$^{90}$

Van Esbroeck proposes the exact date of 26 May 843. ${ }^{91}$ The only anachronism he acknowledges in our text is that Photius is named as patriarch. Nevertheless, according to van Esbroeck, “...il se peut qu'il ait participé à la procession avant avoir accédé aux charges ecclésiastiques suprêmes." 92

Both van Esbroeck and Greenwood overlook a short period when Photius was patriarch at the same time that Michael and Theodora were the emperors, from 863 (or even 862), when Theodora returned to the court, ${ }^{93}$ to 23 September 867 , when Michael was murdered. The

(88) J. Herrin, Women in Purple. Rulers of Medieval Byzantium (London, 2001) 227.

(89) Greenwood 2006, 184.

(90) Peeters 1942, 121.

(91) van Esbroeck 1971, 404-405.

(92) van EsBroeck 1971, 404.

(93) On the return of Theodora to the court, see: F. Нirsch, Byzantinische Studien (Leipzig, 1876) 66 (first observation of the fact, imprecise in some details); J. B. Bury, The Ceremonial Book of Constantine Porphyrogenetos, Eng- 
discovery of the holy relics described in our account must be dated to this interval and the account itself must be considered as free from any errors in chronology.

\subsubsection{The Date of the Liturgical Commemoration}

The only scholar who paid due attention to the date of the liturgical commemoration was van Esbroeck. Unfortunately, an error in his translation compromised his efforts in this field. The relevant passage was translated by Greenwood, too, with no formal error but nevertheless incorrectly. Neither translation grasped the relevant Armenian liturgical term.

The Armenian text reads as follows: Es hpuqnpdiguid uuughuppu

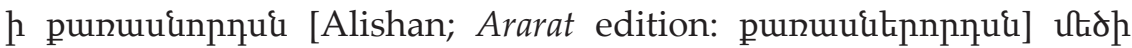

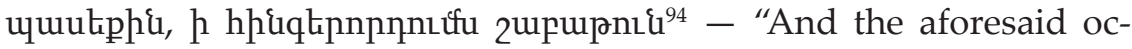
curred during the Lent of great Easter, on the fifth Saturday." 95 The key word here is punuuunnnp/punuuutinnpnp, which is the literal

lish Historical Review 22 (1907) 209-227, 417-439, here 434 (the date of Theodora's return to the court and her regaining of the title of Augusta based on her role in the court ceremonial); IDEM, A history of the Eastern Roman empire from the fall of Irene to the accession of Basil I., A.D. 802-867 (New York, 1912) 117, n. 3 and 284, n. 4; Herrin, Women in Purple..., 228 and 293, n. 99 and 100. Pope Nicholas I addressed Theodora as Augusta in his letter to her in 866.

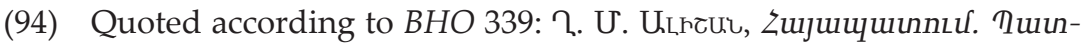

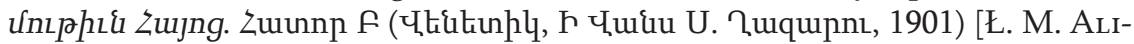
ŠAN, Antiquities. The History of Armenia, vol. 2 (Venice, San Lazzaro Island, 1901)] 42-48, here 48, and BHO 340: Tuunún pphiq junuqu qhıun \& 2 huupurg 9phqnph Zujng Utioug Lnıuuınn Relics of Gregory the Illuminator of Great Armenia], Unupuin [Ararat] 35 (1902) 1178-1183, here 1182. The 1954 edition (unavailable to me), according to GreEnwood 2006, has here the same reading.

(95) Greenwood's translation modified; Greenwood translated the passage as "the forty days" instead of "the Lent" (Greenwood 2006, 181). "Forty days" is here an explicative translation but rather unhelpful because the Armenian text uses a precise liturgical term. Van Esbroeck translated "...dans les quarante jours après la grande Pâque, le cinquième samedi," and then calculated the date of the discovery as the year when the memory of Sergius and Bacchus on 26 May coincided with the fifth Saturday after Easter (vaN Еsвrовск 1971, 404-406). These calculations are of course unacceptable but the very idea that the additional commemoration of Sergius and Bacchus in May has some connexion with the discovery of their relics in Constantinople is still worthy of attention. 
rendering of the Greek term $\tau \varepsilon \sigma \sigma \alpha \varrho \alpha \kappa o \sigma \tau \eta$ which means the 40-day fast period. Thus, the Armenian account establishes the commemoration on the fifth Saturday of Lent, which is known in the Byzantine rite as the Saturday of Akathistos.

The same date is confirmed by Vardan the Great, who finished his Historical Compilation in 1267: "Nikit [sic "Nicetas" instead of the correct "Nikodemos" ${ }^{\prime 96}$ ] reported: "We found the relic of St Gregory the Illuminator during Lent [' $\mathrm{h}$ junn hugud, lit., "in salting of breads"] in the fifth week on Saturday,' which they made a festival." ${ }^{97}$ Kirakos Ganjakec' $i$, who studied with the same teacher as his close colleague Vardan, included the same story but in a more imprecise fashion in his History, which covers the period to $1265 .{ }^{98}$ Neither historian mentions the relics of either Sergius and Bacchus or of Gaiane and Rhipsime.

Although it is scarcely possible that the discovery of the relics was commemorated on the Saturday of Akathistos, it is nevertheless a com-

(96) The year in the corresponding fragment is also indicated incorrectly: 325 of Armenian era instead of 327.

(97) R. W. Thomson, The Historical Compilation of Vardan Arewelc'i, DOP 43 (1989) 125-226, here 186. Armenian text: U. EUrı, Utidh પupquiuu]

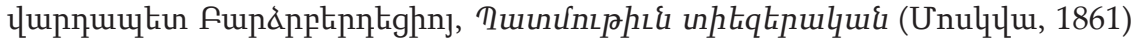
[M. Emin, Vardan the Great Barjrberdc'i, The Universal History (Moscow,

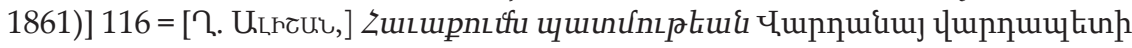

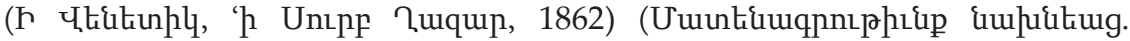
Tuunuuuqhpp Zuung) [<ヒ. AlišAn, $>$ The Historical Compilation of Vardan the vardapet (In Venice, in San-Lazzaro, 1862) (Ancient Literature. Historiography of Armenia)] 85. There is no critical edition of this work by Vardan. The edition by Ališan is based on two early manuscripts, one of which is to be dated before 1304 and written by Step'anos Siunec' $i$, who was a great historian himself. The manuscript background of the editio princeps by Emin goes back to the fifteenth century. In the Armenian rite, Lent is called "the fast of salt and bread," unnıhughg uuhp, because the faithful limit their meal on the feria to salted bread only (I am grateful for this clarification to Alexandr Kananyan and to Fr Ghevond, vardapet in Jerusalem).

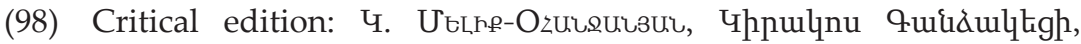

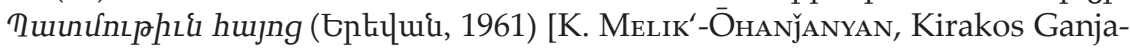
kec'i, The History of Armenia (Yerevan, 1961)] 14; translation by R. BEDrosian (1986), online publication http://rbedrosian.com/kg2.htm, p. 11: “An imperial eunuch came and related all this to King Ashot, and when he heard it, he glorified God and instituted a feast of Saint Gregory on that day, Saturday in the sixth week of Lent. This feast is observed to this day." The eunuch is anonymous here, the year is not indicated, and the festival is placed on the sixth (not fifth) Saturday of Lent, although not in Byzantium but in Armenia. 
prehensible error given the fact that the Church of the Holy Trinity in $\tau \dot{\alpha}$ K $\alpha \varrho \iota \alpha$ vov was located near the Blachernae Church, where the Saturday of Akathistos was one of the most important local feasts. Indeed, the events described in the Armenian account are hardly possible on a day when a great feast was celebrated in almost the same location.

Van Esbroeck's means of determining the genuine commemoration date can be at least partially invoked, and we can also be guided by the commemoration days for Sergius and Bacchus as well. Indeed, we have in Constantinople an additional day dedicated to their memory apart from the normal date on 7 October. ${ }^{99}$

The Constantinople Synaxaria contain an additional commemoration of Sergius and Bacchus on 26 May (with variants on 27 and

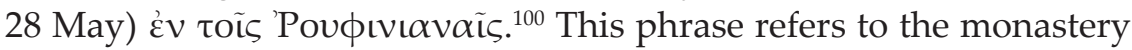
created in about 394 near Chalcedon by Claudius Rufinus, a minister of Theodosius the Great. ${ }^{101}$ This location of the feast is explainable by the activity of the anchoret John ( $+c a$ 877) who was appointed under Basil I (about 867) as the hegumen of the famous monastery of Sergius

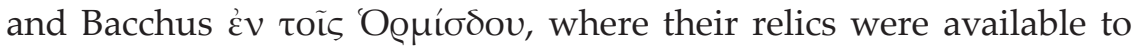
pilgrims. His Life by Joseph the Hymnographer is preserved in a Georgian version only. ${ }^{102}$

(99) For the hagiographical dossier of Sergius and Bacchus and their commemoration date on 7 October, see E. K. Fowden, The Barbarian Plain. Saint Sergius between Rome and Iran (Berkley-Los Angeles-London, 1999) (The transformation of the classical heritage, 28), esp. 8, n. 1.

(100) Synaxarium $C P$, cols. 709, 713.

(101) Janin guesses that "Rufinianes" is a quarter of Constantinople that may be located on the shore facing the Prince Islands, but van Esbroeck in 1971 was unable to suggest a specific location, stating that nothing certain was known. However, in his 1996 article van Esbroeck recalled a forgotten study by J. Pargoire dedicated to the monastery: J. PARgoire, Rufinianes, BZ 8 (1899) 429-477; cf. M. van Esbroeck, La Vie de Saint Jean higoumène de Saint Serge par Joseph le Skevophylax, Oriens Christianus 80 (1996) 153-166, here 155. Pargoire demonstrated that the monastery was situated three miles to the east of Chalcedon.

(102) On this Life, see K. KeKelidze, Un monument inconnu de la littérature byzantine en version géorgienne, Bedi Kartlisa 19-20 (1965) 61-68 (I am grateful to D. Kashtanov for a copy of this paper); it is a translation from Kekelidze's Russian edition: К. КекЕлидзЕ, Неизвестный памятник ви-

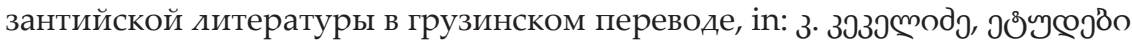

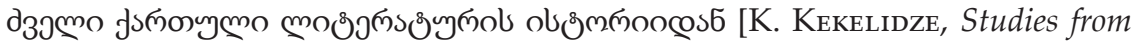
the History of the Old Georgian Literature], VIII (ononmobo, 1962) 244-255 (first 
Van Esbroeck explained convincingly why the monastery of Rufinianes became a place associated with the cult of Sergius and Bacchus using, on the one hand, the different known dates of commemoration of these saints, and, on the other, the dates associated with hegumen John. The monastery also became a place of commemoration of John himself, which is natural if he used this place as a silent retreat, especially in his final days. ${ }^{103}$

There is, however, a problem. The Life of hegumen John contains another story about a discovery of the relics of Sergius in Constantinople, a story that is different from that of our previous Armenian source. In this source, it is stated $(\S 15)$ that John discovered many relics of saints including, among others, those of St Sergius (without Bacchus): “...Et en allant ici et là, il découvrit beaucoup d'autres reliques de saints, car les saints le lui présentaient avec diligence comme à un véritable saint. Bien plus à Constantinople, dans le sanctuaire de saint Serge, il découvrit lui-même les reliques cachées depuis de longues années, et que quelques hommes étourdis avaient cachées ainsi ignominieusement sous terre." 104 The "sanctuary of St Sergius" mentioned here is none other than the main church of the monastery where John was the hegumen. The date of the discovery is not specified but it seems to imply that it occurred during the period of his hegumenate. The differences with the Armenian account encompass the time, the place, the identity of the discoverer, and the contents of the discovery (no relics other than those of Sergius). Unfortunately, van Esbroeck accepts these data

published in 1955). The text is published by Kekelidze with an introduc-

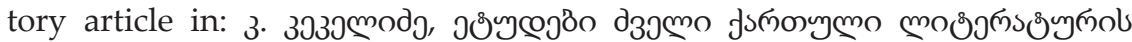
obsmmoocs5, III (onomolo, 1955) 251-270, the text on p. 260-270. Translated in van Esвroeck, La Vie de Saint Jean higoumène..., 159-166. The hagiographer called himself "Joseph the Skeuophylax" and is identified as Joseph the Hymnographer by Kekelidze. Joseph was appointed skeuophylax by Patriarch Ignatius at the beginning of his second patriarchate, not earlier than 867 (not during his first patriarchate, as Kekelidze thought); cf. A. K[AZHDAN], D. C[onomos], N. P[atterson] Š[evČEnKo], Joseph Hymnographer, in: KazHDAN (ed.), The Oxford Dictionary of Byzantium, vol. 2, 1074. JANIN 1969, 451-454, accepts uncritically the data of the Georgian source (without discussing or even naming the source, and with a typo in the reference to Bedi Kartlisa, cf. JANin 1969, 452 et n. 9: "1955" instead of "1965").

(103) van Esbroeck, La Vie de Saint Jean higoumène..., 155-156.

(104) Translation from van Esвroecк, La Vie de Saint Jean higoumène..., 163. 
uncritically and without any comment; ${ }^{105}$ by 1996 he may have forgotten his 1971 study, although, in a different way, his previous statement that the May dates of the commemoration of Sergius and Bacchus correspond to the discovery of their relics in Constantinople still holds. Thus, the problem passed unresolved and unobserved.

I think that there are serious reasons not to believe in the version of the Life written by Joseph the Hymnographer. The story is contained in the section of the Life ( $\S \S 1-16$ ) in which Joseph was relying on his anonymous oral informer from the monastery of John (in the remaining section, he was writing as an eyewitness). ${ }^{106}$ His account is very general and rather vague. The implied date of the discovery, although different, is not very remote from that of the Armenian account (not earlier than 867 vs not later than 865, respectively). Both hegumen John and Joseph the Hymnographer belonged to the Ignatians, and in their milieu, the good deeds of Photius during his first patriarchate would scarcely have been acknowledged. All these factors point to the attribution to John as the discoverer of the relics as a pious local tradition from John's monastery. All the details are obliterated and a little anachronism is overlooked, but the honour of finding the main relics of the monastery is reattributed to the only person and the only place which were really worthy - the monastery of Sergius and Bacchus and its hegumen, who was already famous for his ability to discover the relics of saints.

In contrast, the Armenian account is quite detailed, and its author, eunuch Nikodemos, was a participant in the events he describes. He was not especially interested in the relics of Sergius, and he thus had no need of inventing such detail. Moreover, according to the synaxaria, there was no specific feast of Sergius and Bacchus in this monastery outside of their commemoration on 7 October. ${ }^{107}$ It is thus unlikely that any real discovery of the relics took place here: otherwise, its date would be marked as a feast, at least on the local level. And, finally, the common veneration of the relics of Gregory the Illuminator and

(105) VAn Esbroecк, La Vie de Saint Jean higoumène..., 156: “Si quelqu'un du avoir trouvé l'idée de faire au printemps une Panégyrie des saints Serge et Bacchus aux Rufiniennes, qui ne devaient pas être très fréquentées après la crise iconoclaste, c'est assurément l'higoumène de Saint-Serge qui avait retrouvé leurs reliques."

(106) van Esbroeck, La Vie de Saint Jean higoumène..., 155.

(107) See, for a general context, JANIN 1969, 451-454. 
Sergius is a historical fact going back to the realities of Armenia in the seventh century.

The joined veneration of St Sergius and St Gregory the Illuminator can be traced back to the activity of the Armenian Catholicos Nerses III Šinoł ("the Builder") shortly after 642; he was the creator of their common sanctuary in Vałaršapat which contains the relics of both saints. This Catholicos of the epoch of the Monothelite union, who was in full communion with the Chalcedonian Church of Constantinople, is the one most likely responsible for the translation to Constantinople of the parts of the relics that were rediscovered in the ninth century. ${ }^{108}$ The rediscovery of the relics at this time seems natural, especially if they had been deprived of their identifying inscriptions during the Iconoclastic period, which was a hard time for the veneration of saints' relics. (The miracle of their rediscovery described in the Armenian account depicts the identification of relics of previously unknown saints but does not describe the discovery of the relics themselves - the actual relics were preserved in the Trinity Church from a remote period.)

Thus, it is reasonable to accept 26 May (or 27-28) as the date of the discovery of the holy relics in the Holy Trinity Church. Such a variation of the date in the Synaxaria is especially natural if the original feast included three days corresponding to the three groups of saints (Gregory, Gaiane, and Rhipsime on the one hand, and Sergius and Bacchus on the other), from 26 to 28 May.

All these considerations seem to me sufficient to conclude that Joseph's version of the events is erroneous: it detaches the finding of Sergius' relics from the other relics found at the same time (even from the relics of Bacchus! ${ }^{109}$ ) and ascribes the finding to John, in whose monastery the relics of Sergius were eventually deposed.

The disagreement between the two accounts emerged from the fact that the relics of Sergius had been translated to the monastery of Sergius and Bacchus from the place where they had been discovered several years before. We can therefore affirm our previous conclusion that 26-28 May are the days of the commemoration of the discovery of the holy relics in $\tau \dot{\alpha} \mathrm{K} \alpha \varrho \iota \alpha v o \tilde{v}$.

(108) For a detailed study, see van EsBroeck 1971, 406-411.

(109) The Life of John does not mention the relics of Bacchus in the monastery. The Russian pilgrim in 1200, Antony of Novgorod does not mention them either, but other pilgrims mention here the relics of both Sergius and Bacchus (s. JANIN 1969, 453). The earliest mention of Bacchus' relics is contained in the account of an anonymous Englishman ca 1190. 
It is especially interesting to ask whether the proclamation of the future Basil I as co-emperor on 26 May 866 was in any way connected with the new feast of Gregory the Illuminator on the same day. ${ }^{110}$ The ceremony was performed when Basil persuaded Michael III to make him a co-emperor after the murder of caesar Bardas on 21 April 866. It is logical, therefore, that a date shortly thereafter would have been chosen for the ceremony. The source providing a detailed account of the ceremony is Symeon Logothetos (who wrote after 948 and certainly before 1013, most probably nearer to 948) in his Chronicle 131, 39-40. ${ }^{111}$ In his description, the ceremony is dated to the day of Pentecost, with no date according to the Julian calendar and no mention of any saints. The date 26 May has been determined by modern scholars as the date of Pentecost for the corresponding year. Most probably, the ceremony performed in St Sophia on Pentecost had no connexion to the commemoration day of either Gregory the Illuminator or of Sergius and Bacchus. Constantine Porphyrogenete, in his Life of Basil, 18, also describes the feast on this day as Pentecost, and mentions no other feasts. ${ }^{112}$

\subsection{Gregory the Illuminator and Isaac the Parthian as the Saints of the Macedonian Dynasty}

\subsubsection{Isaac the Parthian in Photius' Cult of St Gregory the Illuminator}

The cult of St Gregory the Illuminator promoted by Photius presumed a reference to some "prophecy." In his Life of Ignatius, Nicetas Paphlagon describes a complicated intrigue allegedly conducted by Photius after his involuntary retirement in 867. It was at this point that Photius began the work that paved the way for the official acknowledgment of Basil's descent from the Armenian Arshakids, and his account of the intrigue concludes with a prophecy about Basil's reign. The most interesting aspect here (and the aspect most neglected by modern historians) is the content of this prophecy. Nicetas Paphlagon does not go in detail, saying only that Basil was "prophesied" to be

(110) Vera Zemskova drew my attention to this coincidence of the dates.

(111) Symeon Logothetos, 252-253. I share the view of the editor and other scholars who do not identify this Symeon Logothetos with Symeon Metaphrastes. See, for details, the editor's "Prolegomena," ibid., p. $4^{*}-8^{*}$.

(112) BekKer, Theophanes Continuatus..., 239. 
"the most fortunate and the most long-living among all the emperors forever," and noting that the manuscript containing both the genealogy and the prophecy was full of such lies that everybody would roar with laughter when they heard about it. ${ }^{113}$

The most precise among the Byzantine authors is Constantine Porphyrogenete in his Life of Basil, 19. In describing Basil's coronation as co-emperor on 26 May 866, he wrote: "And then was accomplished a prediction and a prophecy (given) three hundred and fifty years before by Isaac, the most able seer among the priests and the monks, who was himself of the Arshakid descent, who has been taught by the vision that after the period of such number of years somebody from the descendants of Arshak will raise the sceptres of the Roman Empire."114 It is evident that Constantine means the well-known Vision of Sahak Part'ev (Isaac the Parthian; BHO 547), but from a specific Byzantine recension that was distinct from the literal Greek translation of the Vision which is preserved among the undated texts of the anti-Armenian polemics. ${ }^{115}$ The most obvious distinction is that both the Armenian original and its known Greek version deal with Armenia only and by no means with the Roman Empire, while the Vision in Constantine's recension concentrates exclusively on Byzantium. ${ }^{116}$

The Vision of Sahak in Armenian is known in a separate recension and it also appears within the text of the late fifth-century History of Lazar P'arpec' $i .{ }^{117}$ The text is the same in both cases. Its Armenian or-

(113) Nicetas Paphlagon, The Life of Ignatius, PG 105, 568 A: (Photius) ...ồ

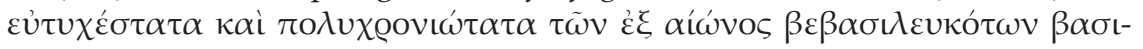

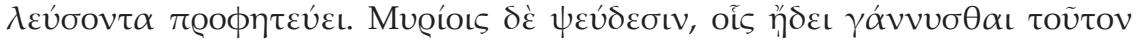

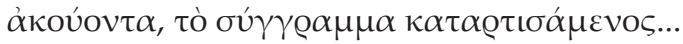

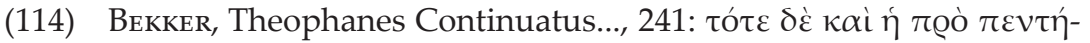

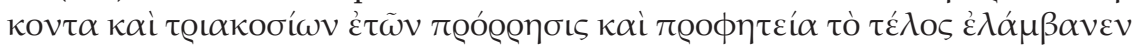

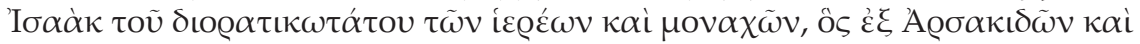

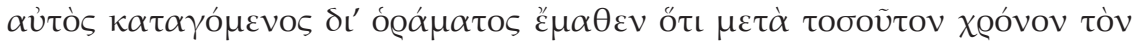

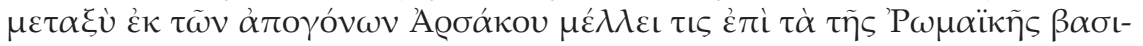

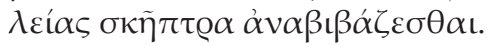

(115) G. GaritTe, La Vision de S. Sahac en grec, Mus 71 (1958) 255-278.

(116) The number 350 is retained from the original Armenian text although it makes no sense here: it refers to $516(=866-350)$ whereas Sahak Part'ev died ca 439.

(117) Text of the vision: Ququup Tupuligh, 60-75. The English translation by R. W. Thomson, The History of Łazar P'arpec'i (Atlanta, GA, 1991) is unavailable to me. A Latin translation of the Vision is provided by GARITTE, La 
igin is now considered as certain although its specific attribution to Lazar P'arpec' $\mathrm{i}$ is still in some dispute. In any case, the Vision is an early Armenian text. Its first mention in Greek appears in the list of the

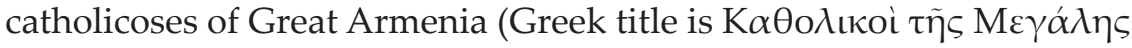

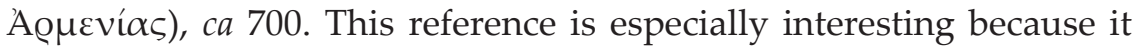
summarises the account of the situation when St Sahak tells of his vision. This account is known in Armenian in the text of Lazar $P^{\prime} \operatorname{arpec}^{\prime} i$, where it prefaces the Vision of St Sahak but is not part of the text of the Vision itself. The text of Lazar seems not to have been translated into Greek, although the context surrounding the occurrence of the Vision was certainly known in Byzantium, at least through this list of catholicoses. This situation bears a striking similarity to that of Photius between his two patriarchates, when he was composing (or, at least, adapting) the genealogy of Basil the Macedonian from the Arshakids.

Catholicos St Sahak was deposed because of intrigues among the Armenian princes. His three successors were not very successful, and the Armenian princes eventually repented and asked St Sahak to return to his see. He refused (leaving the position to St Mesrop Maštoc ${ }^{\prime}$ instead) and explained his actions by referring to the vision that he had received after having been deposed (§§ 13-24). ${ }^{118}$ Such a story would certainly have been near to Photius' heart after 867 .

Nicetas Paphlagon states that the Arshakid genealogy of Basil the Macedonian that was composed by Photius also contained some prophetic element. We know also, from Constantine Porphyrogenete, that this prophetic element went back to the Vision of St Sahak. We might thus reasonably recover other elements of this prophecy by comparing the contents of the Vision of St Sahak with the realities of the reign of Basil I.

The prophecy of Sahak focused on two figures, not only the king but also the patriarch. In this prophecy, the patriarch who will appear with the future Arshakid ruler will himself be a descendant of St Gregory the Illuminator and thus he, too, will be of Arshakid descent. Both

Vision de S. Sahac... A French translation of the whole text by Samuël Ghésarian is published in V. Langlors (éd.), Collection des historiens anciens et modernes de l'Arménie. T. 2 (Paris, 1869). Unfortunately, I had no access to the separate recension of the Vision, but it is reported to be almost identical to that of Łazar P'arpec'i.

(118) G. Garitte, La Narratio de rebus Armeniae. Édition critique et commentaire (Louvain, 1952) (CSCO, 132; Subs, 4) 403-404 (Greek text), 407-408 (Georgian version). 
the Arshakid king and the Arshakid priest are the messianic figures of the eschatological revival of the relevant kingdom (Armenia in the Armenian original but Byzantium in the Byzantine recension of the late ninth century): there "...will rise a king from the lineage of the Arshakids, and the patriarchal see will be renewed by the offspring of Saint Gregory" (...junit puquinn juqqtn Up2ulqniliuig, l innnqh upnn hujpuultinnıptiuid h 2 unuıtint uppnje Aphqnph:). ${ }^{119}$ The part of the prophecy of Sahak which concerns the Arshakid patriarch is completely suppressed from Constantine Porphyrogenete's account and not without reason, as we will see below - but it is traceable in earlier sources relating to patriarch Stephen I (886-893).

Stephen was officially the youngest son of Basil I (born in November 867) but, most likely, was actually a son of Michael III (as was Stephen's older brother, Leo VI the Wise). Basil had Stephen castrated in his childhood in preparation for a Church career. He became a monk during Basil's reign and was ordained as a deacon by patriarch Photius (in fact, Photius may have participated in Basil's plan to prepare Stephen for patriarchate ${ }^{120}$ ). Shortly after Basil's death (29 August 886), Leo VI deposed Photius (formally this was a voluntary resignation) and sent him into exile to the monastery of Bordi in Armenia; he then made Stephen patriarch, probably on Christmas Eve of $886 .{ }^{121}$ Stephen was consecrated at age 19 .

Such a turn of events must taken Photius by surprise, although he had violated the canons himself in ordaining Stephen as a deacon long before the canonical age (which was set at 25 years of age, according to canon 14 of the Council in Trullo, 692). In his Nomocanon (title I, ch. 23), Photius repeated Novella 123 of Justinian (ch. I, 1), which established the minimal age for episcopacy as 30 years or, in some exceptional cases, 25 years. ${ }^{122}$ However, Basil's idea that the next patriarch must be his own son, thus an Arshakid and also a descendent of St Gregory the Illuminator, fit the prophecy of Sahak and was thus duly approved by Photius. Indeed, Leo the Wise's funeral oration for

(119) Zuqun Aupuligh, 71.

(120) This opinion is shared by Tougher, The Reign of Leo VI..., 83 (Stephen as a figure close to Photius and, thus, acceptable to the clergy as patriarch).

(121) See especially J. Grosdidier de Matons, Trois études sur Léon VI : I. L'homélie de Léon VI sur le sacre du patriarche Étienne, TM 5 (1973) 181206.

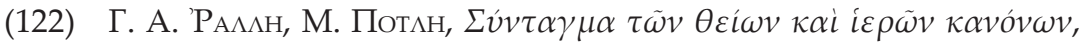
$\tau$. A' (Athens, 1852) 59-60. 
his father seems to confirm the idea that Photius agreed with Basil's desire to appoint his son as patriarch. Leo's funeral oration was delivered in September or October 886. Photius was still the patriarch at that time and was probably present when Leo delivered his speech (which expressed Leo's retroactive support of Photius in his earlier conflict with patriarch Ignatius). ${ }^{123}$

Leo praises Basil especially for establishing peace in the Church during the conflict between the two patriarchs, Photius and Ignatius. Leo then proceeds to connect this success in peacemaking to the dedication of his younger brother Stephen to the Church: Basil, he says, "...does not stop after having collected into the one (body) the divided Church but gave his child to the Church...," in a manner similar to that of Abraham. Leo's action, however, was even greater because Abraham acted according to the command of God, but Basil acted according to his own proper choice. "Thus, as if it was not he who gave something to God but as if he rather received the greatest (gifts) when acting as peacemaker for the Church, he confesses his gratitude presenting the fruit of the womb." 124 It is far from obvious why the dedication of his own child to the Church has any relation to peacemaking. At the time the speech was delivered, Stephen was not yet patriarch. Such an explanation of Basil's behaviour does not make sense unless we accept that this connexion between Stephen and the peace of the Church had something to do with the future. Indeed, if Stephen is the future Arshakid patriarch from the offspring of St Gregory the Illuminator, everything falls into place: Basil provided a temporary pacification of the Church through his intervention in the conflict between Photius and Ignatius, but after this he took measures toward establishing a definitive peace by dedicating his own son to the Church. Why was such an

(123) Leo's attitude toward Photius, as it is expressed in this homily, is analysed in the "Introduction" of the editors in A. Vogt, I. Hausherr, Oraison funèbre de Basile I par son fils Léon VI le Sage (Rome, 1932) (Orientalia Christiana, 26,1 = № 77) 18-23.

(124) Vogt, Hausherr, Oraison funèbre..., 64/65 (txt/French tr.) = Th. AnGelopoulou, Leonis VI Sapientis Imperatoris Byzantini Homiliae (Turnhout,

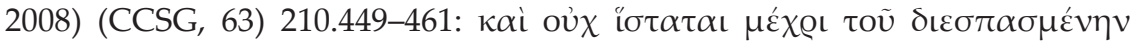

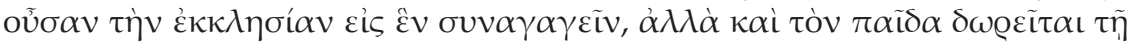

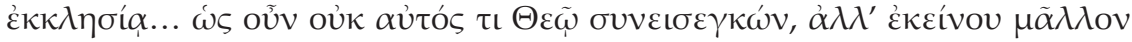

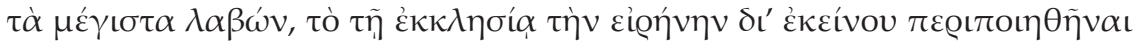

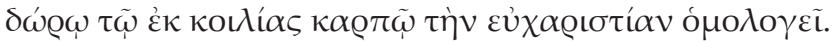


exotic measure considered effective? The only possible answer lies in the prophecy of St Sahak.

Another overlooked reference to the Vision of St Sahak is contained in an anonymous laudatory poem in honour of Basil I written, most probably, by Photius himself soon after his return to the patriarchal see in 877 (and if it is not by Photius himself, it certainly comes from his circle). The concluding part of the poem opens with the following lines (1. 198-199):

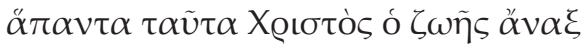

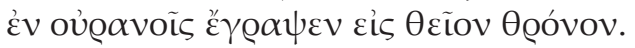

All the above Christ who is the king of life

Wrote in the heavens on the divine throne. ${ }^{125}$

To write something on the divine throne located in the heavens is not usual in Byzantine imagery. It would be tempting to understand these verses as containing an ellipsis, "Christ... (sitting) on the divine throne," but such a phrase would demand another preposition (غ่Tí instead of $\varepsilon i \zeta$; for $\varepsilon i \zeta$ in the corresponding meaning cf. Jn 8:6). In the Vision of St Sahak, the words quoted above about the future king from the Arshakids and the future patriarch from the offspring of St Gregory were written in golden letters on the parchment that was lying on the seat of the heavenly throne. ${ }^{126}$ It seems to me the most natural to understand the whole poem as a rhetorical composition on the motive of the renovation of the empire according to the Vision of St Sahak.

This brief review thus indicates that the prophecy of St Sahak was considered as pertaining both to Basil as well as to his son Stephen, who was also a constituent part of the so-called genealogy of Basil from the Arshakids. This, in turn, leads us to the conclusion that the Byzantine cult of St Gregory the Illuminator absorbed, under Basil, a new component: St Gregory became the forefather of the future patriarch, Stephen.

\subsubsection{St Gregory the Illuminator in the Cult of St Patriarch Stephen}

For Leo the Wise, it was certainly difficult to justify why Stephen could be allowed to become patriarch at age 19. Such an age of consecration was unprecedented even for ordinary bishops. Stephen's

(125) A. Markopoulos, An Anonymous Laudatory Poem in Honor of Basil I, DOP 46 (1992) 225-232, here 231.

(126) ใuqun Фunuligh, 71. 
reputation as the divinely appointed successor of Photius was an important precondition to the success of his appointment. In his homily on the consecration of Stephen, Leo does not limit himself to the usual phrases about the "divine choice" of the new patriarch "known by God before the conception," 127 but provides an allusion which is

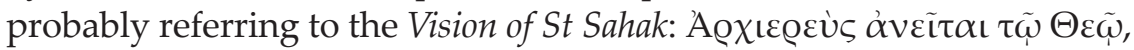

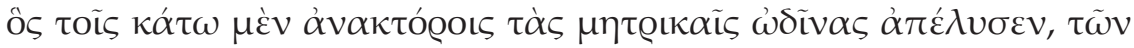

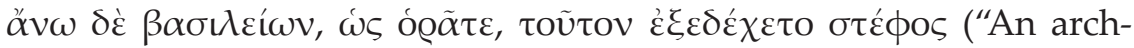
priest is promised to God - which resolved the maternal pains to the king's dwellings of below and received, as you see, this crown of the royal abodes of above"). ${ }^{128}$ The words "as you see" point to the current situation, that is, the consecration of Stephen as patriarch. This consecration does not presuppose any "crown," let alone a crown of an

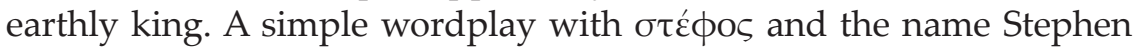
would not suffice to justify the mention of heavenly royal abodes (or "royal palaces") in a strict symmetry with the earthly ones. The royal descent of the new patriarch would justify such a metaphor but if Leo alludes to his descent from the saints belonging to the royal dynasty of the Arshakids it would make more sense. In the context of the Vision of St Sahak, such a metaphor would accentuate the descent of the patriarch from both royal and saintly stock. If this guess is true, Leo recalls the already well known prophecy of Stephen as the future patriarch according to the Macedonian reinterpretation of the Vision of St Sahakin trying to justify Stephen's uncanonical consecration at the age of 19.

Stephen's personal reputation at the time of his patriarchate was high. After his early death on 17 or 18 May 893, he was venerated as a saint. His relics were deposed in the monastery of St George the Syceote near the Blachernae. The day of his repose was a feast (17 or 18 May according to different recensions of the Synaxarium $\left.{ }^{129}\right)$. However, the main synaxis in his memory with a solemn procession from St Sophia to St George the Syceote monastery, where the Eucharistic liturgy was celebrated, was on 27 May. ${ }^{130}$ Thus, although the date of St Stephen's death on 17 or 18 May was a local feast in the monastery in which his relics were deposed, his main feast was celebrated on a different date,

(127) Angelopoulou, Leonis VISapientis..., 302.102 (cf. 300.43), 302.98-99.

(128) Ibid., 300.39-41.

(129) Synaxarium CP, cols. 689, 694. Cf. JANin 1969, 77-78.

(130) Synaxarium CP, col. 714. Mateos, Le Typicon de la Grande Église..., t. I. Le cycle des douze mois (Rome, 1962) (OCA, 165) 300/301 (txt/tr.). 
27 May, with a stational liturgy regulated by the Typicon of the Great Church. There must be a reason for the importance of the date 27 May.

This date makes sense within the cycle containing the commemoration of St Gregory the Illuminator, given both that St Gregory was considered as the forefather of Stephen and also that his cult included a commemoration of the prophecy of St Sahak about Stephen. A feast of St Stephen on this day is an indirect demonstration that the cycle including the commemoration of St Gregory the Illuminator on 26 to 28 May still existed in 893, and that the Vision of St Sahak was still present in the actual official ideology. Given that the saints whose relics were discovered in $\tau \dot{\alpha}$ K $\alpha \varrho \iota \alpha$ vov were enumerated in the Armenian account listing Gregory the Illuminator first, then Gaiane and Rhipsime, and finally Sergius and Bacchus, it is most likely that the day commemorating St Gregory was the first day of the cycle, 26 May, on the eve of the day of the commemoration of his alleged successor as patriarch, Stephen.

We see, however, that in the tenth century, the commemoration of St Gregory in May was suppressed - there is no trace in the Synaxarium or the Typicon. Moreover, we have seen in Constantine Porphyrogenete that the part of the prophecy of St Sahak concerning the Arshakid patriarch no longer fit the current situation and was probably forgotten. It is certain at least that the Vision of St Sahak ceased to be a document of actual Byzantine ideology and, in its Byzantine recension (where St Sahak prophesied about the Roman Empire, not about Armenia), it was completely forgotten. The Greek and Georgian versions available among the anti-Armenian polemical documents demonstrate its apprehension as a fulfilled prophecy about the interruption of priesthood in the Armenian Church.

Such changes occurred too rapidly to be a natural result of changing interpretations. Rather, one sees here the result of censorship due to a change in official ideology. The Arshakid genealogy of the Macedonian dynasty was still required, but now without its component relating to the patriarchate. The liturgical commemoration of St Stephen was nevertheless preserved, but not as a successor of St Gregory the Illuminator. The day of the main commemoration of St Stephen remained 27 May, in conformity with Baumstark's second law, ${ }^{131}$ but henceforth outside the liturgical cycle of St Gregory the Illuminator.

(131) "Das Gesetz der Erhaltung des Alten in liturgisch hochwertiger Zeit" ("...primitive conditions are maintained with greater tenacity in the more sacred seasons of the Liturgical Year"); see BAUMSTARK, Comparative Liturgy, 27-28. 
This cycle was suppressed, and the commemoration of Stephen on this day thus became apparently arbitrary, seemingly with no reason.

In addressing the sudden oblivion of the Vision of St Sahak and the suppression of the date of the discovery of the relics of St Gregory in May, we must pose two questions: who was interested in performing all this and by what means did they do so?

\subsubsection{The Cult of St Gregory the Illuminator under Patriarch Nicholas Mystikos}

The meaning of the May commemoration of St Gregory was connected (at least under Basil I) with the Vision of Sahak and, in turn, with the patriarchate of Stephen. His election at the age of 19 was an act unfriendly to Photius and his entourage. Photius' party regained the patriarchate after the death of Photius († 890/895, likely 893/894) in 901, in the person of his relative and disciple Nicholas Mystikos. He certainly did not accept the legitimization of Stephen's consecration by means of the prophecy of St Sahak. Thus, he was interested in the suppression of the corresponding May cult, as well as of the alleged prophecy of St Sahak concerning the patriarch of Constantinople. Such a reaction seems to be natural in the context of Photius' pre-886 ideology, now adapted to a different situation mutatis mutandis. The Arshakid genealogy is still preserved, but for the emperors only. No specific connexion between the patriarch of Constantinople and St Gregory the Illuminator was necessary, and thus there was no need to invoke the Vision of St Sahak. Nicholas Mystikos had neither the competence nor the need to abrogate the commemoration of patriarch Stephen, but it was necessary to him to break any association of Stephen's commemoration day with St Gregory and the prophecy of St Sahak.

Thus, the date of the suppression of the May commemoration of St Gregory and his companions is, most likely, in 901 or shortly thereafter, during the first patriarchate of Nicholas Mystikos (901-907). The means of the suppression will be dealt with in greater detail.

It was relatively easy to suppress the commemoration of St Gregory the Illuminator in May because the main day of his commemoration was 30 September (an ancient feast of Armenian origin, as discussed below). The commemoration in May was an additional one and related to the discovery of the relics. It was suppressed together with the memory of the discovery itself, and this is why we have no account of this discovery in Greek. Forgetting the discovery of the relics was the price to pay for the suppression of St Gregory's feast in May. 


\subsubsection{An Alternative to the Vision of St Sahak: the Apocalypse of Andrew the Salos}

The elimination of the Vision of St Sahak, because it could not be accomplished simply by decree, was a more difficult task. The only way to accomplish the fast and effective elimination of an ideological document was by issuing an appropriate competing document. As Michel van Esbroeck put it, "[r]ien n'élimine mieux un document que la création d'un parallèle destiné à le remplacer." 132

The document aiming to supersede the Vision of St Sahak had to be, of course, an apocalypse, that is, a document of the same genre as the original Vision. More precisely, it must be a piece of Reichseschatologie. ${ }^{133}$ There is only one such document which enjoyed an enormous popularity during the tenth century: the Apocalypse of Andrew the Salos (see above, 1.8.2, on the date of this apocalypse and the composite nature of the known recension of the Life of Andrew the Salos). Regardless of the exact date of this apocalypse (possibly the late seventh or the eighth century), it was (re)actualised in the tenth century when it was included in the Life of Andrew.

Incorporation into a hagiographic novel is a testament to widespread popularity. Properly speaking, only an already popular saint can become the main character of a hagiographical novel, ${ }^{134}$ and so the

(132) M. van Esbroeck, La Lettre sur le Dimanche, descendue du ciel, $A B$ 107 (1989) 267-284, here 283.

(133) Cf. G. Podskalsky, Byzantinische Reichseschatologie. Die Periodisierung der Weltgeschichte in den vier Grossreichen (Daniel 2 und 7) und dem Tausendjährigen Friedensreiche (Apok. 20). Eine motivgeschichtliche Untersuchung (München, 1972) (Münchener Universitäts-Schriften. Reiche der philosophischen Fakultät, 9).

(134) Everything said by Delehaye concerning the origin of the Passions épiques [especially in H. Delehaye, Les passions des martyrs et les genres littéraires (Bruxelles, $\left.\left.{ }^{2} 1966\right)(\mathrm{SH}, 13 \mathrm{~B})\right]$ is applicable to the hagiographic novels which are a particular case of the "epic" hagiography: the cult of a saint precedes the creation of his Life. However, the way in which the "anthological" hagiographic novel of the tenth century was created is more complicated: it presupposed an agglomeration of sources of varying nature (not only hagiographical) but, among others, some earlier hagiographic source(s) on the principal heroes (e. g., seventh-century recensions of the Barlaam and Ioasaph for the tenth-century Byzantine novel) or their prototypes (e.g., early Macedonian Gregory of Agrigent for tenth-century Gregentius of Taphar). The sources of other great tenth-century "anthological" novels (Life of Theodore of Edessa, Life of Basil the $\mathrm{New}$ ) have not been studied systematically, but the existence of a pre-existing 
rise in popularity of St Andrew the Salos, testified by the creation of his tenth-century Life, presupposes a noticeable increase in the popularity of his cult even earlier. This fact corresponds to the early tenth century as the date of the (re)appearance of the Apocalypse of Andrew the Salos as a self-standing work, a period that corresponds to the patriarchate of Nicholas Mystikos.

Unlike the Vision of St Sahak, the Apocalypse of Andrew the Salos is a traditional Byzantine historical apocalypse of the epoch opened by the Arabic expansion in the seventh century, fashioned after the "canons" established by the late seventh-century pseudo-Methodius of Patara. Thus, unlike the Vision of St Sahak, it was easily compatible with the Byzantine mentality. However, because the Apocalypse of Andrew the Salos seems so ordinary within the context of Byzantine tradition, it is difficult to discover anything in its contents that might provide specific reasons for choosing it as a counterweight to the Vision of St Sahak. One can reasonably suppose that, in the early tenth century, there were dozens of similar texts available. Their familiar Byzantine appearance was a necessary but insufficient condition to be chosen for replacing the authority of St Sahak. The real mechanism of replacement was to be effectuated within the cultic realm, that is, on the same level where the Vision of St Sahak had been planted in the Byzantine official ideology in the first place.

Here, our first interest lies in the hagiographical coordinates ${ }^{135}$ of the cult of St Andrew the Salos, that is, the place of its cult and the date in the calendar. The place of the early tenth-century cult of St Andrew is difficult to define ${ }^{136}$ but the earliest date of his liturgical commemora-

literary "core" in these cases seems more than likely. The case of the Life of Basil the New is similar to our case of the Life of St Andrew the Salos in the respect that its pre-existing "core" included an apocalypse (although not of the kind of Reichseschatologie but about the heavenly toll-houses). See Lourié, The Tenth Century: From roman hagiographique to roman anthologique, with further bibliography.

(135) On this notion, see H. Delehaye, Cinq leçons sur la méthode hagiographique (Bruxelles, 1934) (SH, 21), ch. 1.

(136) The place where St Andrew reveals his apocalypse to his disciple Epiphanius is indicated as the home of the latter, which is an unknown place. For the places of the veneration of St Andrew the Salos in late Byzantine Constantinople, see G. P. Majeska, Russian Travelers to Constantinople in the Fourteenth and Fifteenth Centuries (Washington, DC, 1984) (DOS, 19), esp. 315-316 and 383. Majeska assumes that the two St Andrew the Salos monasteries mentioned in Russian sources are not identical and that the mention of the relics of 
tion, which is the date of his death according to the Life, is 28 May. This date had to be retained by the hagiographer from the existing St Andrew cult. St Andrew, known in the early tenth century, at least, as the recipient of an apocalypse, was commemorated on 28 May. This date became the hagiographical coordinate of time for the cult approving a new historical apocalypse. Its proximity to the main commemoration day of patriarch Stephen, 27 May, and its belonging to the period of the earlier liturgical cycle from 26 to 28 May could hardly have been fortuitous.

After 893, the earlier cycle commemorating the discovery of the relics of Sergius and Bacchus, Gregory the Illuminator, and Gaiane and Rhipsime contained a commemoration of patriarch Stephen on 27 May. Initially, this commemoration was aimed only at proclaiming Stephen as the successor of St Gregory the Illuminator, as prophesied in the Vision of St Sahak. Patriarch Nicholas Mystikos, in removing both the commemoration of St Gregory on this day and the commemoration of Gaiane and Rhipsime on the next day, 28 May, was attempting to eliminate any connexion between patriarch Stephen and the Vision of St Sahak. Thus, the commemoration of St Andrew as the recipient of a genuine Byzantine historical apocalypse is suitably placed on the next day after the commemoration of patriarch Stephen. The earlier cycle covering the three days from 26 to 28 May was transformed into the three self-standing commemoration days of Sergius and Bacchus, Stephen, and Andrew the Salos. A connexion between Stephen and Andrew would have persisted until the memory of the earlier cycle had died out completely. The Synaxarium variants of the date of the commemoration of Sergius and Bacchus (from 26 to 28 May) demonstrate that the earlier cycle was reconsidered as dedicated to these martyrs exclusively. Such a three-day cycle of Sergius and Bacchus would not prevent the commemoration of other saints on the same days.

Taking into account St Andrew the Salos' commemoration date on 28 May, we have to accept that his cult approving his apocalypse was introduced (or, at least, reinforced) under Nicholas Mystikos as a replacement for the specific recension of the cult of St Gregory the Illu-

St Andrew in a late Russian recension of one of them is an interpolation with no historical value (taking into account that, according to the Life of St Andrew, his body was taken into heaven in the same manner as the body of the Theotokos). I would prefer to wait for a proper study of this interpolation and its possible source but, at any rate, the cult of St Andrew in Constantinople is too complicated a matter to be reviewed here. 
minator, which was connected to the cult of patriarch Stephen through the Vision of St Sahak. With the new cult of St Andrew, Nicholas Mystikos managed to break the link between Stephen and Gregory the Illuminator and to stop the circulation of the Byzantine recension of the Vision of St Sahak.

This state of affairs concerning the cult of St Andrew the Salos, established in the first patriarchate of Nicholas Mystikos, was altered by the establishment of a new feast of Pokrov but then restored in his second patriarchate (912-925) and preserved in the late Byzantine and post-Byzantine tradition until the nineteenth century. The Life of Andrew the Salos written later in the tenth century "canonised" this form of his cult with his commemoration date on 28 May.

The circulation of the Vision of St Sahak after 901 had thus been halted, but we will see that its impact was still traceable.

\subsection{The Veneration of "Pokrov" before the Feast of Pokrov}

\subsubsection{Photius, 860: the Discovery of "Pokrov"}

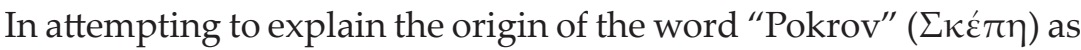
it is applied to the feast of the Theotokos, it became standard practice to quote the Akathistos: $\chi \alpha$ í $\lambda \eta \varsigma$ - "Hail, O Shelter [Pokrov] of the World, wider than the cloud[s]!" (oikos 6). This sixth-century text, however, has only a remote relation-

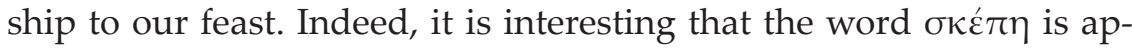
plied here to the Theotokos and that from the seventh century on, the corresponding hymn has been the central element of the most solemn festivity in the Blachernae Church (Saturday of Akathistos). However, the "Pokrov" in this text has no relation to any specific garment worn by the Theotokos. It is, rather, applied to the Theotokos herself.

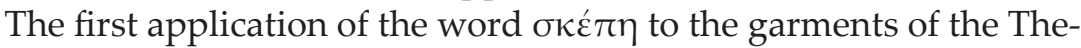
otokos is to be found in the Homilia secunda de oppugnatione barbarorum (= homily IV) of patriarch Photius, delivered on 4 August 860 almost immediately after repelling the Russian attack on Constantinople (end of July; the attack began on 18 June). ${ }^{137}$ The patriarch caused

(137) For the date, see J. Wortley, The Date of Photius' Fourth Homily, Byzantinoslavica 31 (1970) 50-53, supported, e.g., by C. Zuckerman, Deux étapes de la formation de l'ancien état russe, in: M. Kazanski, A. Nersessian, C. Zuckerman (éds.), Les centres proto-urbains russes entre Scandinavie, Byzance et Orient. Actes du Colloque International tenu au Collège de France en octobre 1997 (Paris, 2000) (Réalités byzantines, 7) 95-120. For an English translation and 
the wrecking of the entire Russian fleet by immersing the Robe of the Theotokos into the sea near the Blachernae Church. It appears that on this occasion, for the first time since the middle or late fifth century, the soros where the Robe had been preserved was opened. ${ }^{138}$

When Photius, in his homily after the victory over the Russians,

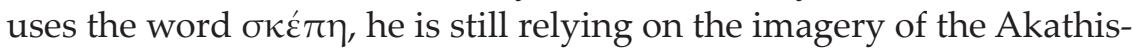
tos. Nevertheless, he makes an important shift in meaning. In speak-

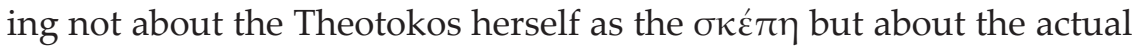

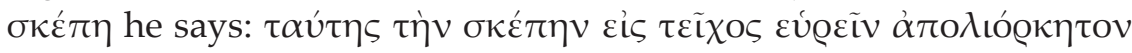
("...to find her [Theotokos'] shelter as a bulwark unassailable"). The mention of "bulwark" here is another reference to the Akathistos:

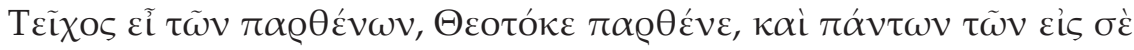
$\pi \varrho 0 \sigma \phi \varepsilon v \gamma o ́ v \tau \omega \nu$ - "A bulwark art Thou to virgins and to all that flee unto Thee" (oikos 10), but he introduces a new entity: a "shelter" of the Theotokos which is different from the Theotokos herself.

In the following lines, Photius focuses on the garment of the Theoto$\operatorname{kos}(\pi \varepsilon \mathrm{\iota} \beta \mathrm{o} \lambda \eta \dot{)})$ precisely in the function of a shelter, although at this point without an explicit identification: $\tilde{\eta} \varsigma$ [sc., of the Theotokos] $\kappa \alpha i$

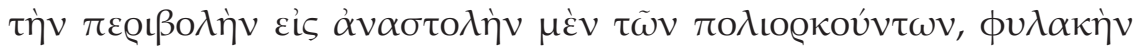

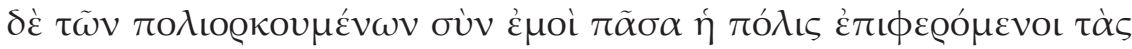

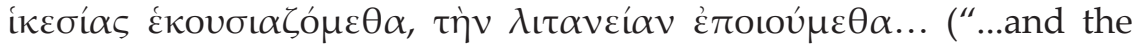
whole city together with me carrying over her garment as the repellent for those assaulting but the custody of those assaulted, we offer freely supplications and we serve the litany..."). ${ }^{139}$ However, near the end of the homily the identification between the garment of the Theotokos and her "shelter" becomes almost explicit: we were saved, Photius

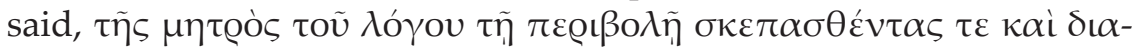
$\sigma \eta \mu \alpha v \theta \varepsilon \dot{v} \tau \alpha \varsigma$ ("...by the garment of the Mother of the Logos sheltered and marked out"). ${ }^{140}$

In Photius, "Pokrov" is still not a technical word for the Robe (garment) of the Theotokos deposed in the Holy Soros of Blachernae. However, through its function as shelter, the Robe becomes "Pokrov."

a general historical setting of Photius' homilies, see C. Mango, The Homilies of Photius Patriarch of Constantinople, ca. 820 - ca. 891 (Cambridge, MA, 1958) (DOS, 3).

(138) On the veneration of the Robe of the Theotokos in the fifth century and the corresponding hagiographical legends, see LouRIÉ 2007.

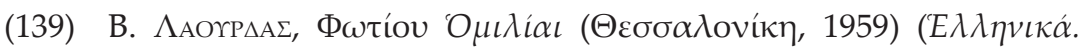

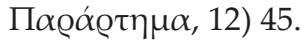

(140) Ibid., 51. 
It appears that this shift in meaning of the metaphor of $\sigma \kappa \varepsilon ́ \pi \eta$ used in the Akathistos was produced by Photius himself on the very day when his homily IV was delivered, Sunday, 4 August 860. In his first homily on the Russian attack (homily III), Photius also entrusted the City to the Mother of God, but without invoking this imagery at all. Instead, Photius asked the Theotokos to save the City by the means she

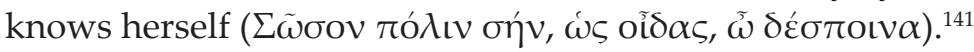

The panegyric of Theodore Syncellus to the Robe of the Theotokos (BHG 1058), which describes a siege of Constantinople interrupted by the miraculous intercession of the Theotokos acting through her Robe,

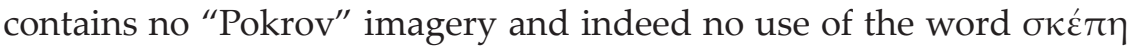
or its derivates at all. If it is true that this work is also dedicated to the Russian attack in $860,{ }^{142}$ it is another witness suggesting that the "Pok-

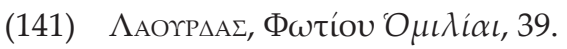

(142) For the text (the best but not a critical edition of the Greek original together with a Slavonic version and a Russian translation), see X. ПОПАРев, Старое свидетельство о Положении Ризы Богородицы во Влахернах в новом истолковании применительно к нашествию Русских на Византию в 860 г. [Ch. Loparev, An Old Testimony about the Deposition of the Robe of the Theotokos in Blachernae in a New Interpretation Applied to the Invasion of Byzantium by the Russians in 860], BB 2 (1895) 521-628. For the date and attribution to the events of 860 , see J. WortLeY, The Oration of Theodore Syncellus (BHG 1058) and the Siege of 860, Byzantine Studies / Études byzantines 4 (1977) 111-126 [repr.: IDEM, Studies on the Cult of Relics in Byzantium..., ch. XIII]. For a study and an English translation with commentary and with the complete earlier bibliography, see A. Cameron, The Virgin's Robe: An Episode in the History of Early Seventh-Century Constantinople, Byzantion 49 (1979) 42-56 (however, Cameron does not cite Wortley, following instead Vasil'evskij (1896) and Wenger (1955), and thus considering this text as related to the attack of the Avars in 619/620; Wortley returned to the viewpoint of Loparev which, since then, has been supported by Jugie (1944)). For the legend of Galbas and Candidus and its date and also about the origin of the feast of the Robe on 2 July, see Lourié 2007. The feast of the Theotokos established by the anonymous patriarch who is the central figure of Theodore Syncellus' panegyric is by no means that of 2 July. This date is too early if the events took place in 860 because the attack was repelled in the last days of July (Loparev was still unaware of the chronology of the Russian attack, now precisely established). If the events took place in $619 / 620$, this date is nevertheless unacceptable because the feast of 2 July has Palestinian origins (where it was the feast of the Ark of the Covenant in Cariathiarim) and was accepted in Constantinople as the common feast of the Robe and Juvenal of Jerusalem in the epoch of Zeno after the proclamation of the Henotikon (482); its hagiographical legend is that of Galbas and Candidus (BHG 1058a), which suppressed the earlier legend 
rov" imagery in Photius' homily IV was his personal invention and by no means commonplace.

After the time that Photius delivered his homily, a cult of "Pokrov"

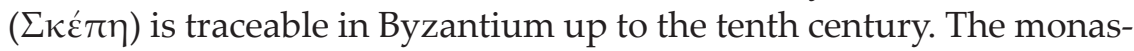
tery where Photius lived after his deposition in 867 was called $\Sigma \kappa \varepsilon ́ \pi \eta$. Pseudo-Symeon specifies that it is here where Photius composed the genealogy of Basil I from king Trdat. ${ }^{143}$ This monastery was located near Constantinople. ${ }^{144} \mathrm{~A}$ direct link between the dedication of the monastery and the wording of homily IV of Photius would not have been overlooked.

Janin supposed, although tentatively, that this is the monastery of $\Sigma \kappa \varepsilon ́ \pi \eta$ in which St Euphrosynia the Younger (ca 854-921/923) resided when she returned to Constantinople $c a 903 .{ }^{145}$ Janin hesitated in his identification because St Euphrosynia's monastery would have been for women, and thus would not have been suitable for Photius. It is possible, however, that the monastery changed its destination before

known through the Historia Euthymiaca. Theodore Syncellus clearly states that the feast whose origins he explains was established as a completely new one. No date of this feast is preserved within the text or its title (this means that the preserved manuscript tradition of the panegyric has no connexion to the liturgy) - probably because the feast had lost its importance or fallen into oblivion. It is probable that the corresponding feast is the synaxis of the The-

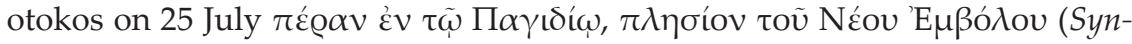
axarium CP, col. 844; cf. JANIN 1969, 208). Its date fits perfectly the chronology of the Russian attack of 860 (it is very possible that it was repelled on 25 July), although its place (near the New Portico which may be, according to Janin, in modern Beșiktaș) is too remote from Blachernae; however, this place of the synaxis according to the later tenth-century sources (the Synaxarium and the Typicon of the Great Church) may originally have been a secondary one but the only location that preserved an old commemoration.

(143) Nicetas Paphlagon, Life of Ignatius, PG 105, 640 B; BeKKer, Theophanes Continuatus..., 689.5ff. Both sources use an anti-Photian pamphlet contemporaneous to the events. See A. K[Azhdan], Symeon Magistros, Pseudo-, in: Kazhdan (ed.), The Oxford Dictionary of Byzantium, vol. 3, 1983.

(144) Janin 1969, 455.

(145) Ibid. The Life of Euphrosynia the Younger (BHG 627) by Nicephorus Callistus Xanthopoulos (early fourteenth century) is published by H. D[elehaye] in AASS Novembris III (1910) cols. 858-877; cf. his introduction

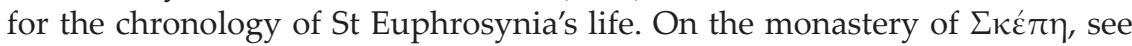
ch. 34 (874 B) and 47 (877 D: the miraculous healing of a nun of the monastery of $\Sigma \kappa \varepsilon ́ \pi \eta$ from the relics of St Euphrosynia). Thus, the monastery continued to exist for a while after 921/923. 
903. Be that as it may, the existence of one or even two monasteries of $\Sigma \kappa \varepsilon ́ \pi \eta$ demonstrates that some sort of cult of "Pokrov" existed. It is also remarkable that this cult was extinguished during the tenth century, when the monastery (or monasteries) disappeared.

\subsubsection{When "Pokrov" Becomes "Omophorion/Maphorion"}

When later Byzantine historians recalled the miracle of 860 , they replaced the word "garment" with the word "omophorion" or "maphorion." The earliest source is Symeon Logothetos (Chronicle, 131, 30 ), in the middle of the tenth century. Here, the garment of the Theotokos which Photius immersed in the sea is called "omophorion"

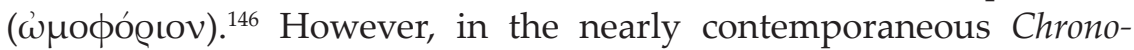
graphia of Pseudo-Symeon, the author uses the term "maphorion" ( $\mu \alpha-$ 申ó@ıov); ${ }^{147}$ his work dates from the late tenth century (his last entry is dated 963) and he uses the chronicle of Symeon Logothetos among his main sources. ${ }^{148}$ This change was easily possible because the word "omophorion" was often used instead of "maphorion" (a shawl-like vesture covering the head and shoulders) and not necessarily in the meaning of a bishop's pallium. ${ }^{149}$ Although the term might sometimes refer to a bishop's garment, generally it meant either a woman's cape and tippet or a monastic cape. ${ }^{150}$ Thus, the use of "maphorion" instead of "omophorion" may have been meant to clarify that the part of the Theotokos' garment used by Photius was, in fact, different from the distinctive bishop's pallium.

In any case, both "maphorion" and "omophorion" contradict the first person account of Photius, who used the word $\pi \varepsilon \mathrm{\iota} \beta \circ \lambda \eta$ which is not very suitable to describe a headdress. Nevertheless, even in Photius' lifetime, the word $\mu \alpha \phi$ ópıov became the usual term to indicate the Robe of the Theotokos in Blachernae (instead of the previous "in-

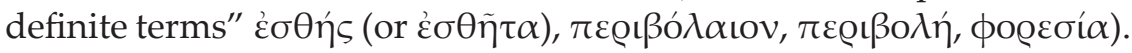
Wortley points to Joseph Hymnographer, the author of the liturgical canon for the feast of the Robe in Blachernae on 2 July, as the earliest

(146) Symeon Logothetos, 247.270.

(147) BeкKer, Theophanes Continuatus..., 674.22.

(148) A. K[azhdan], Symeon Magistros, Pseudo-.

(149) G. W. H. Lampe, A Patristic Greek Lexicon (Oxford, 1961) 1556.

(150) Ibid., 834. 
witness of this tradition. ${ }^{151}$ Indeed, in his canon to the Robe (most of-

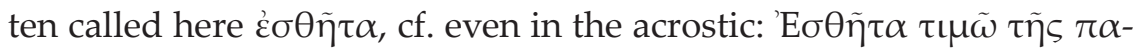

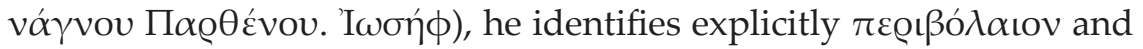

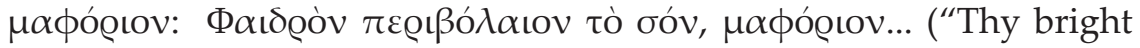
dress, maphorion..."). ${ }^{152}$

It is also important that Joseph elaborates on Photius' imagery of

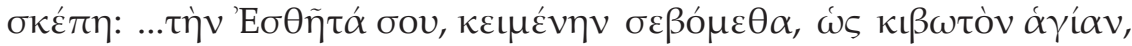

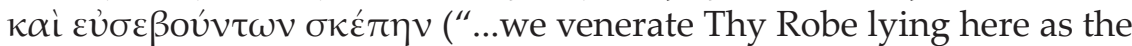
holy arc and the shelter (Pokrov) of the pious ones"). ${ }^{153}$ The service for 2 July as a whole is oversaturated with this "Pokrov" imagery, as Lathoud has pointed out, ${ }^{154}$ but there is no possibility of dating this hymnography. Even the date of the canon of Joseph is somewhat problematic due to the imprecise chronology of his life, ${ }^{155}$ but a post- 867 date is commonly accepted (this is when Joseph returned from exile after the deposition of Photius and even became his close collaborator during Photius' second patriarchate ${ }^{156}$ ).

(151) WortLey 2005, 185. The canon of Joseph on the Robe of the Theotokos is published in PG 105, 1004B-1009C; I will quote all Greek liturgical texts ac-

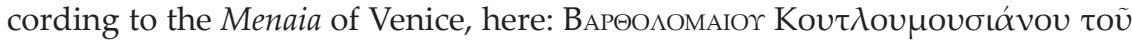

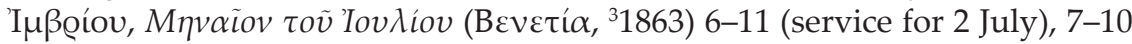
(canon).

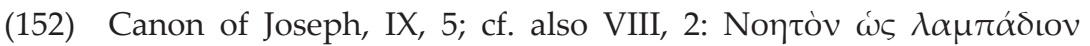

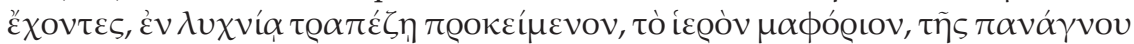

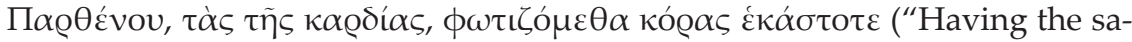
cred maphorion of the all-pure Virgin as an intellectual luminary staying on the candlestick of the table $<$ sc., altar $>$ we enlighten the pupils of the heart every time").

(153) Canon of Joseph, VII, 2; the same identification of the Robe with the maphorion in III, 3.

(154) I counted seven entries outside the canon of Joseph. Cf., for a review, D. Lathoud, Le thème iconographique du « Pokrov » de la Vierge, in: L'art byzantin chez les slaves. Recueil dédié à la mémoire de Th. Uspenskij. Deuxième recueil (Paris, 1932) (Orient et Byzance, 5) 302-314, here 302-303. Lathoud was the first who situated the service on 2 July in connexion to the Pokrov.

(155) In addition to the discussion of the exact date of Joseph's death during the second patriarchate of Photius (886 or 883), there is a problem of his (or some other Joseph's?) authorship of a canon to Theodora of Thessalonica, who died in 892. Cf. K[AZHDan], C[onomos], P[atterson] Š[evčEnKo], Joseph Hymnographer, 1074.

(156) Testified by both Lives of Joseph: Life by John the Deacon (BHG 945946), ch. 30 (PG 105, 968 D - 969 AB); Life by Theophanes the Monk (BHG 944), 
The same Joseph also wrote a liturgical canon for the feast of the Girdle of the Theotokos in the church of Chalkoprateia on 31 August; here it is the Girdle, rather than the Robe, that is the palladium of the City. ${ }^{157}$ Wortley thinks that this canon was written before 860 (thus, even before Joseph's exile in 858), when the Robe was considered as the second Marian relic after the Girdle. ${ }^{158}$ In this canon, the Girdle is

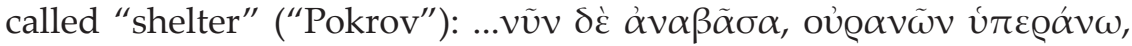

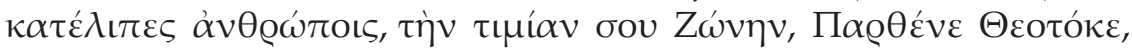

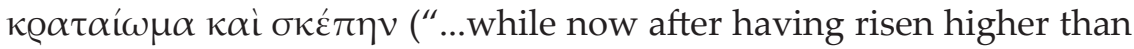
the Heavens Thou hast left to humankind Thy precise Girdle, o Virgin Theotokos, as strength and shelter"). ${ }^{159}$ If the "Pokrov" imagery applied to the Girdle is genuine (that is, not influenced by the cult of the Robe), it is the source of the same imagery applied to the Robe by Photius in 860. Its ultimate source remains unknown because the history of the cult of the Girdle of the Theotokos in Constantinople is far from being written. ${ }^{160}$

ch. 12 [А. ПаПадоПу ЛОс-Керамевс <A. Рapadopoulos-Kerameus>, Сборник греческих и латинских памятников, касающихся Фотия патриарха / Мопиmenta graeca et latina ad historiam Photii patriarchae pertinentia 2 (С.-Петербург, 1901) 10-11].

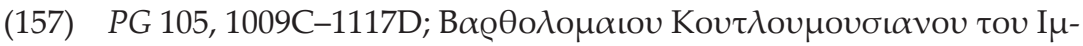

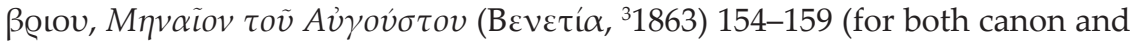
service as a whole).

(158) WortLey 2005, 184-185 and n. 32.

(159) Canon of Joseph, VII, 2; cf. I, 4: (Thy people, o Theotokos) ...úrò tìv

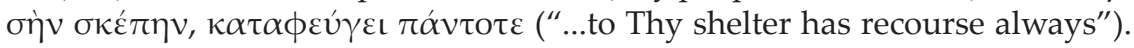
Other components of the service use the "Pokrov" imagery quite often but this is a secondary effect of the convergence with the service of 2 July. This convergence goes so far that both services share the same troparion apolytikon

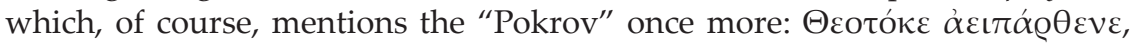

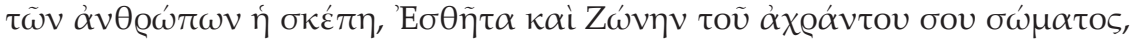

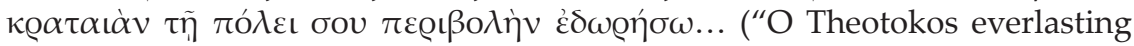
Virgin, the shelter of humankind, the Robe and the Girdle of Thy most pure body Thou hast given to Thy capital City as a covering [ $\pi \varepsilon \rho \iota \beta о \lambda \eta$, the term used by Photius in his homily IV for the Robe]...").

(160) Not even the hagiographical dossier of the feast is published in full (several unpublished homilies are enumerated in $B H G$ ). As an introduction to the dossier one can use WortLey 2005, which could be completed by the dossier of archbishop Sergij (Spasskij): Архиепископ Сергий (Спасский), Полный месяцеслов Востока [Complete Menologion of the East], t. III (Владимир, ${ }^{21901)}$ [reprint: Moscow, 1997] 346-348, who also published a Slavonic version of the 
Joseph Hymnographer is the earliest witness of the transformation of the Robe of the Theotokos into the maphorion. The date of this transformation is later than 860 - before this date documents do not mention "maphorion" at all. Joseph wrote his canon to the Robe after

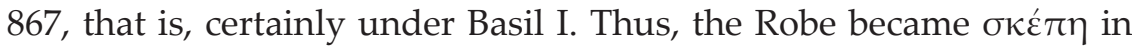
860 and "maphorion" sometime later, under Basil I. Around the same

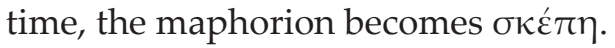

We must, therefore, study the mechanism by which this important transformation occurred.

\subsubsection{A Secondary "Pokrov" Cult: The Maphorion of St Theophano}

We have an important, yet indirect, witness of a late ninth-century maphorion cult. It is another cult in which a maphorion plays a prominent role: the cult of St Theophano, the first wife of Leo the Wise. It presupposed a veneration of the maphorion of Theophano herself as its major relic. It is also important that it is the only case of the veneration of the maphorion of any female saint, and thus it is specific to the time of Theophano's death (10 November of either 895 or 896).

Theophano finished her life in the Holy Soros Church in Blachernae, where she resided for a short time after having separated from her husband. According to the Life of Euthymius, her spiritual father and the future patriarch visited her for the last time in her abode in the Holy Soros. At that time, she transmitted to him, together with the precious liturgical vessels and their veils, her shawl. Euthymius'

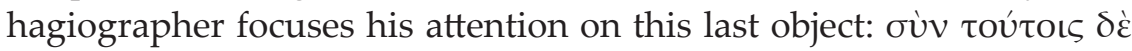

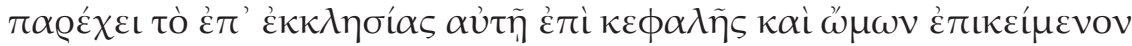

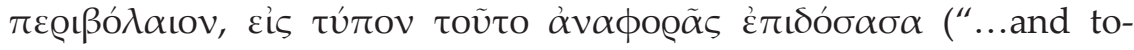
gether with these she hands over the covering, $\pi \varepsilon @ \iota \beta$ ó $\lambda \alpha \iota$ v, which she wore in the church on the head and the shoulders adding it as a

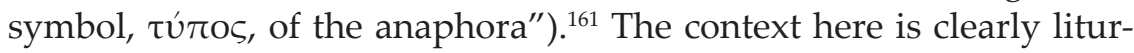
gical: $\alpha \dot{\alpha} \alpha \phi$ o@ $\alpha$ is mentioned as an addition to the liturgical vessels with their veils. Although the shawl is not the $\alpha v \alpha \phi o 0 \alpha$ (Eucharist) itself, it is, nevertheless, its symbol (typos). It is also important that the same scene contains an indirect but clear indication that Theophano is

entry on 31 August of one of the recensions of the Synaxarium of Constantinople which is lost in the Greek original: ibid., t. I (Владимир, ${ }^{21901)}$ [reprint: Moscow, 1997] 597.

(161) P. Karlin-Hayter, Vita Euthymii Patriarchae CP. Text, Translation, Introduction, and Commentary (Bruxelles, 1970) (Bibliothèque de Byzantion, 3) 45. 
a saint: Euthymius, himself a saint, asks her in the same manner as the

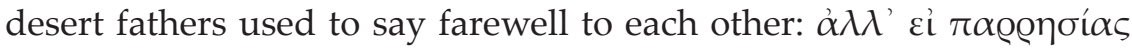

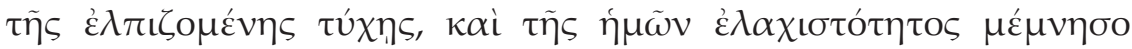
("...but if you achieve the hoped-for boldness, let you remember our most humble self"). ${ }^{162}$ Let us recall that the above scene took place in the Holy Soros Church, the epicentre of the cult of the maphorion of the Theotokos since the reign of Basil I.

A contemporary Life of Theophano (BHG 1794) reports miracles from her shawl, which is always called a $\mu \alpha$ фó was deposed in the Church of the Holy Apostles, where Theophano herself was buried. Chapter 25 describes a miraculous healing of a possessed woman. This woman met a man who was carrying Theophano's maphorion wrapped in a thin tissue. She started to disparage St Theophano. The man was unable to hold back his anger and he hit her on the head with the maphorion, whereupon the woman healed immediately. The man who was carrying the maphorion was heading for the father of the hagiographer himself, who, of course, was also healed with the maphorion. The maphorion is mentioned throughout this account, each time with epithets familiar for the maphorion of the

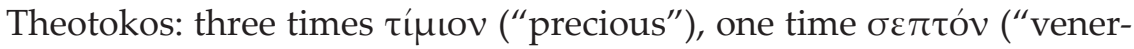
able"), and one time even $\theta \varepsilon \tilde{c}$ ov ("divine"). ${ }^{164}$

In another scene of healing (ch. 27-29), a paralysed boy sees in a vision the Theotokos visiting him hand-in-hand with Theophano. The Theotokos orders Theophano to heal the boy, but she declines. The Theotokos insists, however, and Theophano concedes. Here, Theophano is presented as a "deputy wonderworker" of the Theotokos. The Theoto-

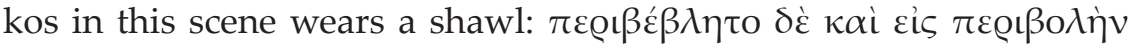

(162) Karlin-Hayter, Vita Euthymii..., 45.

(163) The Slavonic version of another Life of Theophano (see A. Kreinina, The Life of Theophano the Empress: the Slavonic Recension of an Unknown Byzantine Original, Scr 7-8.1 (2011-2012) 169-230), which is lost in Greek, has in the corresponding places $3 \mathrm{ak}$ tı $($ e.g., f. 83v), which is normally used to render

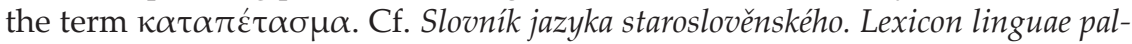
aeoslovenicae 1 (Praha, 1966) [reprint: C.-Петербург, 2006] 631. Thus, it is not

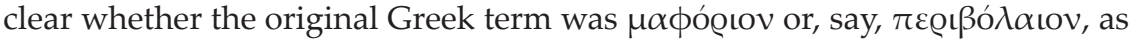
in the Life of Euthymius.

(164) E. Kurtz, Zwei griechische Texte über die hl. Theophano die Gemahlin Kaisers Leo VI., Mémoires de l'Académie Impériale de St. Pétersbourg, sér. VIII. T. III, 2 (1898) 17-18. 
$\mu \alpha \phi o @ i ́ v$ ("dressed with the dress of maphorion"). ${ }^{165}$ This episode makes clear the relationship between the two maphoria: one is a copy of the other.

The possibility of such a "secondary" maphorion cult reveals that the cult of the maphorion of the Theotokos deposed in the Holy Soros in Blachernae was already quite strong up to the beginning of the 890s (that is, to the last years of Theophano's life). Enough time had passed by this point - that is, after the cult had started under Basil I no earlier than 867 - to establish it securely.

Thus after only about twenty years or even less, the cult of the maphorion was extremely fashionable, even to the extent of producing a secondary relic, the maphorion of Theophano. But the case of the maphorion of Theophano remained a unique exception. Beginning in the middle of the tenth century, "maphorion" is one of the routine synonyms of "Robe," attracting no specific interest to its precise form. The only exception is the "Russian" feast of Pokrov and, to some extent, the Byzantine and Russian iconographical traditions that may have their roots in the Pokrov-related Byzantine iconography. ${ }^{166}$

(165) KurTz, Zwei griechische Texte..., 19-21, esp. 20.

(166) Here I avoid any discussion of the possible Byzantine roots of the earliest Russian iconography of the Pokrov which is often posed in connexion to the rite of the "Usual Miracle" in the Blachernae Church (this rite is to be dated not later than to the eleventh century). Sеe Н. П. Кондаков, Иконография Богоматери [N. P. Kondaкоv, The Iconography of the Theometer]. T. 2 (Петроград, 1915) 92-103; Lathoud, Le thème iconographique du « Pokrov »...; A. Grabar, Une source d'inspiration de l'iconographie byzantine tardive: les cérémonies du culte de la Vierge, Cahiers archéologiques 26 (1976) 152-162; В. Г. Пуцко, «Богородиця Десятинна» - міф чи історична реалія? [V. G. Putsкo, The "Theotokos of the Tithes Church": a Myth or a Historic Artefact?], Ruthenica 5 (2006) 162-169; B. V. Pentcheva, Icons and Power: The Mother of God in Byzantium (University Park, PA, 2006) 145-163, 236-242. My main reason for avoiding this discussion here is the fact that the two earliest iconographic traditions of the "Pokrov" contradict both the Life of Andrew the Salos and the Prolog Pokrov entry in an important detail: the maphorion of the Theotokos is not in her hands but in the hands of angelic figures above her head. It appears in this way in the Pokrov section of the Suzdal Golden Gates (1220s/1230s) and in the Galician Pokrov icon. The latter is now dated to the second half of the eleventh century or the early twelfth century according to the radiocarbon analysis of the icon panel: $\Lambda$. Г. ЧАЕновА, К вопросу атрибуции древних икон из собрания Национального Художественного музея Украины с помощью радиоугдеродного метода [L. G. ChLENova, Towards the attribution of the ancient icons from the collection of the National 
The vision of St Andrew the Salos in the Holy Soros and the establishment of the feast of Pokrov would presuppose such an interest in the fashion of the Virgin's Robe. Such an interest was extremely high ca 900, enhanced by the accompanying cult of St Theophano - a saint whose abode was the Holy Soros, whose main relic was her maphorion, and who became a "deputy healer" of the Theotokos.

\subsubsection{How "Pokrov" Becomes “Omophorion/Maphorion"}

After having answered when the "Robe" of the Theotokos became the "maphorion," we are now in a position to ask how this happened and then to be able to ask why.

The most natural explanation would be a change of the material artefact, as if there were two different relics, one the principal artefact and a different one overshadowed by the first; these two artefacts, during the reign of Basil I, would then have swapped places. At first glance, this hypothesis seems to be corroborated by some facts.

The earliest explicit mention of the "maphorion" of the Theotokos is contained in the Life of Theodore the Syceote, ch. 128, written by his disciple Georges the Syceote soon after the death of the saint in 613. Patriarch of Constantinople Thomas (607-610) presented the saint with a golden cross with relics embedded in the middle. Among the relics, there was the "hem of the shawl ( $\mu \alpha \phi$ ópıov) of the Most Holy Theotokos". Nothing is said about the place where the shawl itself was preserved. ${ }^{167}$

Wortley is sceptical about the possibility that the maphorion in this cross represents a relic independent of the two major Theotokian relics of Constantinople, her Robe in Blachernae and her Girdle in Chalko-

Art Museum of Ukraine with the radiocarbon method], Восточноевропейский археологический журнал [The East European Archaeological Journal] 8 (13) (2001) http://archaeology.kiev.ua/journal/061101/chlenova.htm (electronic journal) (for this reference I am grateful to Feofan Areskin). This fact means that the origins of the earliest Russian Pokrov iconography are even more unclear than is commonly thought.

(167) A.-J. Festugière, Vie de Théodore de Sykeôn. Vol. I (Bruxelles, 1970)

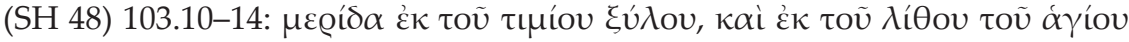

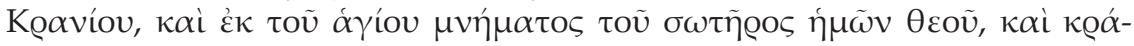

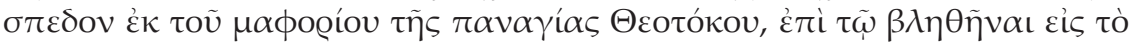

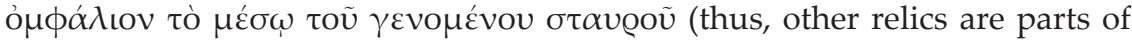
the True Cross, the stone of Golgotha, and the Holy Sepulchre). Cf. Wortley 2005, 180-181. 
prateia. Instead, he opts for two variants as the most probable: this maphorion is either from the the Robe itself or it is a deliberate fraud (resulting from the "promiscuous proliferation of relics"). ${ }^{168}$ In addition, Wortley discusses the possibility of the identity of this maphorion with some other similar relics mentioned under different names. He concludes that it is perhaps impossible to distinguish between the different fabrics attributed to the Theotokos in our sources. ${ }^{169}$ I would emphasise however that only seldom are such fabrics described in terms similar to those describing the maphorion. I know only two examples, apparently with no relation to Constantinople of the late ninth century. ${ }^{170}$ Therefore, the hypothesis that the "Robe" became the "maphorion" as a result of some change of the material object of the cult seems extremely unlikely.

Thus, without contradiction to the known facts we have to conclude that the garment of the Theotokos preserved in the Blachernae Church and used by Photius in 860 was simply reinterpreted as being a maphorion. This is our answer to the question how.

Possibly some earlier traditions about a maphorion-like relic of the Theotokos preserved in Constantinople played some role in this process of reinterpretation, possibly not. In any case, there was no such tradition concerning the garment preserved in Blachernae before its first evidence in the canon of Joseph Hymnographer. The difference in

(168) Wortley 2005, 180, 184.

(169) Ibid., 185-186.

(170) According to an early legend preserved within the Arabic Transitus AB 8 (CANT 175), empress Eudocia received a "turban" (عمامة; here a render-

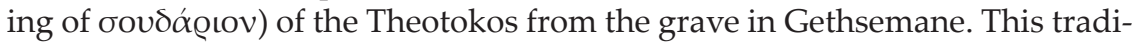
tion corresponds to the fact that the earliest legend of the vestment of the Theotokos in Constantinople (reported in the Historia Euthymiaca but dated to the 450s) presents it as a funerary garment (see LouRIÉ 2007; cf. ibid. on the parallel with the ligamentum, quo utebatur in capite of the Theotokos in the Jerusalem Sion basilica ca 570). A relic called "повоi of the Saint Theotokos" is reported by the Russian pilgrim Antony in 1200 as being placed in the Imperial palace: Х. М. Аопарев, Книга Паломник. Сказание мест Святых во Цареграде Антония Apхиепископа Новгородскаго в 1200 zодy [Kh. M. Loparev, The Pilgrim Book. A Narration on the Holy Places in Tsargrad by Antony Archbishop of Novgorod in 1200] (С.-Петербург, 1899) (Православный Палестинский Сборник, XVII, 3) 19. The word used by Antony has different meanings, including a woman's headdress like a shawl, but it can also mean "shroud"; cf. Croвap русского языка XI-XVII вв. [A Dictionary of the Russian Language of the EleventhSeveteenth Centuries] Вып. 15 (Москва, 1989) 166. 
terminology between this canon and Photius' 860 homily is especially revealing.

\subsubsection{The Bishop's "Maphorion" of St Gregory the Illuminator}

There must be some specific impetus for such a redefinition of existing terminology. Was there a specific conception of the term "maphorion" in Constantinople under Basil I? Before answering yes we must discuss a unique case in which the word "maphorion" is used in the sense of a bishop's omophorion. This is the so-called Escorial Life of St Gregory the Illuminator $(B H G 712 \mathrm{~g}=\mathbf{V g}) \cdot{ }^{171}$ Unlike other recensions of the Life of St Gregory (including those of the Armenian Agathangelos Aa, its Greek version $\mathbf{A g}$, and the metaphrastic reworking of the latter, BHG 713), this text describes in detail the rite of the consecration of St Gregory (ch. 145). Garitte noted the striking similarity of this text with the Byzantine rite of the consecration of a bishop according to the eighth-century Euchologion Barberini. ${ }^{172}$ After having completed the act of the laying on of hands with the prayer of consecration, the bishops put the omophorion on their newly-consecrated colleague with the triple acclamation "Worthy! Worthy! Worthy!" In the description of this standard procedure Vg calls the omophorion a "maphorion" (145.6). Given that the rite described here is quite similar to the known one from the Euchologion Barberini, we are sure that $\mu \alpha \phi$ ó the meaning "omophorion." This is a strange and short-lived terminological usage.

(171) Not reported in the dictionaries (cf. above, n. 143), the unique case for the whole database of the TLG (September 2010). Publication of the text according to the unique manuscript: G. GARITTE, Documents pour l'étude du livre d' Agathange (Rome, 1946) (Studi e Testi, 127) 23-116. For a more up-todate introduction to the complicated hagiographical dossier of St Gregory the Illuminator, see R. W. Thomson, Agathangelos, History of the Armenians. Translation and commentary (Albany, 1976) [contains a reprint of the 1909 criti-

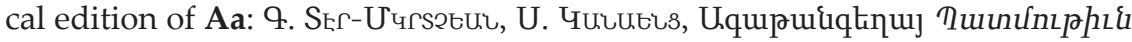

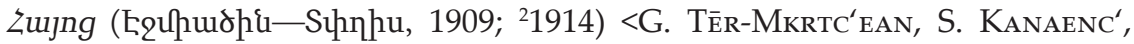
Agathangelos' History of Armenia (Etchmiadzin-Tiflis, 1909; ${ }^{21914)>}$ ] and К. С. Тер-Давтян, С. С. АревшАтян, Агатангелос, История Армении. Перевод с әревнеармянского, вступительная статья и комментарии (Ереван, 2004) [K. S. Ter-Davtjan, S. S. Arevšatjan, Agatangelos, The History of Armenia. Translation from Old Armenian, Introduction, and Commentaries (Yerevan, 2004)].

(172) GaRitte, Documents..., 132-134. 
Vg together with Vo (BHG 712c) go back to a lost early Armenian Life independent of the Armenian Agathangelos and representing the ideology of some circles more oriented toward imperial unity than to Armenian isolationism. ${ }^{173}$ The date of the Greek translation is unknown but may be estimated from the following considerations. The unique manuscript $\mathbf{V g}$ is dated to 1107. A very early date for the Greek translation, contemporaneous to Ag (sixth century), is considered by scholars as less likely than a later one. However, the Arabic recension Va (BHO 332) goes back to $\mathbf{V g}$ and is preserved in a tenth-century Sinai manuscript; the date of the translation itself is thus the ninth or the tenth century, which corresponds to the earliest layer of Christian literature in Arabic. The account of the consecration of St Gregory in $\mathbf{V a}$ is an exact translation of the corresponding passage of $\mathbf{V g} .{ }^{174}$ The only modification is the replacement of the term "maphorion" with the term "sticharion" (Byzantine analogue of "alb"). The corresponding term الاستخارية (al-istihāriyyat) is a slightly Arabised transliteration of

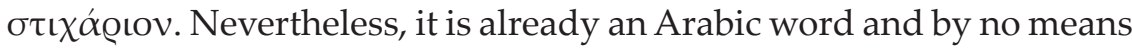
a slavish transliteration of an obscure foreign term. The Arabic translator thought that the piece of the bishop's garment he describes is indeed a sticharion. Needless to say, the mention of sticharion at this moment of the service is extremely inappropriate. It can be explained only as an unhelpful attempt to translate $\mu \alpha \dot{\phi} \phi o @ ı v$ in its usual sense of shawl.

This Arabic version shows us that our Greek text in its known form (in which the bishop's omophorion is called a "maphorion") was considered in the ninth and not later than the early tenth century within the influential monastic milieu of Sinai and Palestine ${ }^{175}$ as an important

(173) See GaritTe, Documents..., for $\mathbf{V g}$, and IDEM, La vie grecque inédite de saint Grégoire d'Arménie (ms. 4 d'Ochrida), AB 83 (1965) 257-290, for Vo (the so-called Ochrid Life known in the fragmentary ms of the tenth century covering the passion of the holy virgins). Thus, I would prefer to abstain from any guess about the plausibility of the use of the Byzantine rite of the consecration of a bishop in the corresponding Armenian milieu. The rite as described in the Euchologion Barberini is impossible to date precisely.

(174) Н. МАрР, Крещение армян, грузин, абхазов и аланов святым Григорием [N. MARR, The Baptism of the Armenians, the Georgians, the Abkhazians, and the Alanians by Saint Gregory], Записки Восточного отделения Императорского Русского Археологического общества [Notices of the Oriental Department of the Imperial Russian Archaeological Society] 16 (1905) 63-211, here 128.

(175) On this milieu, see S. H. Griffith, Arabic Christianity in the Monasteries of Ninth-Century Palestine (Ashgate, 1992) (Variorum Collected Studies Series, CS380). 
hagiographical source - worth translation, although its specific usage of the word "maphorion" was in this milieu incomprehensible.

Among Byzantine texts, there is one providing a distant parallel to the wording of $\mathbf{V g}$. This is the tenth-century hagiographical novel The Life of St Gregentios (1.50). Gregentios' mother sees a prophetic dream on the night when Gregentios was born: St Nicholas endows her son with many symbolic gifts mostly having ecclesiastical meaning, and,

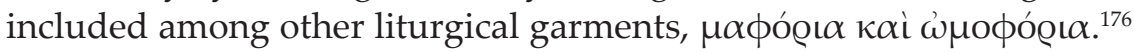
Given that there is no liturgical garment normally called $\mu \alpha \phi$ ó ıov, it is reasonable to conclude that we have here a pleonasm, $\mu \alpha \phi$ ó $\alpha \alpha$ being used in the sense of "omophoria" and $\omega \mu$ oфó́ $\alpha$ added as a more popular synonym.

Vg and, indirectly, Va demonstrate that the word $\mu \alpha$ фógıov was used as a synonym of the high $\omega \mu$ oóóotov in ordinary language (as it is in the Greek of $\mathbf{V g}$ ), but within a relatively small and strict hagiographical genre in the ninth or the early tenth century (or, of course, possibly even earlier). The Life of St Gregentios preserves a trace of this usage in a later time, in the tenth century, but now within the freer genre of the long hagiographical novel. After this, it disappears completely.

We have no data on the origin of such usage and we do not know the date of $\mathbf{V g}$. It is enough for us, however, to know the two following facts: (1) such a usage was actual (probably actualised) in the late ninth century, together with $\mathbf{V g}$, and (2) its actuality was connected with the actuality of the cult of St Gregory.

These two facts lead us to the time of patriarch Photius, but especially to the early Macedonian period. The bishop's "maphorion" as a substitute for the term "omophorion" was brought to Constantinople by Gregory the Illuminator together with his Vg and was forgotten in the tenth century, when the Macedonian dynasty became stable, and, correspondingly, its Armenian heavenly patrons lost their outstanding importance.

\subsubsection{Why "Pokrov" Becomes "Omophorion/Maphorion"}

Now we are able to trace the origins of the peculiar terminology applied to the omophorion of St Gregory the Illuminator. This omophorion plays an extremely important role in the Vision of Sahak. In

(176) A. Berger, Life and Works of Saint Gregentios, Archbishop of Taphar. Introduction, Critical Edition and Translation (Berlin-New York, 2006) (Millenium-Studien zu Kultur und Geschichte der ersten Jahrtausends n. Chr., 7) 190. 
this vision, the most important objects were indeed the omophorion of St Gregory and the orb (golden sphere) of the Arshakids. ${ }^{177}$ Sahak sees them on the silver plate placed on the heavenly altar table. Then, the angelus interprens explains that the omophorion means the sacerdotium from St Gregory and the golden globe means the regnum of the Arshakids. ${ }^{178}$ Such a context does not allow any other interpretation of the word used for "omophorion." The word used in the Vision of Sahak is quuhnpun (nap'ort), an early classical borrowing from Greek (a

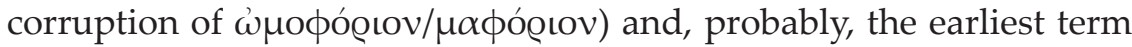
for the bishop's omophorion in classical Armenian (its synonyms are attested much later) ${ }^{179}$ However, fuuhnpun carries the whole spectrum of meanings of its Greek prototype, including "(woman's) shawl," etc. In the Greek literary translation it is rendered, notwithstanding the real meaning of the passage, as v́ $\phi \alpha \sigma \mu \alpha^{180}$ ("veil"), while the Georgian translation is correct in using the words that mean "(bishop's) omo-

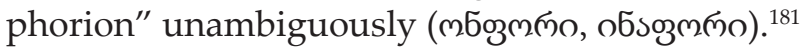

When Vg calls the bishop's omophorion "maphorion," it tries to match the semantics of nap'art in its Armenian prototype, ignoring the

(177) The orb was a rather common sign of imperial power. For its use by Basil I, see G. Moravcsiк, Sagen und Legenden über Basileios I, DOP 15 (1961) 61-126, 11 pl., here 80.

(178) huqup Tupultigh, 62, 71.

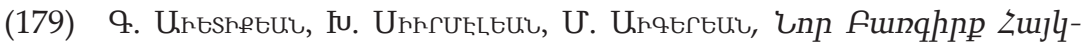

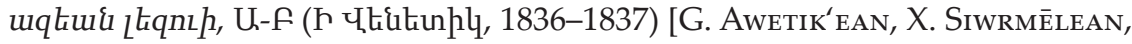
M. Awgerean, A New Lexicon of the Armenian Language, 2 vols. (Venice, 1836-1837)], s.v. Guuhnpun (II, 409 ; with a variant quufunnun) and tudhధnpni (I, 658; with variants tưuนnnnu, tưuuhnpun, all of them being closer to Greek

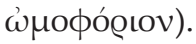

(180) Garitte, La Vision de S. Sahac en grec, 265, 273.

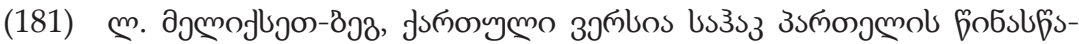
๓дjo̊yjmgðools [L. Melisket-Beg, The Georgian Version of the Prophecy of

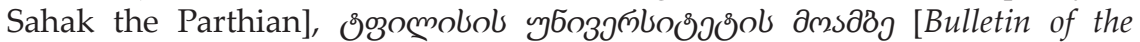
University of Tiflis] 2 (1922-1923) 200-221, here 208.16 and note 7; 213.23 and note 13 (two manuscript variants). This term is dicussed in $\Lambda$. МЕдИКСет-Беков, О грузинской версии апокрифического Видения Саака Парфянина о судьбе Армении [L. Meцiкseт-Bекоv, About the Georgian Version of the Apocryphal Vision of Sahak the Parthian Concerning the Destiny of Armenia], Известия Кавказского Историко-Археологического института / Bulletin de l'Institut Caucasienne [sic] d'Histoire et d'Archéologie 2 (1917-1925) 164-176, here 175. In the later Georgian usage the omophorion is normally called magुmळo/ мамоुмखо . 
fact that the Greek liturgical terminology is more specific and thus normally does not allow the use of the word "maphorion" in this sense.

As we have seen above, the role of the Vision of Sahak in early Macedonian ideology was not limited to the secular aspects of legitimising the dynasty. The part of the prophecy pertaining to the patriarch was actualised as well. It would be therefore only natural if the omophorion seen by St Sahak figures in the Macedonian imagery in at least some way. Thus, let us consider the following synchronism: the Vision of St Sahak becomes a basic document of the Macedonian ideology after 867 and preserves its status until about 901 (see above); the date of the transformation of the Theotokos' Robe into "maphorion" is also after 867 and before 883/886. Under Basil I, before the consecration of Stephen in 886, the omophorion in the Vision of St Sahak is still waiting for its owner, the future patriarch from the stock of St Gregory the Illuminator who is identified - in the Byzantine context - with the future patriarch Stephen.

When the garment of the Theotokos, the palladium of the City, was renamed "omophorion," it was an expression that the Theotokos had become the locum tenens of the eventual patriarch from the stock of the Arshakids. Until the omophorion of St Gregory finds its owner, the Theotokos herself, with her own omophorion, stands watch over her City.

Of course, after 893 and especially after 901 (under Nicholas Mystikos), this meaning of the omophorion of the Theotokos lost its actuality and subsequently fell into oblivion.

From this reconstruction of a short-lived ideological imagery we have to keep in mind two important facts: (1) the holy garment of the Theotokos became an "omophorion" under the strong influence of the cult of St Gregory the Illuminator; and (2) the imagery of "omophorion" was used, according to our reconstruction, as a compensation for the lack of legitimacy of the patriarch of Constantinople (Stephen).

\subsection{Conclusion to the Armeno-Byzantine Dossier}

Liturgical commemorations of St Andrew the Salos and Pokrov are adjacent to those of St Gregory the Illuminator and other saints of his entourage. This fact suggested an exploration of the hagiographical dossier of St Gregory the Illuminator in Byzantium in the second half of the ninth century.

The revival of the cult of St Gregory initially developed in the context of the Church politics of patriarch Photius and his attempts at reuniting the Armenian and the Byzantine Churches. The relics of St 
Gregory the Illuminator and Gaiane and Rhipsime were discovered in Constantinople within the frame of this activity, between 862 and 867 .

An intensification of the veneration of the Robe of the Theotokos took place at the same time (860) with no connexion to the cult of St Gregory the Illuminator or the Armenian Church politics of patriarch Photius. In 860, the Robe of the Theotokos began to be venerated as a $\Sigma \kappa \varepsilon ́ \pi \eta$. This was a personal initiative of Photius.

Under Basil I, the founder of the Macedonian dynasty, the new Byzantine cult of St Gregory became the basis of the state ideology - seen through a Byzantine adaptation of the eschatological Vision of St Sahak. This was an initiative of Photius, too. This cult, used to legitimise the future patriarch Stephen, led to the redefinition of the Robe of the Theotokos as her "omophorion," in analogy to the omophorion of a bishop.

Thus, the cult of the Pokrov of the Theotokos - employing the term omophorion - was established under the second patriarchate of Photius (867-886). This cult was connected to the veneration of St Gregory the Illuminator within the eschatological perspective of the "Byzantinised" Vision of St Sahak. However, this resulted neither in the establishment of a new feast on 1 October nor any specific veneration of St Andrew the Salos.

The cult of Andrew the Salos was called for in a later epoch, under Nicholas Mystikos (his first patriarchate, beginning in 901), as a means of substitution of the ideology of "Arshakid" priesthood, when the alleged Arshakid provenance of the Macedonian dynasty was reduced to royal succession only, and no longer encompassed the succession of the priesthood; this resulted in a laying aside of the Vision of St Sahak, which was probably replaced with the Apocalypse of Andrew the Salos. This, in turn, resulted in the establishment of the commemoration of St Andrew the Salos on 28 May, replacing the commemoration days of the discovery of the relics of St Gregory the Illuminator and the holy virgins during the time of patriarch Photius.

Thus, during the first patriarchate of Nicholas Mystikos, the preconditions allowing the establishment of the feast of Pokrov were in place. The Robe of the Theotokos became first the $\Sigma \kappa \varepsilon \dot{\tau} \pi \eta$ and then the "omophorion." The meaning of the omophorion of the Theotokos as the omophorion of the highest bishop of the City and its connexion with St Gregory the Illuminator's cult were suppressed but certainly not erased completely during the short tenure of Nicholas Mystikos's first patriarchate, from 901 to 907. 
Some traces of the earliest account of the vision of St Andrew the Salos predating the establishment of the feast of Pokrov may be preserved in the Life of St Andrew. For the sake of completeness, I review them in Note 2 below.

\section{Note 2: A Tentative Reconstruction of a Liturgical Cycle Possibly Related to the Vision of St Andrew within the Life of Andrew the Salos}

Within the Life of Andrew the Salos the story of the vision in the Holy Soros of Blachernae is preceded by episodes ${ }^{182}$ which are not formally a part of the same continuous narrative but which, nevertheless, have some liturgical value and may be interesting, if not for the study of the Pokrov feast then at least for the composition of the hagiographical novel.

The story of the Pokrov vision is preceded by the story of the miracle of St Akakios for Epiphanius, the disciple of St Andrew. At first glance, the two subsequent parts of the Life of Andrew the Salos are not connected to each other. The Akakios episode ends with the hagiographer's statement that, since that event, Epiphanius became especially devoted to St Akakios and often visited his church. The Pokrov episode, which follows, is introduced by another hagiographer's statement saying that An-

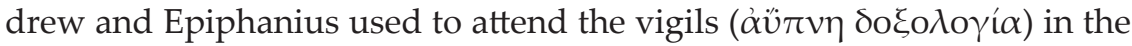

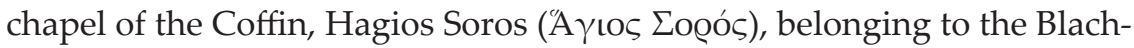
ernae Church. It is certain that the tenth-century composer of the Life of Andrew considered these two episodes as separate. But there is a clear sign that he was working with material that was, at that point in time, unfamiliar to him.

After receiving Andrew's command to go to the St Akakios Church in Heptascalos, ${ }^{183}$ Epiphanius visits the service in the church of St John the

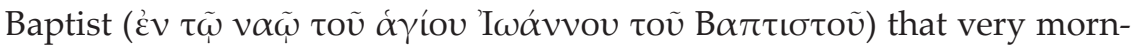
ing. Only after that does he continue on his way to St Akakios. There then follows the first vision of St Akakios in his church during vespers; the second vision of Akakios the following night, when Epiphanius was sleeping at home; and the communion in St Akakios Church on the morning of the next day, which concludes the whole story about Epiphanius and his temptation. The visit to the church of St John in this story is not only unmotivated, but stands in direct contradiction to the words Andrew ad-

(182) Rydén 1995, vol. 2, 248/249-254/255 (txt/tr.), Moldovan 2000, 592596 (Greek), Moldovan 2000, 394-399 (Slavonic).

(183) On the basilica (martyrium) of St Akakios in Heptascalos ("Seven Ladders"), see JANin 1969, 14-15. 
dressed to his obedient disciple. ${ }^{184}$ It is not good if, having been directed by your spiritual father to go to a specific place, you decide to visit a different place along the way. The John the Baptist church episode is clearly an undigested remnant of a somewhat different plot which appeared in the source used by our hagiographer.

The reference to the St Akakios Church is a clear sign of the epoch. This basilica, although it was built already by Constantine the Great and reconstructed by Justinian the Great, was in ruins before the time of Basil I (867-886); Basil rebuilt it. ${ }^{185}$ The exact date of the rebuilding is unknown but, in any case, the St Akakios Church in this text is one of the new sanctuaries of the Macedonian dynasty.

St Akakios was the martyr who died in the future Constantinople (then Byzantium) in 302/303, and so was considered as a heavenly patron of the City. As a consequence of the episodes of the Life of Andrew the Salos, St Akakios is visited and reveals visions with a miracle immediately before Andrew and Epiphanius went to the main sovereign of the City, the Theotokos in the Holy Soros. A lesser patron of Constantinople prepares the way for the City's greatest patron.

Was there, in Constantinople, a Church of St John the Baptist that was in some way remarkable in the same early Macedonian period? In this period, there were several dozen John the Baptist sanctuaries in Constantinople, so it is difficult to answer without additional information. ${ }^{186}$

However, some additional information could be provided from the text of the Life of Andrew. The Akakios episode and the following Blachernae episode are distinct from their broader context. These two stories are connected with precise sanctuaries while those that precede them ${ }^{187}$ and

(184) Andrew says to Epiphanius to go to St Akakios Church aụ́ıov $\gamma \dot{\alpha} \varrho$

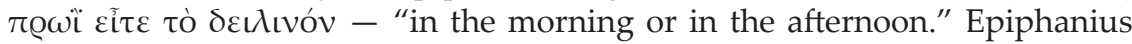
goes to St John the Baptist in the morning and to St Akakios in the afternoon.

(185) Constantine Porphyrogenete writes about this church in his Vita

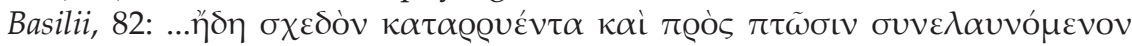

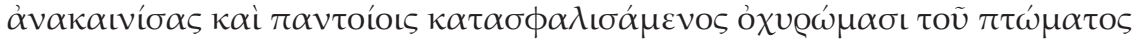

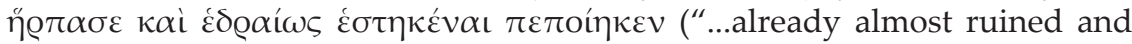
tending to tumble down he renewed [it] and, having been strengthened from everywhere by the counterforces, prevented it from tumbling down and made it stand firmly"); I. BeкKer, Theophanes Continuatus, Ioannes Cameniata, Symeon Magister, Georgius Monachus (Bonn, 1838) (CSHB) 324-325.

(186) Cf., however, above, Note 1, on the St John the Baptist oratory in the monastery of Staurakios.

(187) The Vision of St Andrew as a pillar of fire to a pious woman near the column of Constantine. 
follow them ${ }^{188}$ are not. It is tempting to consider them as a sort of "stational liturgy," especially taking into account that both the Blachernae and Heptascalos quarters are relatively close to each other, near the Golden Horn, and that there were, in the late ninth century, several John the Baptist shrines in the same area. ${ }^{189}$

If the visions of St Akakios and of the Theotokos were connected, in the source used by our hagiographer, forming a single chain of events, then the chronology was as follows:

- first day, morning: liturgy in the St John the Baptist Church;

- first day, evening: vespers in the St Akakios Church;

- second day, morning: liturgy in the St Akakios Church;

- second day, evening and third day, night: vigil in the Hagios Soros in Blachernae.

The St Akakios scene would be especially well placed in the late ninth century, when the Church of St Akakios was rebuilt by Basil I. It is difficult to judge whether the confused story about the miracle of St Akakios and the visit to some John the Baptist church had any connexion to the earliest story of the vision in Blachernae which might have circulated before the feast of Pokrov was established.

\section{Part Three: the Feast of Pokrov within the Cycle of St Gregory the Illuminator}

\subsection{The Marian Relics and the Wives of Leo the Wise}

Symeon Metaphrastes in his synaxarium entry on 31 August, the feast of the Girdle of the Theotokos, relates the story of a miraculous healing of a wife ( $\sigma \dot{\zeta} \zeta$ เ $\gamma$ os) of Leo the Wise named Zoe from an impure spirit. Leo opened the casket with the Girdle, which turned out to be absolutely uncorrupted, and "then patriarch" (unnamed) placed the Girdle on the head of Zoe, who was cured immediately. ${ }^{190}$ The story is unknown in all earlier sources. Zoe could be identified with either Zoe Zaoutzaina (died in 899; she was Leo's second wife, whom he married

(188) The denunciation of a nobleman, on the Hippodrome.

(189) At least, numbers 2 (in the monastery called "of Egyptians," near the Blachernae wall), 26 (in Petra), 30 (in the monastery of Staurakios, see

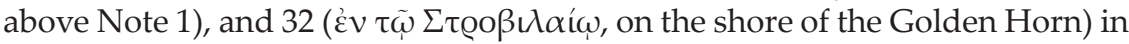
the list of Prodromos shrines in JANIN 1969, 410, 421-429, 430, 440.

(190) In Menologium Basilii Porphyrogeniti, PG 117, 613 AB. The Girdle was

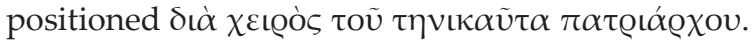


soon after the death of Theophano in November of 895 or 896, and she had been his mistress much earlier) or Zoe Carbonopsina (his fourth wife, from 905 to 912, and his mistress from about 904).

This story about the opening of the casket containing the Girdle is related in a more historical way by patriarch Euthymius in his homily on the feast of the Girdle of the Theotokos and on the encaenia of the Holy Soros of Chalkoprateia celebrated on the same day (31 August). ${ }^{191}$ The homily was delivered when the memory of the discovery of the Girdle in an absolutely perfect condition was still fresh. Eu-

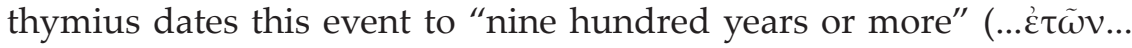

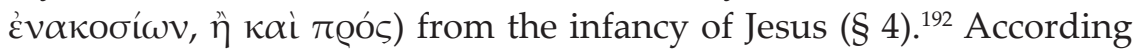
to the traditional Byzantine chronology, which dates the birth of Jesus to AM 5500, this results in $5500+900=$ AM 6400 (892 AD) as the terminus post quem. This date is compatible with both Zoe Zaoutzaina and Zoe Carbonopsina. Euthymius, however, does not say a word about either of them, nor does he mention the name of the current emperor, although it is evident from the chronology he provides that the only possible emperor here is Leo VI.

(191) M. Jugie, Homélies mariales byzantines. Textes grecs édités et traduits en latin (Paris, 1922) [repr.: Turnhout, 2003] (PO, 16,3; N 79) 503-514 [81-90].

(192) Jugie, Homélies mariales..., 510 [86]. This dating is interpreted by Jugie as 880/884, supposing that the Theotokos gave birth to Jesus when she was between 16 and 20 years old. Jugie makes a mistake in presupposing that the age of the Girdle is the same as the age of the Theotokos (whereas, according to the homily, it is the same as the age of Jesus). Then, Jugie himself disregards his own computus by placing the event under the first months of the patriarchate of Stephen, before the moment when Euthymius was made syncellus (ibid., 479-480 [55-56]). Such a strange supposition seems to have no other basis than the wish to avoid acknowledging the high esteem in which Euthymius held Photius (cf. ibid., 488-489 [64-65]). In fact, dating the homily to Photius' time is excluded on purely chronological grounds. Janin dates the homily to "vers 888," without explanation (JANIN 1969, 238; cf. here n. 10, which is probably an erroneous repetition of n. 11). In this he was apparently following Jugie, although with a precision based on ch. 4 of the Vita Euthymii, where it is stated that, before becoming syncellus, Euthymius arrived in the imperial palace for the first time after an absence of two and one-half years. Supposing (and this is only a guess) that the previous visit of Euthymius took place somewhere during the reign of Basil I in the first half of 886, one arrives at 888 as the date when Euthymius became syncellus. For Jugie and probably for Janin, too, fundamental to the dating is the fact that, in the title of the homily, Euthymius is called "monk" but not "syncellus," unlike the title of another homily of his authorship, where he is called "presbyter and syncellus." 
This homily, together with the silence of the chroniclers, proves that the story about the healing of a wife of Emperor Leo is fictitious one cannot take it at face value. ${ }^{193}$ This is not to say, however, that the story is of no value for historians. Both Zoe Zaoutzaina and Zoe Carbonopsina were associated with severe spiritual temptations and Church troubles. However, the role of Euthymius in these two affairs was quite different. Euthymius never accepted the marriage with Zoe Zaoutzaina, knowing that she was Leo's mistress when his first wife, Theophano, was still alive. Euthymius severed communication with his spiritual son Leo until Zoe's death. Leo received a dispensation for the marriage, with Zoe Zaoutzaina from patriarch Antony Kauleas (893-901), who became the principal peacemaker in this affair. But in the tetragamia affair it was Euthymius - acting as the patriarch - who became the key figure in the readmission of Leo to the Church. Leo was excommunicated for his fourth marriage with Zoe Carbonopsina, and his readmission to the Church was certainly worthy of representation in the symbolic imagery of a hagiographical legend. However, the possibility that the legend represents the story with Zoe Zaoutzaina and patriarch Antony Kauleas cannot be excluded a priori, even if the troubles provoked by this story are not nearly as serious as those relating to the tetragamia affair.

In any case, the legend says that the casket with the Girdle of the Theotokos was opened under Leo the Wise as a means of overcoming the temptations provoked by Leo's marriage with one or another of the Zoes. This is the only available and quite reasonable explanation of a historical fact testified by the homily of Euthymius - that Leo resorted to the relic to cure his wife.

It is tempting to consider the homily as having been delivered when Euthymius was patriarch and to identify its historical context in terms of the tetragamia affair. Such a treatment is provided by Wortley, ${ }^{194}$ and it seems to me the most natural. However, for the sake of completeness, I would like to re-evaluate this conclusion.

There are two important arguments against Wortley's dating of the homily:

(1) The title of the homily, in which its author, Euthymius, is called "monk," without indication of his patriarchal title (this reading appears in both manuscripts used in Jugie's edition). Wortley responds

(193) As Jugie does uncritically (ibid., 485 [61]).

(194) Wortley 2005, 176, n. 17. Cf. note 192 about Jugie's interpretation. 
by noting that Euthymius was a monk before his elevation as well as during his patriarchate and after his deposition. Wortley's treatment of the title is partially corroborated by the attitude toward the Euthymian patriarchate at the time of the second patriarchate of Nicholas Mystikos (cf. above, 1.7.3, on the possibility of a deliberately anonymous transmission of his homiletic legacy). The original titulature of patriarch Euthymius could have been censored later, when the official Church considered his patriarchate as illegitimate (during the period from, at least, 912 to 920). Thus, I agree with Wortley that the titulature of the author of the homily in its title is not important in dating the work.

(2) Euthymius' statement that he is preaching from obedi-

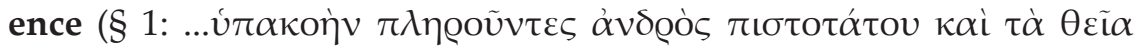
$\dot{\varepsilon} \mu \pi \varepsilon \pi \lambda \eta \sigma \mu \varepsilon \dot{v} \mathrm{vov}^{195}$ - "...performing obedience to the man most faithful and filled with divine (things)"). It is not common for patriarchs to preach as a demonstration of obedience to other men. Wortley does not mention this difficulty.

If Euthymius were patriarch, such a phrase would indicate the emperor; if the phrase were pronounced before Euthymius' patriarchate, it would indicate instead a patriarch (either Antony Kauleas or Nicholas Mystikos), because, in Church matters, if Euthymius were not patriarch, he would not have been directly subordinate to the emperor. However, the wording of the phrase is rather revealing. The epi-

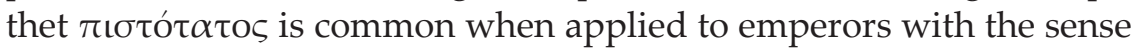
"most Christian" 196 but would be redundant if applied to the clergy (the second epithet is the equivalent of $\theta \varepsilon$ เó $\alpha \tau \tau$,, which is applicable to different kinds of people). Thus, the man who asked Euthymius to preach was Leo the Wise.

If this is indeed the case, the homily is to be dated to the patriarchate of Euthymius. Moreover, it is extremely unlikely that Euthymius would have been asked to preach on the memory of an event that helped to legalise Leo's marriage with Zoe Zaoutzaina: Leo eventually acknowledged Euthymius' right not to accept this marriage. However Leo's demand fits perfectly into the high stakes of the tetragamia affair.

Our considerations corroborate Wortley's view on the historical place of the homily of Euthymius. It is datable to the patriarchate of

(195) Jugie, Homélies mariales..., 506 [82].23-24. Jugie identifies this man with patriarch Stephen (ibid., 480 [56]), which is obviously an anachronism.

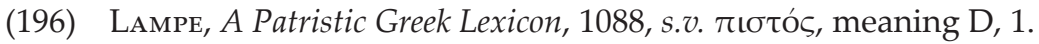


Euthymius, and Leo resorted to the Girdle of the Theotokos because of his troubles due to his fourth marriage, to Zoe Carbonopsina.

Thus, under Euthymius' patriarchate, the cult of the Girdle became involved in the tetragamia affair. This is an indirect but strong proof that the cult of the maphorion, even more popular in this epoch, was used as a weapon in the same affair, too - in the lines described in the first part of this study, where the establishment of the feast of Pokrov was hypothetically ascribed to patriarch Euthymius. This original hypothesis has been strengthened, but is still unproven. To go further, we have to look at the Constantinopolitan liturgical calendar around 1 October.

We have seen above (2.4.6) that the cult of the maphorion of the Theotokos was influenced by the cult of St Gregory the Illuminator. The Theotokos herself was considered as the locum tenens of the future patriarch of the Roman Empire, who was to be a descendent from the stock of the Arshakids and who is the legitimate owner of the omophorion of St Gregory the Illuminator. Thus, the proximity of the feast of Pokrov to the St Gregory cycle within the Constantinopolitan liturgical calendar is worth examination.

\subsection{The Symbolic Nature of the Date 1 October}

Any explanation of the establishment of the feast of Pokrov must account for the choice of the date 1 October. The simplest explanation would be possible, of course, if the event commemorated (the vision of Andrew the Salos and Epiphanius) had occurred on 1 October. This is not the case, however. The feast was not established immediately after the event (see above, 1.8.1), the date of which, in any case, was never specified exactly in any of the sources. In the Life of Andrew the Salos the corresponding event is loosely inscribed into a kind of stational liturgy connecting the Holy Soros of Blachernae with some church of John the Baptist and the church of St Akakios (see above, Note 2), but the known feasts of the corresponding saints and sanctuaries are remote from 1 October. Moreover, the original date of the commemoration of St Andrew the Salos himself, on 28 May (see above, 2.1), is also remote from 1 October.

Therefore it is unlikely that the date 1 October is, in any way, a historical one. On the contrary, it is very likely that it is symbolic. It must be explained by means of an examination of the structure of the Church calendar rather than by the chronology of historical events. However, looking at the Constantinopolitan Church calendar, we see 
immediately that the closest neighbours of the feast of Pokrov are our old friends St Gregory the Illuminator (30 September, on the eve of Pokrov), Rhipsime (26 September), and Gaiane (27 September).

\subsection{The Autumn Commemorations of St Gregory the Illuminator and His Companions in Constantinople}

The historical days of the martyrdom of the holy virgins are indicated in the Armenian Agathangelos (Aa) as 26 and 27 Hori, which are rendered in the Greek version of the Agathangelos (Ag) as 26 and 27 September. The historicity and genuineness of these dates has been demonstrated, most recently, by Jost Gippert, who placed the Agathangelos data in the context of early Georgian sources. ${ }^{197}$

Of course, the correspondence between the Hori of the old Armenian movable year and the Julian September is very rough (and, moreover, changing at the rate of one day every four years), but here, once more, we are dealing with one of the most popular "techniques" of the translation from one liturgical calendar to another.

In the available recensions of the Synaxarium of Constantinople, only the commemoration of 27 September is preserved (for Gaiane, but together with Rhipsime and the other virgins). In later recensions, even this commemoration is shifted to 30 September, on the same day as St Gregory the Illuminator. ${ }^{198}$ Since the early second Christian millennium, this commemoration of St Gregory together with Gaiane and Rhipsime and those with them on 30 September becomes normative for the Byzantine rite. Thus, for the tenth century, at least, the commemoration of Gaiane on 27 September was still preserved.

The separate commemoration of Rhipsime on 26 September is well attested in the Coptic rite, which preserves the commemoration of Rhipsime and Gaiane together on 26 September (29 Tot), ${ }^{199}$ and, moreover, the commemoration of Gregory the Illuminator on 27 Septem-

(197) J. Gippert, Old Armenian and Caucasian Calendar Systems. 2. Armenian hori and sahmi, The Annual of the Society for the Study of Caucasia 1 (1989) 3-12. The historical facts here are the atrocities against the Christians during the invasion of Armenia by the Roman emperor Maximinus Daia in 311-312 (cf. Peeters 1942, 105-106).

(198) See Synaxarium CP, col. 83, 85 and 89-93.

(199) R. BAsset, Le Synaxaire arabe jacobite (rédaction copte). Texte arabe publié, traduit et annoté (Paris, 1904) (PO 1, 3) 306 [92] - 308 [94]. 
ber (30 Tot). ${ }^{200}$ If some Byzantine tradition borrowed the 26 September commemoration date, the same commemoration should also be found in the Syrian Jacobite rite as well, for this rite was very close to Byzantine liturgical traditions up to the middle of the sixth century. In fact, most of the Syrian Jacobite calendars do not have any commemoration date for Rhipsime. However, there is one among them (from the fourteenth century) that contains the commemorations of Rhipsime, Gaiane, and Gregory on 26, 27, and 30 September respectively, ${ }^{201}$ and there is another one (from the twelfth or thirteenth century) containing a separate commemoration of Rhipsime (with other virgins, unnamed, but without St Gregory), but on 28 September. ${ }^{202}$ The Jerusalem rite of the first millennium did not know the commemorations of 26 and 27 September at all..$^{203}$

Such a distribution correlates with the distribution of the commemoration of the great feast of John the Theologian on 26 September, a powerful liturgical tradition of Ephesus and the patriarchate of Antioch. ${ }^{204}$ It was accepted in Constantinople and Jerusalem, but in the Syrian Jacobite rite it was accepted in some local traditions only. The feast of Rhipsime on 26 September is incompatible with another great feast on the same day, and so it was shifted to 27 September. It was

(200) Lacking in the Coptic Synaxarium but preserved in other calendrical manuscripts: F. NAU, Les ménologes des évangéliaires coptes-arabes édités et traduits (Paris, 1913) (PO 10, 2) 189 [25]. Preserved also in the Ethiopic Synaxarium on the same day $=30$ Maskaram: G. Colin, Le Synaxaire éthiopien. Mois de Maskaram. Édition critique du texte éthiopien et traduction (Turnhout, 1986) (PO 43, 3, N 195) 504/505 [186/187] (txt/tr.).

(201) P. Peeters, Le martyrologe de Rabban Sliba, AB 27 (1908) 129-200, here 161-162/196-197 (txt/tr.).

(202) Calendar Nau IX: F. NAU, Un martyrologe et douze ménologes syriaques, édités et traduits (Paris, 1912) (PO 10, 1) 107 [107]. The same date for both Gaiane and Rhipsime in the marble calendar of Naples (ca 821-841): PeEters 1942, 92.

(203) Cf., as a comprehensive introduction to the Jerusalem calendars, G. GARITTE, Le calendrier palestino-géorgien du Sinaiticus 34 ( $X^{e}$ siècle). Édité, traduit et commenté (Bruxelles, 1959) (SH 30).

(204) In Ephesus, John the Theologian was the principal saint. His death was celebrated on the day of the autumn equinox (26 September for the early Christian centuries) which, in the region of Ephesus, was the beginning of the year from antiquity (however, the Christian liturgical calendar started on 1 October). 
preserved on 26 September in the Coptic rite, where the feast of John the Theologian is absent on this day.

For Constantinople $c a 900$, it is certain that 26 September was the feast of John the Theologian, while 27 September was the commemoration of Gaiane together with Rhipsime and the other virgins.

As to the Byzantine commemoration of St Gregory the Illuminator on 30 September, the question of its origin needs to be reopened despite a widely accepted hypothesis put forward by Paul Peeters (see Excursus below). My own conclusion is that this date represents an ancient Armenian tradition whose roots were forgotten even in the Armenian Church and which was accepted in Constantinople long before the Macedonian period (together with the cult of St Gregory the Illuminator itself, that is, in the sixth century and certainly not later than in the seventh).

Regardless of the historical origin of the commemorations of 27 and 30 September, they were perceived as connected to each other, that is, as a kind of liturgical cycle with 30 September as its most important day. This is why, when the Armenian saints became less actual for Byzantium and the cycle collapsed, it resulted in the common feast of all these saints that was held on 30 September.

\subsection{The Choice of 1 October for the Pokrov Feast}

Up to the first years of the tenth century, the maphorion of the Theotokos became a powerful symbol of divine protection. It was connected with the Theotokos' role as supreme bishop of the City, and even the memory of the identity of the Theotokos' omophorion with that of St Gregory the Illuminator was fresh. Moreover, we know that at least one Marian relic, the Girdle, was used as a means of overcoming the internal Church conflict provoked by the fourth marriage of Leo the Wise.

After the deposition of Nicholas Mystikos and the enthronment of patriarch Euthymius in 907, the situation echoed, in some ways, the situation that had prevailed with patriarch Stephen before and especially after his consecration. Once more, the canonical rights of the new patriarch were less than obvious, and so, once more, an intervention on the part of the Theotokos was welcome.

As we have seen above (part One), the feast of Pokrov had also been established as a way of overcoming an internal Church conflict. The proposed history of its appearance under patriarch Euthymius and its disappearance after a short time during the second patriarchate of 
Nicholas Mystikos fits perfectly within the context of the specific Theotokos cult of $\mathrm{ca} 900$ and the circumstances of the tetragamia affair in 907. Shortly after this time, that is, around the end of the first half of the tenth century, the omophorion of the Theotokos lost its meaning as a bishop's garment and became a simple maphorion.

The fact that the commemoration of the vision of the Theotokos was appointed on 1 October, the day immediately following the feast of St Gregory the Illuminator, is especially revealing, given that the Robe of the Theotokos was reconsidered as a bishop's omophorion within the cult of St Gregory which, in turn, had been reshaped under the influence of the Byzantine adaptation of the Vision of St Sahak.

At a time no later than the first patriarchate of Nicholas Mystikos, the second Constantinopolitan commemoration of St Gregory, in May, was abrogated. However, the commemoration of St Andrew the Salos (28 May) was retained in the liturgical cycle that had been established at that time (26-28 May). The feast commemorating St Andrew had been established to replace a commemoration of the vision of St Sahak (s. above, 2.3.4). Thus, the only way to reestablish an additional feast related to St Gregory was to put it within the established Byzantine cycle of St Gregory in the neighborhood of 27 and 30 September. In so doing, patriarch Euthymius was referring to the memory of the identity between the omophorion of the Theotokos and the omophorion of St Gregory the Illuminator from the Vision of St Sahak. This memory had been suppressed a few years earlier by Nicholas Mystikos, but during the tetragamia affair the authority of Nicholas Mystikos was severely undermined.

Another hint regarding the establishment and placement of these feasts is provided by the personalities of the two main saints who appeared in Andrew's vision together with the Theotokos, St John the Forerunner and St John the Theologian. The presence of these particular saints must have an explanation, but so far no scholar has been interested in exploring it, despite the obvious fact that an arbitrary choice is no more likely here than, say, in the scene of the Transfiguration of Jesus. But while in the latter case, the traditions that underlie the appearance of Moses and Elijah are understood and have continued to be studied, in our case, the very need to pose such a question is unrealised.

The choice of St John the Theologian is perfectly comprehensible in terms of the calendar. The date 26 September, the commemoration of the repose of St John the Theologian, is the last major feast before 1 October. 
In the Greek hagiographical dossier of St Gregory, this day is, moreover, the first day of the commemoration of the holy virgins accompanying St Gregory. The day of the martyr death of Rhipsime, 26 September, would have been kept in mind even by those who were celebrating her commemoration on the next day, together with Gaiane. The presence of St John the Theologian in the vision of St Andrew the Salos marks the beginning of the corresponding liturgical cycle, 26 September.

The presence of St John the Baptist in Andrew's vision is, at first glance, unmotivated. The Life of Andrew the Salos does not demonstrate any specific reverence toward this saint. The scene of the visit of Epiphanius to a church of St John the Baptist on his way to the church of St Akakios is interesting, but this episode as it is preserved in the form transmitted in the hagiographical novel seems to be corrupted irreparably (s. Note 2). If we looked for a calendrical analogy to the appearance of St John the Theologian, we would expect not the appearance of John the Baptist, but rather St Gregory the Illuminator. But the descriptions of the vision of St Andrew, both in his Life and in the sermon in the Russian Prolog, agree that the Theotokos appeared in the company of St John the Theologian, St John the Forerunner, and "many other" but unnamed saints. Why are these saints not Gregory the Illuminator together with the holy virgins?

To have imagined St Gregory the Illuminator on such a distinguished place near the Theotokos in the heavens above Constantinople would have been difficult even in the time of Basil I. In the early tenth century, such a position for St Gregory would have been absolutely unthinkable. However, Gregory's common epithet, "Illuminator" (Lnuuulnnhy), coincided with that of another Illuminator who was especially popular in Constantinople, John the Baptist. The very word

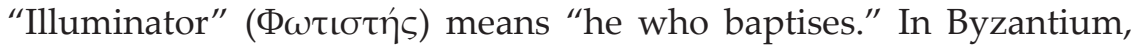
the common title of St Gregory was "the Illuminator of Great Armenia." This title would be inappropriate as the name of the protector of Constantinople, but it made the figure of St Gregory interchangeable with that of John the Baptist. Thus, in the vision of St Andrew, St John the Baptist replaced St Gregory the Illuminator.

The feast of 1 October was arranged along the lines of the previous (pre-901, that is, before the patriarchate of Nicholas Mystikos) cult of St Gregory the Illuminator. Most probably, the commemoration of St Andrew on 2 October appeared together with the Pokrov feast itself, both as its afterfeast and also as the concluding day of the seven-day cycle starting on 26 September. 
The choice of the date 1 October is explainable in the same context as the choice of the omophorion of the Theotokos as a protective means for the see of Constantinople when its patriarch had insufficient canonical rights. This context is the cult of St Gregory the Illuminator in its forms specific to the early Macedonian period. Such a meaning of the omophorion of the Theotokos existed for only a short time, and this short time coincided precisely with the timeframe indicated on the basis of the Slavic milieu (s. part One).

The two lines traced in the present study, one working back from the Slavonic sources and the other working forward from the Armenian and Byzantine sources, meet on 1 October of 907, the first year of the patriarchate of Euthymius, soon after the deposition of Nicholas Mystikos. ${ }^{205}$

\section{Excursus: St Gregory the Illuminator's Feast on 30 September}

\section{Peeters' Hypothesis}

The earliest attestation of the feast of St Gregory the Illuminator on 30 September is the Naples marble calendar datable to $c a 821-841 .{ }^{206}$ All the Oriental witnesses are much later, including the Synaxarium of Constantinople (ninth-tenth century) and various Armenian and Syriac liturgical documents (available from the early second millennium). Thus, Paul Peeters concluded that the presence of this commemoration of St Gregory in the Armenian tradition (and, I would add, the Syrian Jacobite one as well) is secondary and dependent on the calendar of Constantinople. ${ }^{207}$

The Constantinopolitan date 30 September has, in turn, an Armenian origin. Here I agree with Peeters, but I differ with him in some of the details. According to Peeters, 30 September is a Julian rendering of the date of the principal feast of St Gregory in the Armenian calendar

(205) I would like to express my gratitude to John Wortley for his advice and to Kirill Khrustalev, Sergei Ivanov, Vera Zemskova, Elena Bormotova, Tatiana Senina, Andrei Orlov, Pavel Lukin, Alexandre Kananyan, and Eugen Shteyn for their assistance in my work, as well as to Claudia R. Jensen for improving my English.

(206) For the publication of this calendar with a study, see H. Delehaye, Hagiographie Napolitaine. I, AB 57 (1939) 5-64.

(207) Peeters 1942, 128-130; for the Syrian Jacobite calendars, see the data in NAU, Un martyrologe...; for a more complete review of the Armenian data, see AKInEAn 1947. 
on 10 (sometimes 11) $\mathrm{K}^{\prime}$ ałoc $^{\prime}$, which commemorates his vision of the Heavenly Tabernacle with the pillar of light and Jesus Christ in person over the site of the future Cathedral of Etchmiadzin. According to Peeters, the correspondence between 10/11 K'ałoc' of the Old Armenian movable year and 30 September points to the years $752-750$ as the time of the establishment of the Byzantine feast on 30 September. ${ }^{208}$ Peeters' idea that the Byzantine Julian dates could be derived from the Armenian movable dates is insightful and, applied to the December commemorations of Gregory the Illuminator, ${ }^{209}$ is now proved to be true. ${ }^{210}$ Nevertheless, it does not work for 30 September. First of all,

(208) Peeters 1942, 129 and n. 3. Peeters mentions Nicholas Marr's datings of different recensions of the Agathangelos (from the seventh to the eighth century) as possible evidence of an interest in the cult of St Gregory at this time. However, these dates are either too late (for $\mathbf{A a}$ and $\mathbf{A g}$ ) or unfounded (for $\mathbf{V g}$ and the lost Greek original of Va; cf. above, 2.4.5). Peeters' calculation seems a bit inexact. If 30 September renders $11 \mathrm{~K}^{\prime} \mathrm{ałoc}^{\prime}$, the corresponding four years are 748-751; if $10 \mathrm{~K}^{\prime} \mathrm{ałoc}^{\prime}, 744-749$. Cf. É. Dulaurier, Recherches sur la chronologie arménienne technique et historique (Paris, 1859) 385 (in Tableau A, the years where 1 Navasard corresponds to 24 and 23 May).

(209) Peeters explains two commemorations of Gregory of Armenia in the Naples calendar on 2 and 3 December as renderings of 11 and $10 \mathrm{~K}^{\prime}$ ałoc' for the years 496-504 (Peeters 1942, 125). Peeters' calculations need to be slightly corrected: the interval in question is $488-499$, which seems to be, nevertheless, within the same period of the Church history of the Christian East. 2 December $=10 / 11 \mathrm{~K}^{\prime}$ ałoc $^{\prime}$ for the years 492-495/496-499 (1 Navasard = 26/25 July), 3 December $=10 / 11 \mathrm{~K}^{\prime} \mathrm{ałoc}^{\prime}$ for the years 488-491/492-495 (1 Navasard = 27/26 July); Dulaurier, Recherches..., 384 (in Tableau A). December commemorations of St Gregory are known to the Coptic and Jacobite Syrian rites, but on other days. In the Byzantine tradition, they disappeared completely, although this tradition was the source of the calendar of Naples and probably also of some Oriental calendars.

(210) In light of the Karshuni version (Vk), whose lost Armenian archetype is datable to 604-610 [M. van EsBroecK, Un nouveau témoin du livre d'Agathange, Reoue des études arméniennes 8 (1971) 139-221]. Vk testifies to the historicity of the Church unity between the Armenians, the Georgians, the Albanians, and the Laz in the late fifth century, on the eve of the First Council of Dwin (506), where all these nations rejected the Council of Chalcedon (for all this see van Esвrozск 1971). The legend of the common Baptism of all these peoples by St Gregory the Illuminator in Bagavan is proper to the recensions of the series $\mathbf{V}$ and unknown to the "national" Armenian recensions of the series $\mathbf{A}$. The early date of the Armenian original of Vk proves the existence, $c a$ 500, of the feast of St Gregory in commemoration of this (fictitious) Baptism of the four nations in Bagavan. Taking into account Peeters' calculation, it results 
Peeters is unable to identify any historical event affecting the Byzantine cult of St Gregory precisely at this time. Moreover, there is a series of facts unknown to Peeters but important to the history of the cult of St Gregory which allows another explanation of the origin of the commemoration on 30 September.

Peeters explained why the earliest commemoration date of the vision of St Gregory is 10/11 K'ałoc'. The corresponding liturgical cycle is described in the text of the Armenian Agathangelos and its derivates. The cycle starts on 26 Hori, the martyrdom of Rhipsime. A period of nine days then follows, during which Trdat has time to put Gaiane and the other virgins to death, to be transformed into a wild boar, to repent, to remove St Gregory from the cave after fifteen years of imprisonment, and to be healed by St Gregory. After this, there are sixtysix days of the catecheses of St Gregory to Trdat and those with him. On the sixty-fifth day of these catecheses (the penultimate day of the whole cycle), the miraculous vision of Christ occurs. The entire cycle thus takes seventy-five days $(9+66)$. Its first day is 26 Hori and its

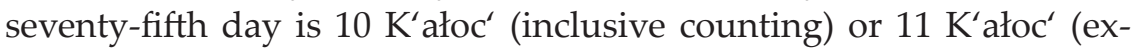
clusive counting), which implies that the day of the vision was 9 or $10 \mathrm{~K}^{\prime}$ ałoc $^{\prime} .{ }^{211}$ There is no attested date of commemoration on $9 \mathrm{~K}^{\prime} \mathrm{ałoc}^{\prime}$, and thus it is $10 \mathrm{~K}^{\prime}$ ałoc $^{\prime}$ that is to be taken as the genuine date of the feast dedicated to the vision of St Gregory.

The commemoration of $10 \mathrm{~K}^{\prime}$ ałoc' is preserved in the Armenian calendar up to the present. It is certainly in perfect conformity with the early tradition preserved in the Agathangelos. It is therefore all the more perplexing that the main commemoration of the vision of St Gregory eventually became the eve of the Dormition of the Theotokos, which is also the day of the encaenia of the Cathedral of Etchmiadzin. It is

in a date of around 500 for the establishment of the feast on 10/11 $\mathrm{K}^{\prime} \mathrm{ałoc}^{\prime}$ (I would prefer a bit earlier date, the beginning of the catholicosate of Babken I (490-516)) in Bagavan as the common feast of the four nations. The meaning of the feast was in celebration of a discovery of the relics of St Gregory, whose relics were the principal sacred object in Bagavan; its reconsideration as the feast of Šołakat' ("effusion of light" which is a commemoration of the vision of St Gregory) may be secondary (as van Esbroeck seemed to think) or, alternatively, the very discovery of the relics was appointed on the day of Šotakat'.

(211) Cf. Peeters 1942, 113. It seems that originally the feast occupied two days, 10 and $11 \mathrm{~K}^{\prime}$ ałoc' (the seventy-fourth and seventy-fifth days of the cycle), which is corroborated by the calendar of Naples with its commemorations of Gregory on both 2 and 3 December. 
this feast that is normally called Tnqulyup (Šołakat" - "Effusion of Light"), ${ }^{212}$ and the same name, Šotakat', was applied to the cathedral itself in sources from the early seventh to the tenth/eleventh century. ${ }^{213}$ For the latter feast, the cycle reported in the Agathangelos (starting on 26 Hori) is broken, but another connexion was established - with the feast of the Dormition of the Theotokos. It is to be noted that the Agathangelos in all its recensions is silent about the cult of the Theotokos.

\section{The Dormition of the Theotokos and the Dedication of the Cathedral of Etchmiadzin}

The intervention of the cult of the Theotokos is not so strange if we recall that the Cathedral of Etchmiadzin - the very cathedral whose construction was revealed to St Gregory in his famous vision - is dedicated to the Theotokos, and this is why the day of its encaenia is on the eve of the Dormition (in the same manner, as, in Jerusalem, the encaenia of the Church of Resurrection is on the eve of the Exaltation of the Holy Cross, 13 and 14 September, respectively). Unfortunately, in the early sources the dedication of the Cathedral of Etchmiadzin is not attested directly, despite the fact that the late priestly tradition assumed that the dedication to the Theotokos went back to the fourth century ${ }^{214}$ (which is, of course, absolutely impossible).

(212) In the current Armenian calendar, the Dormition is the nearest Sunday to its fixed date, 15 August of the Julian calendar (= 5 Navasard of the fixed Armenian calendar created by Hovhannes Sarkavag in the early twelfth century and applied retroactively from the date 1084). The feast of Solakat' is, thus, the Saturday before this Sunday. Its fixed date is 14 August $=4$ Navasard of the fixed calendar.

(213) Cf. A. Plontke-Lünning, Frühchristliche Architektur im Kaukasus. Die Entwicklung des christlichen Sakralbaus in Lazika, Iberien, Armenien, Albanien und Grenzregionen vom 4. bis zum 7. Jh. (Wien, 2007) (Österreichische Akademie der Wissenschaften. Philos.-hist. K1. Denkschriften, 359; Veröffentlichungen zum Byzanzforschung, 13) 168-173, esp. 169. For the Cathedral of Etchmiadzin, see, first of all, А. Ю. КАзАРян, Кафедральный собор Сурб Эчмидзин и восточнохристианское зодчество IV-VII веков [A. Yu. KazAryan, The Cathedral of Holy Ejmiacin and the Eastern Christian Architecture of the $4^{\text {th }}-7^{\text {th }}$ Centuries] (Москва, 2007) (with a detailed English résumé, p. 210-214).

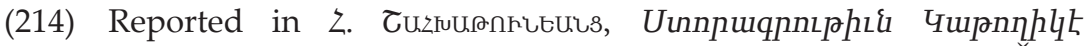

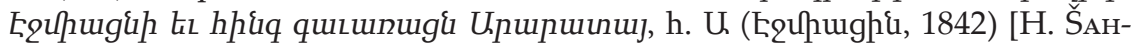
XAT'UNEANC', A Description of the Cathedral of Etchmiadzin and of five gavars of Ararat, vol. 1 (Etchmiadzin, 1842)] 16; quoted uncritically in КАЗАРян, Кафедральный собор Сурб Эчмидзин..., 19 and 186, n. 86. 
However, regardless of the earliest dedication of the Etchmiadzin cathedral in the fourth century, its rededication to the Theotokos and especially to the Dormition of the Theotokos would be fitting in 484, when the cathedral was rebuilt by Vahan Mamikonean after its devastation. ${ }^{215}$ It was a time of a rapid spread of new forms of the Theotokos cult throughout the Eastern Christian world. Among these forms, the most important was a new feast of the Dormition which had its main shrine in Gethsemane near Jerusalem. The feast was established after 438 and before 449 (probably in 444) on 7 August, but then switched to later dates. Constantinople and the Caucasus (unlike Egypt) followed the Jerusalem rite, where the Dormition absorbed an earlier Jerusalem feast of the Theotokos on 15 August (formerly the Annunciation), resulting in the Dormition cycles with the principal dates 13 and 15 August. Unfortunately, we know little about the Dormition cult in Armenia in the late fifth and the early sixth centuries. ${ }^{216}$ An interesting liturgical rubric in the title of a sixteenth-century manuscript of an Armenian transitus identifying the Dormition date of 15 August with 25 Navasard $^{217}$ (instead of the expected fixed date 5 Navasard) may be a remnant of the epoch when 15 August as the Dormition date was adopted: from 508 to 511, when 25 Navasard was the equivalent of

(215) КАЗАРян, Кафедральный собор Сурб Эчмиадзин..., 15, 185 (notes).

(216) For details, see Lourié 2010, 180-183, with further bibliography. A pre-Justinianic cycle persisted for several centuries in the Georgian tradition (abrogated, in Constantinople and Jerusalem, by Justinian in 543 after the construction of the Nea church in Jerusalem). This pre-543 Dormition cycle occupied the days from August 13 (the gathering of apostles in Sion) to 16 (the empty tomb episode), with the Dormition on August 15. An earlier cycle in the Syriac Transitus S 3 (uncertain date in the second half of the fifth century) presupposed August 13 as the very day of the Dormition. The Georgian cycle of the sixth century may be identical to that of the contemporary Armenian Church, but this supposition is far from certain.

(217) Armenian Transitus AM 6 (under the name of John the Theologian), which is a translation of the Greek epitome G 6 of the Transitus G 3 (John of Thessalonica, + 630); cf., for classification of these Transitus, S. J. Shoemaker, The Ancient Traditions of the Virgin Mary's Dormition and Assumption (Oxford, 2002) (Oxford Early Christian Studies) 421. Diplomatic edition of one manuscript (among several known ones): T. DAsnabedian, Une récit arménien du Pseudo-Jean l'Evangéliste sur la Dormition, Armach 1 (1992) 27-38 [repr.: EADEM, La Mère de Dieu : Études sur l'Assomption et sur l'image de la très-sainte Mère de Dieu (Antélias, 1995) 51-72]. The liturgical rubric in the title seems not to be a part of the text. 
15 August - the epoch of the catholicos Babken and the First Council of Dwin.

After 484, when the see of Etchmiadzin was dedicated to the Dormition of the Theotokos, an intervention of the Theotokos cult into the cult of St Gregory the Illuminator became unavoidable. It resulted, as we will see below, in a new St Gregory cycle that ran from the Dormition to 30 September and which was founded, albeit with some violations, on the basis of the Agathangelos. Indeed, the Agathangelos does contain a cycle of dedications of churches, although with no connexion to Etchmiadzin. This cycle is connected to the process of the Baptism of Armenia, although the cycle containing the vision of St Gregory is connected to earlier events (specifically, the conversion of Trdat).

\section{The Dates of the Baptism of Armenia in the Agathangelos}

The chronology of the events relating directly to the Baptism of Armenia described in the Agathangelos is as follows:

\begin{tabular}{|c|c|c|c|c|}
\hline Date & Place & Event & Aa $(\S)$ & Notes \\
\hline $\begin{array}{l}1 \text { Nava- } \\
\text { sard }\end{array}$ & $\begin{array}{l}\text { Ashtishat } \\
\text { in Taron }\end{array}$ & $\begin{array}{l}\text { Destruction of } \\
\text { pagan temples. Es- } \\
\text { tablishment of the } \\
\text { feast of St John the } \\
\text { Baptist and St Athe- } \\
\text { nogenes instead of } \\
\text { the pagan feast of } \\
\text { the New Year }\end{array}$ & $\begin{array}{l}809 \\
\text { and } \\
836\end{array}$ & $\begin{array}{l}\text { Ashtishat was the } \\
\text { principal cultic } \\
\text { centre of pagan } \\
\text { Armenia, where } \\
\text { the New Year's } \\
\text { festival was one of } \\
\text { the most impor- } \\
\text { tant celebrations. }\end{array}$ \\
\hline 20 days & Taron & $\begin{array}{l}\text { Baptism of the peo- } \\
\text { ple and building of } \\
\text { the churches }\end{array}$ & $\begin{array}{l}809- \\
814\end{array}$ & \\
\hline $\begin{array}{l}\text { One } \\
\text { month }(= \\
30 \text { days })\end{array}$ & $\begin{array}{l}\text { The whole } \\
\text { of Arme- } \\
\text { nia, from } \\
\text { Taron to } \\
\text { Bagavan }\end{array}$ & $\begin{array}{l}\text { Gregory travels } \\
\text { around the whole } \\
\text { of Armenia while } \\
\text { King Trdat waits } \\
\text { for him in Bagavan }\end{array}$ & 817 & $\begin{array}{l}\text { In the Armenian } \\
\text { calendar, all the } \\
\text { months contain } \\
30 \text { days. }\end{array}$ \\
\hline $\begin{array}{l}\text { When one } \\
\text { month } \\
\text { was spent }\end{array}$ & Bagavan & $\begin{array}{l}\text { Meeting of Gregory } \\
\text { and Trdat }\end{array}$ & 817 & $\begin{array}{l}\text { On the } 50^{\text {th }} \\
(=20+30) \text { day } \\
\text { from } 1 \text { Navasard } \\
(20 \text { Hori }) .\end{array}$ \\
\hline
\end{tabular}




\begin{tabular}{|c|c|c|c|c|}
\hline $\begin{array}{l}\text { One } \\
\text { month (= } \\
30 \text { days) }\end{array}$ & Bagavan & $\begin{array}{l}\text { Fasting time, } \\
\text { preparation for the } \\
\text { Baptism }\end{array}$ & 829 & \\
\hline $\begin{array}{l}\text { When one } \\
\text { month } \\
\text { was spent }\end{array}$ & Bagavan & $\begin{array}{l}\text { Baptism of the } \\
\text { king, his family, } \\
\text { and many people in } \\
\text { Euphrates }\end{array}$ & $\begin{array}{l}832- \\
834\end{array}$ & $\begin{array}{l}\text { On the } 80^{\text {th }} \text { day } \\
\text { from } 1 \text { Navasard } \\
\text { (20 Sahmi). }\end{array}$ \\
\hline $\begin{array}{l}\text { Seven } \\
\text { days "af- } \\
\text { ter this" }\end{array}$ & Bagavan & $\begin{array}{l}\text { Gregory continues } \\
\text { to baptise people }\end{array}$ & 835 & $\begin{array}{l}\text { From } 21 \text { to } 27 \\
\text { Sahmi. }\end{array}$ \\
\hline
\end{tabular}

The Agathangelos obviously describes a liturgical cycle but, as a whole, this cycle is not preserved in any existing calendar. Only the feast of St John the Baptist and St Athenogenes on the New Year (1 Navasard) is preserved as established by St Gregory. ${ }^{218}$ However, in the same text of the Agathangelos, another date of this feast is prescribed, also with the authority of St Gregory, on 7 Sahmi (Aa 815). This feast is also preserved in the Armenian calendar. ${ }^{219}$ Two competing liturgical traditions concerning the saints whose relics were brought by St Gregory from Cappadocia after his consecration are thus included in Agathangelos' account side-by-side.

\section{Two Remnants of Earlier Commemorations of St Gregory: 20 Sahmi and 20 Horri}

The feast on $20 \mathrm{Sahmi}$ is also present in the later Armenian calendar although without its seven-day afterfeast. Its original meaning, a commemoration of the Baptism in Bagavan, was translated (if Peeters and van Esbroeck are right) ca 500, to 10/11 K'ałoc'. Nevertheless, 20 Sahmi became the day of commemoration of two virgins among those with Rhipsime, Nanē (St Nino of Georgia) and Manē. The latter, called Mani in other sources, lived as a hermit and was found by St Gregory the Illuminator just before her death. She was then buried by him in her cave, the very cave in which St Gregory himself also ended his days as

(218) G. BAyAn, Le Synaxaire arménien de Ter Israel. I. Mois de Navasard (Paris, 1910) (PO, 5, 3; N 23) [repr. Turnhout, 2003] 355[11]-357[13]; here a feast of St John the Baptist only, without Athenogenes.

(219) G. Bayan, Le Synaxaire arménien de Ter Israel. III. Mois de Sahmi (Paris, 1927) (PO, 15, 3) 314[378]-215[379]; St John the Baptist together with Athenogenes. 
a hermit. The earliest document concerning Mani is Vk, the Karshuni recension of the Agathangelos. The legend about Mani is a part of a legend about the first discovery of the relics of St Gregory. ${ }^{220}$ Thus, the commemoration of Mani on 20 Sahmi is an indirect commemoration of St Gregory (that is, the discovery of his relics, the day of his death being unknown in the same manner as the day of the death of the biblical Moses). ${ }^{221}$ The chronology of the Armenian Agathangelos explains the reason for the original choice of this date.

The Armenian calendar preserves the date 20 Hori as the commemoration day of the apostle of Caucasian Albania, Elisæus (Ełišēe), ${ }^{222}$ whose biography (his death in a pit of poisonous reptiles) is suspiciously similar to that of St Gregory. And, according to the $\mathbf{V}$ family of Agathangelos, it was Gregory who baptised the Albanians along with the Armenians. Such a rededication of an earlier Armenian feast of the St Gregory cycle to the legendary disciple of apostle Thaddeus is obviously an Albanian tradition intended to demonstrate the apostolic origin of the Albanian Church and, thus, her right to autocephaly. After the absorption of the Albanian Church by the Armenian one (ca 705), this feast was preserved because the place of the earlier Armenian feast on 20 Hori was free.

We have to conclude that most of the dates specified in the above chronology of Aa are important feasts in the later Armenian tradition. Moreover, these feasts preserve explicit or implicit indications of a connexion to the cycle of St Gregory the Illuminator and the Baptism of four nations in the Caucasus. Our chronology thus appears to represent a liturgical cycle that did exist somewhere, although it was no longer comprehensible to the editor of Aa, who added an alternative feast of John the Baptist and Athenogenes on 7 Sahmi. It would indeed be difficult to imagine any non-liturgical meaning for such a detailed chronology in a hagiographical text

(220) See, for details, van EsBroeck 1971, 390-395.

(221) In the fixed Armenian calendar (since the thirteenth century) the commemoration of St Gregory on 30 September is rendered as 21 Sahmi. This feast was borrowed in Byzantium with no relation to the earlier Armenian traditions (s. above).

(222) G. BAYAN, Le Synaxaire arménien de Ter Israel. II. Mois de Hori (Paris, 1910) [repr.: Turnhout, 2003] (PO 6, 2; N 27) 302[334]-304[336], 307[339]308[340]. 


\section{The Pentecost after the Dormition of the Theotokos}

Having established that our liturgical cycle in Aa presents some liturgical realities, we have to reexamine its coverage of the first fifty days from 1 Navasard to 20 Sahmi. The current commemoration of St Mani on 20 Sahmi is a remnant of an earlier feast of the discovery of the relics of St Gregory. But what is the importance of 1 Navasard itself? Why was it used as the starting point of a pentecontad cycle?

Normally, the starting point for all the calendric pentecontads is the date of Easter. It is a Jewish custom from the Second Temple period presented in such Jewish calendars as those of the Temple Scroll or the Songs of the Sacrifice of Sabbath. Up to the early fifth century, the second Pentecost after Easter was still celebrated throughout the Christian world (the movable feast of the Holy Apostles in the Constantinopolitan rite and the Syrian Jacobite rite of Antioch up to the middle of the sixth century and, in the Syrian Jacobite rite of Tikrit, up to the eighteenth century), and it persisted up to the second millennium as the Agat'enagoba (St Athenogenes' feast) in the Georgian rite and is currently celebrated as the Vardavar in the Armenian rite. A more elaborated system of the pentecontad periods covering the whole year is still traceable in the Syrian Nestorian calendar.

When, in the middle of the fifth century, the feast of the Dormition was introduced, its liturgy was patterned after Easter. Around 500, it became the starting point of a new series of pentecontads. In the Jerusalem rite, there were two Dormition pentecontads which were accepted by the rite of Constantinople, too, as well as by some Syrian anti-Chalcedonian traditions: from 15 August to 3 October and from 3 October to 21 November. The feasts of 3 October (Dionysius the Areopagite as an eyewitness of the Dormition and the open heavens) and 21 November (Presentation of the Theotokos) go back to the liturgical institutions of the patriarchate of Jerusalem $c a 500.223$

Are the two commemorations of St Gregory the Illuminator on 20 Sahmi and 30 September Armenian analogues of these Jerusalem pentecontads?

The feast of the Dormition of the Theotokos was introduced as a date in the Julian calendar having no constant equivalent in the Old Armenian calendar. 30 September is the fiftieth day after 12 August, the eve of one of the known Dormition dates, 13 August. It is preserved as the first day of the Dormition cycle in the first millennium Georgian

(223) Lourié 2010, 192-192. 
rite, which was probably shared by the Armenians (implying $15 \mathrm{Au}$ gust as the day of the Dormition itself). In the Syriac "Dormition in Six Books" (Transitus S 3), however, this is the very date of the Dormition itself; this source may reflect the calendar shared by the Armenians in the late fifth century, the time of the reconstruction of the Etchmiadzin cathedral. The chronology of this Transitus implies that 12 August is the date of the gathering of the apostles.

If, in the 480s, the Etchmiadzin cathedral was consecrated on the eve of the Dormition feast (the Armenian tradition insists on this sequence of the Šołakat'-encaenia and the Dormition feast), the date of the consecration was, most likely, 12 August, corresponding to the Dormition on 13 August. The further shift to 14 and 15 August is a sixth-century or even later development. It would be only natural if a new cult in the principal cathedral of Armenia reused the vision of St Gregory the Illuminator that was related to the same cathedral. Unlike Dionysius the Areopagite, St Gregory was not an eyewitness to the Dormition, but he was the seer of the heavenly temple represented by the cathedral now rededicated to the Dormition. Thus, it was in the style of the epoch to connect the feast and its witness through a fifty-day cycle.

It is not clear so far, however, how this cycle is connected to the pentecontad reported in the Agathangelos for 1 Navasard to 20 Sahmi. To answer this question, we have to turn to the very beginning of the Dormition feast in the Armenian Church.

\section{The New Year on 1 Navasard and the Dormition of the Theotokos}

Unlike the previous ecumenical councils, whose opening dates were chosen with a symbolic proximity to Pentecost, the Second Council of Ephesus (449) opened on 8 August, a date having no relation to this feast. I have argued elsewhere that this date was chosen in relation to the earliest Dormition cycle (from 7 to 9 August), where it corresponds to the gathering of apostles in Sion. This council seems to be the first occasion when a recent Palestinian feast was accepted by the Churches throughout the whole universe. ${ }^{224}$ This council was subsequently called "latrocinium" in Rome but certainly not in Armenia. Two bishops from Roman Armenia were presented among the fathers of the council. ${ }^{225}$

(224) LOURIÉ 2010, 180-183.

(225) John of Sebastia in First Armenia ( $\mathrm{Nr} 10$ in the list) and Acacius of Ariarathia in Second Armenia presenting Constantius of Melitene, who was 
According to the Old Armenian calendar, 7 August 449 (the first day of the Dormition feast) was 2 Navasard and, correspondingly, 1 Navasard was 6 August, the eve of the Dormition. Thus, in 449, the pentecontad from the eve of the Dormition coincided with the Agathangelos' pentecontad from 1 Navasard to 20 Sahmi (this is true for the years from 448 to 451 ). ${ }^{226}$ In this way the Dormition feast arrived in the Armenian Church accompanied by a remarkable synchronism with the earlier cycle of St Gregory the Illuminator (from 1 Navasard to 20 Sahmi). This cycle was certainly taken into account during the rededication of the Etchmiadzin cathedral in the 480s, when the date of the Dormition feast shifted to 13 August. The link between the Dormition and an important feast related to St Gregory on the eve of this feast was preserved in conformity with Baumstark's second law. A new Gregory-related feast appeared on 12 August. Thus, the calendar of the Armenian Church preserves one feast established by St Gregory the Illuminator on 1 Navasard and another feast related to him on the eve of the Dormition.

The later cycle related to the Dormition became a more important commemoration of St Gregory, and St Gregory's commemoration on 20 Sahmi thus lost most of its importance (allowing a substitution of Gregory's name by those of two saints related to him, Nino of Georgia and Mari), but a new commemoration of St Gregory appeared on 30 September. However, its direct connexion to the Šotakat'-encaenia feast on the eve of the Dormition was necessarily lost when the Armenian Church adopted 15 August as the date of the Dormition.

\section{Abbreviations}

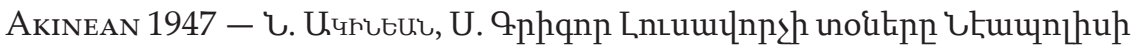

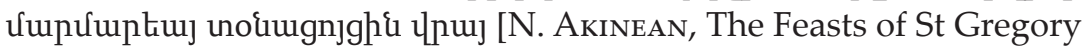
the Illuminator in the Marble Calendar of Naples], Zuinitu Uúunptuu] [Handes Amsoreay = Monthly Magazine] 21 (1947) cols. 600-614.

absent (Nr 18): S. G. F. Perry, The Second Synod of Ephesus, together with Certain Extracts Relating to It, From Syriac Mss. preserved in the British Museum. English Version (Dartford, 1881) 15-16.

(226) It is interesting that 7 August 449 was Sunday and 6 August was Saturday. Has this fact anything to do with the Armenian tradition of celebrating the Dormition only on Sunday (nearest to its fixed date August 15) and the Šłakat'-encaenia only on the previous Saturday? 
Greenwood 2006 - T. Greenwood, The discovery of the relics of St Grigor and the development of Armenian tradition in ninth-century Byzantium, in: E. M. Jefrreys (ed.), Byzantine Style, Religion and Civilization: In Honour of Sir Steven Runciman (Cambridge, 2006) 177-191.

JANIN 1969 - R. JANIN, La géographie ecclésiastique de l'Empire byzantin. III. Les églises et les monastères (Paris, ${ }^{21969)}$.

Loseva 2009 - О. В. Лосева, Жития русских святых в составе древнерусских прологов XII - первой трети XV веков [The Lives of Russian Saints within the Old Russian Prologoi of the twelfth - first third of the fifteenth centuries] (Moscow, 2009) (Studia historica).

Lourié 2007 - B. Lourié, L'Histoire Euthymiaque : l'œuvre du patriarche Euthymios/Euphemos de Constantinople (490-496, +515), Warszawskie Studia Teologiczne XX/2 (2007) 189-221.

Lourié 2010 - B. LouriÉ, Peter the Iberian and Dionysius the Areopagite: Honigmann-van Esbroeck's Thesis Revisited, Scr 6 (2010) 143-213.

Moldovan 2000 - A. М. Молдован, Житие Андрея Юродивого в славянской письменности [The Life of Andrew the Salos in the Slavic Literatures] (Moscow, 2000).

Peeters 1942 - P. Peeters, S. Grégoire l'Illuminateur dans le calendrier lapidaire de Naples, AB 60 (1942) 91-130.

Pliukhanova 2008 - М. Б. Плюханова, В поисках исторического источника (Службы Покрову) [In Search of the Historical Source (of the Service to Pokrov)], in: M. Di Salvo, G. Moracci, G. Siedina (a cura di), Nel mondo degli Slavi. Incontri e dialoghi tra culture. Studi in onore di Giovanna Brogi Bercoff. Vol. II (Firenze, 2008) (Biblioteca di studi slavistici, 8) 437-447.

RYdÉn 1995 - L. Rydén, The Life of St Andrew the Fool, 2 vols. (Uppsala, 1995) (Acta Universitatis Upsaliensis. Studia Byzantina Upsaliensia, 4), 2 vols.

Spassкij 1898 - Архим. Сергий [СПасский], Святый Андрей Христа ради юродивый и праздник Покрова Пресвятыя Богородицы [Saint Andrew the Fool for Christ and the Feast of the Intercession of the Theotokos], Странник 3 (1898) 3-33, 193-214, 393-425, 605-652 [quoted according to the republication: Жизнь и деяния св. Отия нашего Андрея, юродивого Христа ради. Вступительная статья, перевод с греческого языка и комментарии Е. В. Желтовой. С приложением сочинения архиеп. Сергия (Спасского) «Святой Андрей, Христа ради юродивый, и праздник Покрова Пресвятой Богородицы» (St Petersburg, 2007) (Библиотека христианской мысли. Источники) 180-314], especially part «Б. Место и время установления праздника Покрова Пресвятой Богородицы [В. The Place and the Time 
of Establishment of the Feast of Pokrov of the Most Holy Theotokos]», p. 233-266.

Symeon Logothetos - S. WAhlgren, Symeonis Magistri et Logothetae Chronicon (Berolini-Novi Eboraci, 2006) (CFHB, Ser. Berolinensis, XLIV/1).

Synaxarium CP - H. Delehaye (ed.), Synaxarium ecclesiae Constantinopolitanae e codice Sirmondiano nunc Berolinensi adiectis synaxariis selectis (Brussels, 1902) (AASS, Propylaeum ad AASS Novembris).

van Esbroeck 1971 - M. van Esbroeck, Les témoignages littéraires sur les sépultures de saint Grégoire 1'Illuminateur, AB 89 (1971) 387-417.

Wortley 1971 - J. Wortley, Hagia Skepê and Pokrov Bogoroditsi: A Curious Coincidence, $A B 89$ (1971) 149-154 [reprint: IDEM, Studies on the Cult of Relics in Byzantium up to 1204 (Aldershot etc., 2009) (Variorum Collected Studies Series, CS 935) Ch. XII].

Wortley 2005 - J. Wortley, The Marian relics in Constantinople, Greek, Roman, and Byzantine Studies 45 (2005) 171-187 [repr.: IDEM, Studies on the Cult of Relics in Byzantium..., ch. XI].

Yusov 2009 - И. Е. Юсов, Гимнография праздника Покрова Пресвятой Богородиць как источник изучения истории русского литературного языкa [The Hymnography of the Feast of Pokrov of the Most Holy Theotokos as a Source for the Study of the History of the Russian Literary Language]. Диссертация на соискание ученой степени кандидата филологических наук (Moscow, 2009) (unpublished thesis).

ВМЧ - Памятники славяно-русской письменности, изданные Археографическою комиссиею. I. Великие минеи четии. Октябрь, дни 1-3 [Monuments of Slavic-Russian Literature Published by the Archeographical Commission. I. The Great Menologion. October, Days 1-3] (St Petersburg, 1870).

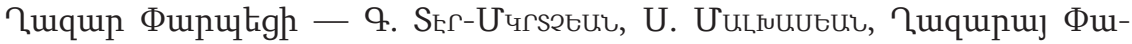

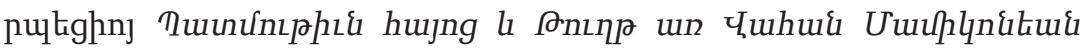

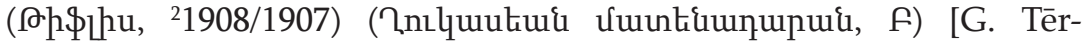
Mkrtč'ean, S. Malxasean, Eazar P'arpec'i's History of Armenia and the Epistle to Vahan Mamikonean (Tiflis, 1908/1907 <different dates on the cover and on the front page, respectively $>$ (Łukasean Library, 2) = reprint of the 1904 critical edition]. 


\section{SUMMARY}

Part One: Byzantino-Slavica

\subsection{Introduction}

1.2. The Theoretical Impossibility of the "Russian" Approach

1.3. Wortley's Hypothesis

1.4. The Christian Community in Kiev in the Time of Patriarch Euthymius

1.5. A South Slavic Alternative

1.6. The Original Meaning of the Feast of Pokrov According to Pachomius Logothetos

1.7. BHG 1136d: a Greek Homily on Pokrov

1.7.1. The Greek Original and Its Pseudepigraphic Authorship

1.7.2. Liturgical Setting and Contents: Pokrov Vigil

1.7.3. Author: Patriarch Euthymius

1.8. The Prolog sermon on Pokrov

\subsubsection{Contents}

1.8.2. Relation to the Life of Andrew the Salos

1.8.3. Author

1.9. Conclusion to the Byzantino-Russian Dossier

Part Two: Armeno-Byzantina

2.1. Introduction

2.2. The Discovery of the Relics of St Gregory during the Patriarchate of Photius

\subsubsection{Historical Context}

2.2.2. Precise Place: $\tau \dot{\alpha}$ K $\alpha \varrho \iota \alpha v o \tilde{v}$ monastery near Blachernae

Note 1: van Esbroeck's identification of the monastery $\tau \dot{\alpha}$ Ka@ı$\alpha$ vov with the monastery of Staurakios

2.2.3. Date: between 862 and 867

2.2.4. The Date of the Liturgical Commemoration

2.3. Gregory the Illuminator and Isaac the Parthian as the Saints of the Macedonian Dynasty

2.3.1. Isaac the Parthian in Photius' Cult of St Gregory the Illuminator 2.3.2. St Gregory the Illuminator in the Cult of St Patriarch Stephen 2.3.3. The Cult of St Gregory the Illuminator under Patriarch Nicholas Mystikos

2.3.4. An Alternative to the Vision of St Sahak: the Apocalypse of Andrew the Salos

2.4. The Veneration of "Pokrov" before the Feast of Pokrov

2.4.1. Photius, 860: the Discovery of "Pokrov"

2.4.2. When "Pokrov" Becomes "Omophorion/Maphorion"

2.4.3. A Secondary "Pokrov" Cult: The Maphorion of St Theophano 
2.4.4. How "Pokrov" Becomes "Omophorion/Maphorion"

2.4.5. The Bishop's "Maphorion" of St Gregory the Illuminator

2.4.6. Why "Pokrov" Becomes "Omophorion/Maphorion"

2.5. Conclusion to the Armeno-Byzantine Dossier

Note 2: A Tentative Reconstruction of a Liturgical Cycle Possibly

Related to the Vision of St Andrew within the Life of Andrew the Salos

Part Three: the Feast of Pokrov within the Cycle of St Gregory the ILLUMINATOR

3.1. The Marian Relics and the Wives of Leo the Wise

3.2. The Symbolic Nature of the Date 1 October

3.3. The Autumn Commemorations of St Gregory the Illuminator and His Companions in Constantinople

3.4. The Choice of 1 October for the Pokrov Feast

Excursus: St Gregory the Illuminator's Feast on 30 September

1. Peeters' Hypothesis

2. The Dormition of the Theotokos and the Dedication of the Cathedral of Etchmiadzin

3. The Dates of the Baptism of Armenia in the Agathangelos

4. Two Remnants of Earlier Commemorations of St Gregory:

20 Sahmi and 20 Hori

5. The Pentecost after the Dormition of the Theotokos

6. The New Year on 1 Navasard and the Dormition of the Theotokos 